\section{Pacific Northwest}

National Laboratory

Operated by Battelle for the

U.S. Department of Energy

\title{
Gas Generation from K East Basin Sludges - Series II Testing
}

\author{
S. A. Bryan \\ K. L. Silvers \\ C. H. Delegard \\ K. L. Silvers \\ A. J. Schmidt \\ S. R. Gano \\ R. L. Sell \\ B. M. Thornton
}

March 2001

Prepared for the U.S. Department of Energy under Contract DE-AC06-76RL01830 


\title{
DISCLAIMER
}

This report was prepared as an account of work sponsored by an agency of the United States Government. Neither the United States Government nor any agency thereof, nor Battelle Memorial Institute, nor any of their employees, makes any warranty, express or implied, or assumes any legal liability or responsibility for the accuracy, completeness, or usefulness of any information, apparatus, product, or process disclosed, or represents that its use would not infringe privately owned rights. Reference herein to any specific commercial product, process, or service by trade name, trademark, manufacturer, or otherwise does not necessarily constitute or imply its endorsement, recommendation, or favoring by the United States Government or any agency thereof, or Battelle Memorial Institute. The views and opinions of authors expressed herein do not necessarily state or reflect those of the United States Government or any agency thereof.

\author{
PACIFIC NORTHWEST NATIONAL LABORATORY \\ operated by \\ BATTELLE \\ for the \\ UNITED STATES DEPARTMENT OF ENERGY \\ under Contract DE-AC05-76RL01830
}

Printed in the United States of America
Available to DOE and DOE contractors from the Office of Scientific and Technical Information,
P.O. Box 62, Oak Ridge, TN 37831-0062;
ph: (865) 576-8401
fax: $(865)$ 576-5728
email: reports@adonis.osti.gov

\begin{abstract}
Available to the public from the National Technical Information Service, U.S. Department of Commerce, 5285 Port Royal Rd., Springfield, VA 22161 ph: (800) 553-6847 fax: $(703) 605-6900$ email: orders@ntis.fedworld.gov online ordering: http://www.ntis.gov/ordering.htm
\end{abstract}

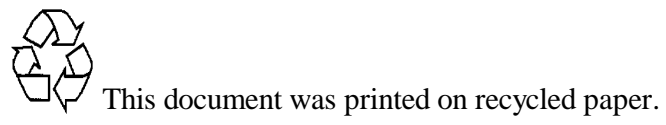


PNNL-13446

\title{
Gas Generation from K East Basin Sludges - Series II Testing
}

\author{
S. A. Bryan \\ C. H. Delegard \\ A. J. Schmidt \\ R. L. Sell \\ K. L. Silvers \\ S. R. Gano \\ B. M. Thornton
}

March 2001

Prepared for Fluor Hanford, Inc.

Work Supported by

the U.S. Department of Energy

under Contract DE-AC06-76RL01830

Pacific Northwest National Laboratory

Richland, Washington 99352 


\section{Summary and Conclusions}

The path forward for the management of Hanford K Basin sludge calls for it to be packaged, shipped, and stored at $\mathrm{T}$ Plant until final processing at a future date. An important consideration for the design and cost of retrieval, transportation, and storage systems is the potential for heat and gas generation through oxidation reactions between uranium metal and water. This report, the second in a series [Series II], describes work performed at the Pacific Northwest National Laboratory to examine the gas generation behavior of $\mathrm{K}$ Basin sludge materials by using actual $\mathrm{K}$ East (KE) Basin floor, pit, and canister sludge. Mixed and unmixed and fractionated KE canister sludge was tested, along with floor and pit sludge from areas in the KE Basin not previously sampled. The first report in this series [Series I] (Delegard et al. 2000) focused on gas generation from KE floor and canister sludge collected using a consolidated sampling technique. The third report [Series III] will present results of gas generation testing of irradiated uranium fuel fragments with and without sludge addition. The work is being conducted under the direction of the Spent Nuclear Fuel Sludge Handling Project managed by Fluor Hanford, Inc., and in accordance with the data quality objectives (Makenas 2000) and the sampling and analysis plan (Baker et al. 2000).

The overall goal for this testing was to collect gas generation rate and composition data under known conditions to better understand the quantity and reactivity of the metallic uranium present in the K Basin sludge. Specific objectives for Series II included:

1. Evaluate the reactivity and determine the quantity of uranium metal present in each sludge type.

2. Provide gas generation data that can be used as design input into sludge transportation and storage systems.

3. Determine whether the reactivity of KE canister sludge is affected by aggressive agitation and sieving.

4. Obtain data on the expected uranium metal fraction and particle size in KE canister sludge to provide a basis for selecting values to be used in analyses.

5. Determine the reactivity of the single-pull (core) KE floor and pit sludge samples.

6. Evaluate the gas generation behavior of $\mathrm{KE}$ floor sludge consisting primarily of organic ion exchange material.

7. Evaluate the residual reactivity of archived KE canister sludge collected in 1996 that initially displayed a significant gas generation rate.

8. Compare the gas generation behavior of sludge collected by two different sampling techniques from the same general location.

Tests to meet these objectives were conducted from July through September 2000. The major conclusions are given below:

- Overall, the sludge samples evaluated in the Series II tests were relatively benign and unreactive, as demonstrated by their low gas generation rates. In comparison, the KE canister and floor sludge tested in Series I exhibited a higher uranium metal content than similar sludge tested in Series II. Because the sludge material used in Series II was stored for a longer period of time at slightly elevated temperatures, the Series I results more accurately reflect the uranium metal content of the sludge in the KE Basin. 
- For certain sludge samples in Series II, use of fission product gas $(\mathrm{Kr}$ and $\mathrm{Xe})$ release data resulted in a higher and more accurate estimation of the uranium metal content in comparison with the corrosion gas $\left(\mathrm{H}_{2}, \mathrm{O}_{2}, \mathrm{~N}_{2}\right)$ data.

- Canister sludge that had been stored wet in a shielded facility for 14 months at $\sim 32^{\circ} \mathrm{C}$, after sample collection, contained about $0.56 \mathrm{wt} \%$ uranium metal (based on analysis of the release of fission product gases).

- Testing with canister sludge (stored for 14 months at $32^{\circ} \mathrm{C}$ ) showed that very little metallic uranium is present in the material containing particles less than $500 \mu \mathrm{m}$.

- Aggressive agitation and sieving of canister sludge resulted in a 9X increase in the quantity of uranium metal that reacted over the test period (i.e., without agitation, $0.065 \mathrm{wt} \%$ of sample reacted; with agitation, $0.56 \mathrm{wt} \%$ of sample reacted.)

- The single-pull core floor and pit sludge samples displayed very low chemical reactivity, provided little gas generation, and are estimated to contain 0.0013 to $0.027 \mathrm{wt} \%$ metallic uranium (settled sludge basis).

- Sludge that consisted primarily of organic ion exchange resin beads generated very little gas even after 950 hours at temperatures of $90^{\circ} \mathrm{C}$ and $95^{\circ} \mathrm{C}$. It is estimated that this material contains about $0.026 \mathrm{wt} \%$ uranium metal.

- Archived canister sludge from the 1996 sampling campaign no longer demonstrated significant reactivity. Based on analysis of the release of fission product gases, this sludge was estimated to contain about $0.9 \mathrm{wt} \%$ uranium metal (settled sludge basis).

Consistent with the data quality objectives (Makenas 2000) and the sampling and analysis plan (Baker et al. 2000), this series of tests provides base supporting information for the design and evaluation of the systems being developed to transport and store the K Basin sludge at $\mathrm{T}$ Plant. The tests and further interpretation of the results are summarized below.

\section{Test Materials and Description}

The sludge materials used in the Series II tests reported here were collected from the KE Basin using single-pull sampling techniques. Ten tests are described in this report. Two other tests were also included in this series (consolidated canister sludge and a fuel fragment), but these tests are ongoing and will be discussed in the Series III report.

Four gas generation tests were conducted using the KE canister sludge sample, KC-1, which contained $37 \mathrm{wt} \%$ (settled sludge basis) total uranium. This sample, collected in April 1999, came from a single canister containing highly damaged fuel. For the testing, an agitated (highly mixed) and an unagitated aliquot of $\mathrm{KC}-1$ were used to investigate whether $\mathrm{K}$ Basin retrieval operations have the potential to "activate" uranium metal in the sludge. A portion of $\mathrm{KC}-1$ was sieved to separate particles greater than, or "plus," $500 \mu \mathrm{m}$ (P500) from particles less than, or "minus," $500 \mu \mathrm{m}$ (M500). This separation was made to mimic the separation operations that are planned during the retrieval of certain K Basin sludge types and to gain a better understanding of how uranium metal is distributed in the sludge.

Four other tests were conducted using samples collected from the KE floor and pits between December 1998 and June 1999: main basin floor (FE-1), North Loadout Pit (FE-3), Weasel Pit (FE-5), and Tech View Pit and Dummy Elevator Pit (FE-4/6). These tests were conducted to show how gas generation behavior varies as a function of sludge source location, and to provide further confirmation of the low reactivity of the KE floor and pit sludge. With the exception of FE-1, these tests were conducted using 
sludge from areas not sampled during the $1995 \mathrm{KE}$ floor and Weasel Pit sampling campaign (Makenas et al. 1996).

Series II also included a test with a sample collected from the KE floor that was mainly composed of organic ion exchange resin beads (KC-6). This type of sludge is unique, and the test was conducted to gain an understanding of the stability of organic ion exchange resin under T Plant storage conditions. The last test was conducted to determine if the highly reactive sludge, 96-06, collected during the 1996 KE canister sampling campaign (Makenas et al. 1997), still exhibited reactivity and gas generation potential.

For the testing, 14- to 27-gram sludge samples were placed into $60-\mathrm{ml}$ reaction vessels. The vessels were heated to maintain selected temperatures; the gas pressure was monitored continuously; and gas samples were collected twice from each vessel and analyzed via mass spectrometry. The testing was initiated on July 24, 2000, and continued for approximately 950 hours to September 4, 2000. The tests were conducted at elevated temperatures (ranging from $60^{\circ} \mathrm{C}$ to $90^{\circ} \mathrm{C}$ ) to accelerate the reactions and provide conclusive gas generation data within a reasonable testing period. The temperature in all test vessels was increased to $95^{\circ} \mathrm{C}$ for a period at the end of the tests to force completion of the reactions. The table below shows the test matrix and the estimated uranium metal content for each sample as determined from the gas generation testing. The technique used to estimate uranium metal content (corrosion gas generation or fission product gas release) is also noted in the table.

Experimental Matrix for Series II Gas Generation Tests and Uranium Metal Estimates

\begin{tabular}{|c|c|c|c|c|c|c|}
\hline \multirow[b]{2}{*}{ Test Description } & \multicolumn{2}{|c|}{ Sludge Sample Fraction } & \multicolumn{2}{|c|}{ Test Temp., ${ }^{\circ} \mathrm{C}$} & \multicolumn{2}{|c|}{ Estimated Uranium Metal Content } \\
\hline & Sample ID & $\begin{array}{l}\text { Settled } \\
\text { Sludge, } g\end{array}$ & $\begin{array}{c}\text { Start } \\
\sim 300 \mathrm{hr}\end{array}$ & $\begin{array}{c}\text { Final } \\
\sim 650 \mathrm{hr}\end{array}$ & $\begin{array}{c}\text { Wt \% U Metal } \\
\text { (Settled Sludge Basis) }\end{array}$ & $\begin{array}{l}\text { Estimation } \\
\text { Technique }\end{array}$ \\
\hline \multicolumn{7}{|c|}{ KE Canister Sludge (Consolidated Sampler Used in Single-Pull Mode) } \\
\hline Unmixed KC-1 & KC-1 (whole) & 23.8 & 60 & 95 & 0.065 & Fission Product Gas \\
\hline Mixed KC-1 & KC-1 (whole) & 25.6 & 60 & 95 & 0.56 & Fission Product Gas \\
\hline U Metal in KC-1 & Plus $500 \mu \mathrm{m}$ & 14.2 & 80 & 95 & 3.7 & Fission Product Gas \\
\hline U Metal in KC-1 & Minus $500 \mu \mathrm{m}$ & 22.3 & 80 & 95 & 0.14 & Fission Product Gas \\
\hline \multicolumn{7}{|c|}{ Single-Pull Core KE Floor and Pit Sludge Samples } \\
\hline Main Floor (FE-1) & FE-1 (whole) & 27.0 & 90 & 95 & 0.022 & Fission Product Gas \\
\hline $\begin{array}{l}\text { North Loadout Pit } \\
\text { (FE-3) }\end{array}$ & FE-3 (whole) & 21.2 & 90 & 95 & 0.0013 & Corrosion Gas \\
\hline Weasel Pit (FE-5) & FE-5 (whole) & 20.7 & 90 & 95 & 0.027 & Fission Product Gas \\
\hline $\begin{array}{l}\text { Dummy Elevator } \\
\text { and Tech View Pit } \\
\text { (FE-4 + FE-6) }\end{array}$ & $\begin{array}{l}\text { FE-4 }(63 \%)+ \\
\text { FE-6 }(37 \%)\end{array}$ & $\begin{array}{c}16.1 \\
(10.2 / 5.9)\end{array}$ & 90 & 95 & 0.0052 & Corrosion Gas \\
\hline \multicolumn{7}{|c|}{ Other Tests } \\
\hline $\begin{array}{l}\text { Organic Ion } \\
\text { Exchange Resin } \\
\text { Sludge }\end{array}$ & KC-6 (whole) & 19.1 & 90 & 95 & 0.026 & Corrosion Gas \\
\hline $\begin{array}{l}1996 \text { KE Canister } \\
\text { Sludge }\end{array}$ & $96-06$ & 19.5 & 80 & 95 & 0.90 & Fission Product Gas \\
\hline
\end{tabular}




\section{Gas Generation Testing}

Gas production observed in the Series II tests with KE Basin sludge was generally lower than observed in similar Series I studies of KE Basin canister and floor sludges (Delegard et al. 2000). The lower gas generation rates can partially be attributed to the longer storage periods at hot cell temperatures experienced by the Series II sludge samples. All tests in Series II (conducted with sludge from samples $\mathrm{KC}-1$, FE-1, FE-3, FE-5, FE-4/6, KC-6, and 96-06) produced $\mathrm{CO}_{2}$ as the predominant gas product with lower concentrations of $\mathrm{H}_{2}$, except the KC-1 P500 test, which produced predominantly $\mathrm{H}_{2}$ gas with lower $\mathrm{CO}_{2}$ concentrations. Other gases released or produced were $\mathrm{Xe}, \mathrm{Kr}$, and hydrocarbons (methane, ethane, and higher hydrocarbons). Trace amounts of $\mathrm{O}_{2}$ and $\mathrm{N}_{2}$ present from atmospheric contamination also were consumed in each test. Similar gas generation and consumption was observed in the Series I tests and in gas collection tests from $\mathrm{KE}$ canister sludge (Makenas et al. 1997). The release of $\mathrm{CO}_{2}$ in these tests may be due to the reaction of schoepite with calcite to form becquerelite and $\mathrm{CO}_{2}$. However, in none of the 10 tests were $\mathrm{pHs}$ significantly lowered by reaction. Lowered $\mathrm{pHs}$ would be expected unless strong $\mathrm{pH}$ buffering was occurring in these sludges.

In the Series I tests, the release of $\mathrm{H}_{2}$ produced by the reaction of uranium metal with water was shown to lag the release of $\mathrm{Xe}$ (and $\mathrm{Kr}$ ) fission product gas in small-scale vessel tests with the plus $250-\mu \mathrm{m}$ consolidated canister sludge composite (KC-2/3 P250). This lag was attributed to the uptake of hydrogen by uranium metal to form the reactive intermediate $\mathrm{UH}_{3}$. In the present report, data from these Series I experiments were interpreted further to determine the true induction times to onset of the hydridemediated anoxic corrosion of uranium by water. In agreement with results from tests reported in the technical literature, essentially zero induction time to onset of corrosion was found by analysis of Xe release rates at $80^{\circ} \mathrm{C}$, as opposed to about 27 hours as determined by $\mathrm{H}_{2}$ gas release. Uranium corrosion rates caused by reaction with water were determined by Xe release corrected by the contributions due to reactions with $\mathrm{O}_{2}$ and $\mathrm{N}_{2}$. In agreement with previous findings, the rates follow the Arrhenius temperature dependence with a $15.8 \mathrm{kcal} / \mathrm{mole}$ activation energy.

Further interpretation of data from the KC-2/3 P250 and other Series I tests confirmed the agreement between the uranium concentration predicted based on the $\mathrm{H}_{2}, \mathrm{O}_{2}$, and $\mathrm{N}_{2}$ gases involved in corrosion reactions and the $\mathrm{Kr}$ and $\mathrm{Xe}$ fission product gases evolved. ${ }^{\text {(a) }}$ The agreement was within a factor of 5 down to about $0.01 \mathrm{wt} \%$ uranium in the settled sludge, but deviated below that concentration. Similar comparisons for the results from the Series II tests showed significantly lower uranium concentrations as measured by $\mathrm{H}_{2}, \mathrm{O}_{2}$, and $\mathrm{N}_{2}$ than by $\mathrm{Kr}$ and $\mathrm{Xe}$. The likely uptake of $\mathrm{H}_{2}$ by uranium metal to form hydrides and the possible reaction of $\mathrm{H}_{2}$ with uranium(VI) compounds (such as schoepite) to form chemically reduced $\mathrm{U}_{3} \mathrm{O}_{8}$ or $\mathrm{UO}_{2}$ cause the uranium metal concentrations determined by these measurements from corrosion gases to be underestimated. Therefore, estimates of uranium metal concentration based on amounts of fission product gas release are thought to be more reliable and provide a better upper bound when the two estimation techniques vary. It is recognized that uranium concentrations determined by fission product gas release have intrinsic uncertainty because burnup is not known for the uranium in the sludge.

The agitation/aeration tests with the canister sludge, $\mathrm{KC}-1$ [(KC-1 Un (unmixed) and KC-1 Mix (aggressively agitated)], showed that uranium metal corrosion was enhanced by the agitation/aeration treatment. Though the mixed sludge evidently consumed amounts of $\mathrm{O}_{2}$ and $\mathrm{N}_{2}$ similar to those of the

(a) Assuming $2900 \mathrm{MWd} / \mathrm{TeU}$ irradiation. 
unmixed sludge, about nine times more corrosion occurred in the mixed test (KC-1 Mix), as shown by fission product gas analyses. Thus, the mixing likely acted to increase corrosion by attrition and exposure of fresh uranium metal surface stripped of protective oxide films. The uranium metal concentration inferred from the $\mathrm{KC}-1 \mathrm{Mix}$ test is about $0.56 \mathrm{wt} \%$. In comparison, canister sludge sample $\mathrm{KC}-2 / 3$ in Series I was estimated to contain $\sim 1.9 \mathrm{wt} \%$ metallic uranium (settled sludge basis). Since the KC-1 sample was stored in a shielded facility at $\sim 32^{\circ} \mathrm{C}$ for $9 \frac{1}{2}$ months longer than $\mathrm{KC}-2 / 3$, a significant fraction of the uranium metal originally present in $\mathrm{KC}-1$ likely reacted before the Series II testing began. During this storage period, gas bubbles were observed several times in the $\mathrm{KC}-1$ sludge container. Using the rate equation for uranium metal with oxygen-free water given in the Spent Nuclear Fuel Project Technical Databook, Volume 1 (Reilly 1998), an initial metal particle size of $\sim 800 \mu \mathrm{m}$ (Delegard et al. 2000), and temperature of $32^{\circ} \mathrm{C}$, approximately $75 \%$ of the starting uranium metal would be expected to corrode in a $91 / 2$-month period. Therefore, the $0.56 \mathrm{wt} \%$ metal content of $\mathrm{KC}-1$ is reasonably consistent with $\mathrm{KC}-2 / 3$ metal content when considering the impact of the storage period and the expected variation of a sample taken from a single canister barrel versus one created from a combination of sludge from 10 barrels $(\mathrm{KC}-2 / 3)$.

The KC-1 P500 sludge was about 3.7 wt\% uranium metal, and the KC-1 M500 sludge was about $0.14 \mathrm{wt} \%$ uranium metal, based on $\mathrm{Kr}$ and $\mathrm{Xe}$ release. The higher metal concentration in larger size fraction sludge particles was observed in Series I tests with consolidated canister and floor sludges that were split at $250 \mu \mathrm{m}$. Considering the results from both Series I and Series II with fractionated canister sludge, it appears that very little uranium metal exists in canister sludge composed of particles less than $500 \mu \mathrm{m}$.

The uranium concentration in the total (combined) KC-1 sludge fractions is $0.57 \%$, in good agreement with the $0.56 \mathrm{wt} \%$ concentration found in the KC-1 Mix test. The abrasion experienced by the $\mathrm{KC}-1$ M500 and P500 sludge material during sieving likely provided good exposure of fresh uranium metal, providing results similar to the $\mathrm{KC}-1$ Mix sample. In Series I testing, $\mathrm{KC}-2 / 3 \mathrm{P} 250$ was estimated to contain $\sim 7.4 \mathrm{wt} \%$ uranium metal. The differences in metal content between KC-2/3 P250 and KC-1 P500 can partially be attributed to corrosion that likely occurred during the storage of the $\mathrm{KC}-1$ sample.

Uranium metal concentrations for the single-pull floor and pit sludges FE-1, FE-3, FE-5, and FE-4/6 are low $(0.0013$ to $0.027 \mathrm{wt} \%)$ and not strongly dependent on the method used (determination based on $\mathrm{H}_{2}$, $\mathrm{O}_{2}$, and $\mathrm{N}_{2}$ reaction gases or fission product gas release). Hydrocarbon gas release from sources other than decomposition of uranium carbide evidently are occurring for these materials, based on the low relative methane concentration in the hydrocarbon fraction and high hydrocarbon amounts in the product gas. The uranium metal content estimated in these samples is consistent with the results from Series I testing with KE floor sludges. From Series I testing, KE Basin floor sludge was estimated to contain less than $0.15 \mathrm{wt} \%$ uranium metal.

Uranium metal concentrations in the organic ion exchange resin sludge, $\mathrm{KC}-6$, could not be determined by fission product gas release because of concentrations below the mass spectrometric detection limit. The uranium metal concentration determined from $\mathrm{H}_{2}, \mathrm{O}_{2}$, and $\mathrm{N}_{2}$ reaction gases for the KC- 6 sludge is $0.026 \mathrm{wt} \%$. The hydrocarbon concentration (primarily due to methane and known carbide concentrations in the uranium metal fuel) was found to be consistent with the uranium metal corrosion estimated from corrosion gases in the $\mathrm{KC}-6$ test. At $95^{\circ} \mathrm{C}$, the maximum gas production from $\mathrm{KC}-6$ was $5 \times 10^{-4} \mathrm{~mole} / \mathrm{kg}$-day $(\sim 11 \mathrm{ml} / \mathrm{kg}$-day $)$. 
From the $\mathrm{Kr}$ and $\mathrm{Xe}$ release, the uranium metal content of the archived canister sludge sample, 96-06, was determined to be $\sim 0.9 \mathrm{wt} \%$. However, the quantity of hydrocarbon gas (generated by decomposition of the uranium carbide) measured during the test was about eight times lower than expected, based on the released fission gas measurements (i.e., hydrocarbon gas data alone would indicate that sample contained $\sim 0.1 \%$ uranium metal). During the 4 years at which this sample was stored at $\sim 29^{\circ} \mathrm{C}$, an appreciable fraction of uranium metal initially present likely reacted.

\section{References}

Baker, R. B., T. L. Welsh, and B. J. Makenas. 2000. Sampling and Analysis Plan for Sludge from the 105-K Basins to Support Transport to and Storage in T Plant. HNF-6479, Rev. 0, Fluor Hanford, Inc., Richland, Washington.

Delegard, C. H., S. A. Bryan, A. J. Schmidt, P. R. Bredt, C. M. King, R. L. Sell, L. L. Burger, and K. L. Silvers. 2000. Gas Generation from K East Basin Sludges - Series I Testing. PNNL-13320, Pacific Northwest National Laboratory, Richland, Washington.

Makenas, B. J., T. L. Welsh, R. B. Baker, D. R. Hansen, and G. R. Golcar. 1996. Analysis of Sludge from Hanford K East Basin Floor and Weasel Pit. WHC-SP-1182, Westinghouse Hanford Company, Richland, Washington.

Makenas, B. J., T. L. Welsh, R. B. Baker, E. W. Hoppe, A. J. Schmidt, J. Abrefah, J. M. Tingey, P. R. Bredt, and G. R. Golcar. 1997. Analysis of Sludge from Hanford K East Basin Canisters. HNF-SP-1201, DE\&S Hanford, Inc., Richland, Washington.

Makenas, B. J. 2000. Data Quality Objectives for Analysis of Hanford K Basin Sludge to Support Transport to and Storage in T Plant. HNF-5345, Rev. 0, Fluor Hanford, Inc., Richland, Washington.

Reilly, M. A. 1998. Spent Nuclear Fuel Project Technical Databook, Volume 1. HNF-SD-SNF-TI-015, Rev. 6, DE\&S Hanford, Inc., Richland, Washington. 


\section{Contents}

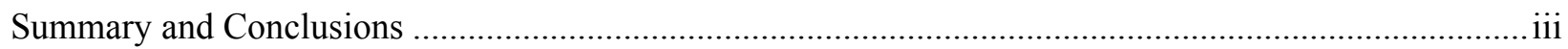

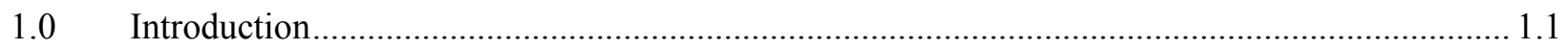

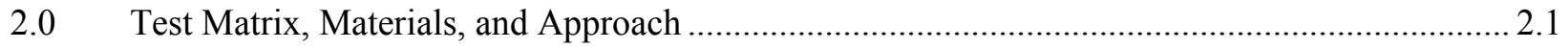

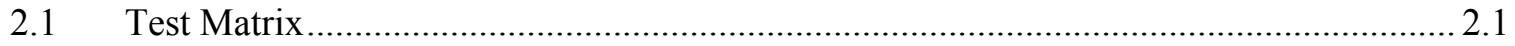

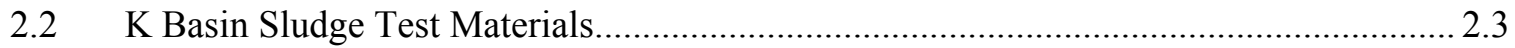

2.2.1 Consolidated Sludge Samples: KC-1 and KC-6 …........................................ 2.3

2.2.2 Single-Pull Core KE Floor and Pit Composite Samples: FE-1, FE-3, FE-5,

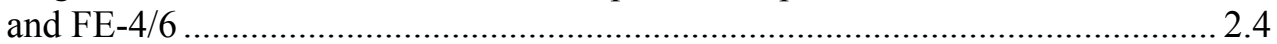

2.2.3 KE Canister Sludge from 1996 Sampling Campaign: 96-06 ............................... 2.6

2.2.4 Chemical and Radiochemical Composition of Sludge Samples ......................... 2.6

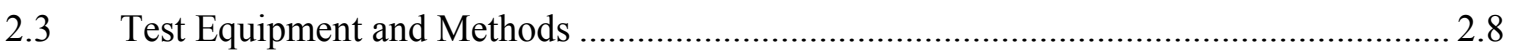

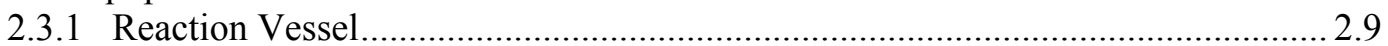

2.3.2 Volume Determinations of System Components ............................................ 2.9

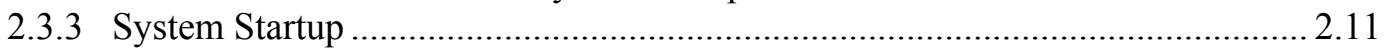

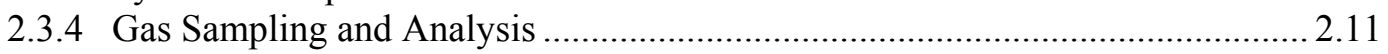

3.0 Gas Generation from KE Basin Sludge Samples ................................................................... 3.1

3.1 Gas Generation Results for Mixed and Unmixed KC-1 Canister Sludge at

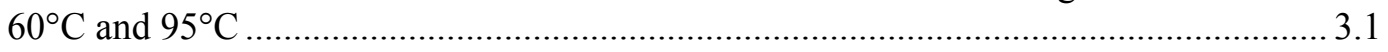

3.2 Gas Generation Results for KC-1 P500 and M500 Canister Sludge at

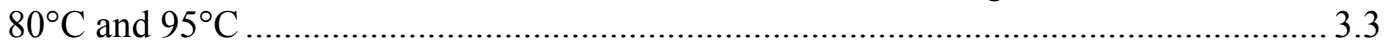

3.3 Gas Generation Results for Single-Pull Core Samples FE-1, FE-3, FE-5 and

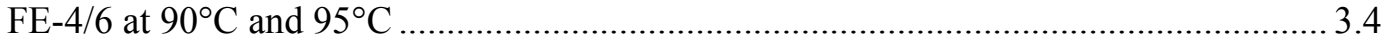

3.4 Gas Generation Results for KC-6, Ion Exchange Material Sludge, at $90^{\circ} \mathrm{C}$

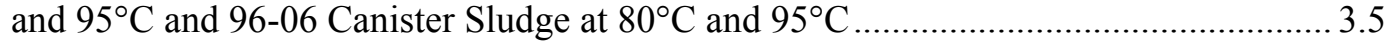

4.0 Discussion and Interpretation of Series II Results ........................................................... 4.1

4.1 Gas Generating and Gas Consuming Reactions ....................................................... 4.1

4.1.1 Uranium Corrosion and the Roles of Hydrogen, Oxygen, and Nitrogen............... 4.1

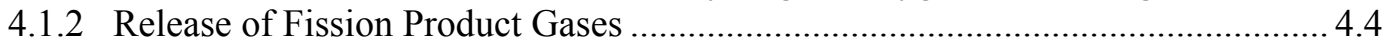

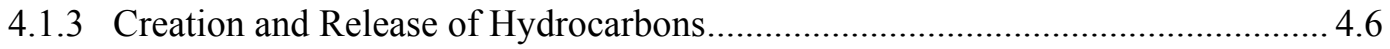

4.1.4 Carbon Dioxide Generation ........................................................................ 4.7

4.2 Gas Analysis for the Mixed and Unmixed $\mathrm{KC}-1$ Canister Sludge at $60^{\circ} \mathrm{C}$ and $95^{\circ} \mathrm{C} \ldots . . .4 .7$ 


\section{Contents (continued)}

4.3 Gas Analysis for KC-1 P500 and M500 Canister Sludge at $80^{\circ} \mathrm{C}$ and $95^{\circ} \mathrm{C}$

4.4 Gas Analysis for FE-1, FE-3, FE-5, and FE-4/6 Single-Pull Sludges

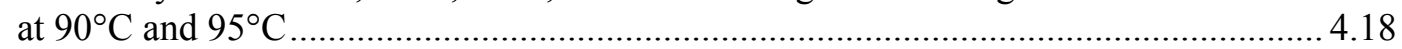

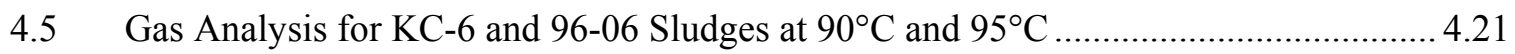

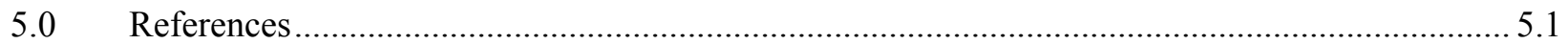

Appendix A Gas Analysis and Gas Generation Rate Data ............................................................. A.1

Appendix B Estimation of KC-1 Uranium Metal Content on October 7, 1999 (Start of Gas

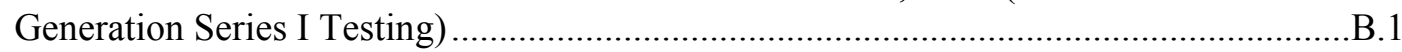




\section{Figures}

2.1 Layout of Gas Pressure Measurement and Gas Sampling Manifold Used in Gas

Generation Tests .

2.2 Reaction Vessel (60-ml) Used in Series II Gas Generation Tests

3.1 Total Gas Generation from KC-1 Mixed (Mix) and Unmixed (Un) Settled Sludge Material at $60^{\circ} \mathrm{C}$ and Completed at $95^{\circ} \mathrm{C}$

3.2 Total Gas Generation from KC-1 P500 and M500 (Settled Sludge) at $80^{\circ} \mathrm{C}$ and Completed at $95^{\circ} \mathrm{C}$

3.3 Total Gas Generation from FE-1, FE-3, FE-5, and FE-4/6 (Settled Sludge) at $90^{\circ} \mathrm{C}$ and $95^{\circ} \mathrm{C}$

3.4 Total Gas Generation from KC-6 (Settled Sludge) at $90^{\circ} \mathrm{C}$ and $95^{\circ} \mathrm{C}$ and

96-06 (Settled Sludge) at $80^{\circ} \mathrm{C}$ and $95^{\circ} \mathrm{C}$

4.1 Uranium Corrosion in KC-2/3 P250 Series I Small-Scale Tests, as Monitored by

Total Xe Release, Xe Released by Uranium Reaction with Water, and Corrosion

Gases $\left(\mathrm{H}_{2}\right.$ from $\mathrm{H}_{2} \mathrm{O} ; \mathrm{O}_{2} ;$ and $\left.\mathrm{N}_{2}\right)$......

4.2 Comparison of Uranium Metal Concentrations Determined by Corrosion Reactions and by Release of Kr and Xe Fission Product Gases at Nominal $2900 \mathrm{MWD} / \mathrm{TeU}$

Irradiation for Series I and Series II Tests 4.6

4.3 Inverse Cubic Function $\mathrm{CO}_{2}$ Generation Kinetics Plot in the $\mathrm{KC}-1$ Mix and $\mathrm{KC}-1 \mathrm{Un}$ Tests at $95^{\circ} \mathrm{C}$

\section{Tables}

2.1 K Basin Test Material Masses and Gas Sampling Schedule................................................... 2.2

2.2 Sampling Information for Consolidated Samples in Series II Gas Generation Testing............... 2.4

2.3 KE Basin Floor Single-Pull Core Composite Samples [Shipped to 325A HLRF (May 2000) for Testing].

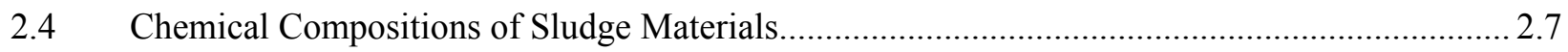

2.5 Crystalline Phases Identified by X-ray Diffractometry in Selected KE Basin Sludges ............... 2.8

2.6 Sludge $\mathrm{pH}$ Values Measured Before and After Testing ...................................................... 2.8 


\section{Tables (continued)}

2.7 Masses of Settled Sludge and Vessel Volumes Used in Gas Generation Tests......

4.1 Net and Cumulative Quantities of Gas Evolved for KC-1 Un and KC-1 Mix at $60^{\circ} \mathrm{C}$ and $95^{\circ} \mathrm{C}$

4.2 Reacted Metallic Uranium Calculated from Gas Generation and Consumption Reactions in KC-1 Un and KC-1 Mix Tests....

4.3 Isotope Ratios for $\mathrm{KC}-1$ Un and $\mathrm{KC}-1$ Mix Tests

4.4 Net and Cumulative Quantities of Gas Evolved for KC-1 P500 and M500 at $80^{\circ} \mathrm{C}$ and $95^{\circ} \mathrm{C}$

4.5 Reacted Metallic Uranium Calculated from Gas Generation and Consumption Reactions in KC-1 P500 and M500 Tests.

4.6 Isotope Ratios for KC-1 P500 and M500 Tests

4.7 Net and Cumulative Quantities of Gas Evolved for FE-1, FE-3, FE-5, and FE-4/6 at $90^{\circ} \mathrm{C}$ and $95^{\circ} \mathrm{C}$

4.8 Reacted Metallic Uranium Calculated from Gas Generation and Consumption Reactions in FE-1, FE-3, FE-5, and FE-4/6 Tests

4.9 Isotope Ratios for FE-1, FE-3, FE-5, and FE-4/6 Tests

4.10 Net and Cumulative Quantities of Gas Evolved for KC-6 at $90^{\circ} \mathrm{C}$ and $95^{\circ} \mathrm{C}$ and $96-06$ at $80^{\circ} \mathrm{C}$ and $95^{\circ} \mathrm{C}$

4.11 Reacted Metallic Uranium Calculated from Gas Generation and Consumption Reactions in $\mathrm{KC}-6$ and 96-06 Tests.

4.12 Isotope Ratios for 96-06 Test. 


\subsection{Introduction}

Two water-filled concrete pools [K East (KE) and K West (KW) Basins] in the 100K Area of the Hanford Site contain over 2100 metric tons of N Reactor fuel elements stored in aluminum or stainless steel canisters. During the time the fuel has been stored, approximately $52 \mathrm{~m}^{3}$ of heterogeneous solid material (sludge) have accumulated in the canisters, as well as on the floor and in the associated pits. This sludge consists of various proportions of fuel, structural corrosion products, windblown material, and miscellaneous constituents such as ion exchange material (IXM) (both organic and inorganic) and paint chips (Makenas et al. 1996-99). Pearce and Klimper (2000) describe the inventory and compositions of all K Basin sludge materials in detail. The baseline sludge management plan calls for the sludge to be packaged, shipped, and stored at T Plant in the Hanford 200 Area until final processing at a future date.

Because the sludge produces gas from chemical and, to a more limited extent, radiolytic reactions, gas generation must be considered when developing and evaluating designs for sludge retrieval, transportation, and storage systems. The work discussed in this report is being conducted by Pacific Northwest National Laboratory (PNNL) on actual sludge samples to better understand the reactivity and assess the reaction rates. The work is being performed for the Spent Nuclear Fuel Sludge Handling Project managed by Fluor Hanford, Inc., and is being performed in accordance with the data quality objectives (Makenas 2000) and the sampling and analysis plan (Baker et al. 2000).

This report (Series II) is the second in a series of three, and examines the gas generation behavior of KE canister sludge (mixed and unmixed and fractionated based on particle size) and KE floor and pit sludge from locations not sampled during the 1995 campaign (Makenas et al. 1996). Series I testing (Delegard et al. 2000) focused on gas generation from KE floor and canister sludge collected using a consolidated sampling technique. Series III testing is focused on gas generation from irradiated uranium fuel fragments with and without sludge addition.

The results of Series II testing and analyses conducted from July 2000 through September 2000 are provided here. The overall goal for this testing was to collect gas generation rate and composition data under known conditions to better understand the quantity and reactivity of the metallic uranium present in the K Basin sludge. Specific objectives for Series II testing included:

1. Evaluate the reactivity and determine the quantity of uranium metal present in each sludge type.

2. Provide gas generation data that can be used as design input into sludge transportation and storage systems.

3. Determine whether the reactivity of KE canister sludge is affected by aggressive agitation and sieving.

4. Obtain data on the expected uranium metal fraction and particle size in KE canister sludge to provide a basis for selecting values to be used in analyses.

5. Determine the reactivity of the single-pull (core) KE floor and pit sludge samples.

6. Evaluate the gas generation behavior of KE floor sludge consisting primarily of organic ion exchange material.

7. Evaluate the residual reactivity of archived KE canister sludge collected in 1996 that initially displayed a significant gas generation rate.

8. Compare the gas generation behavior of sludge collected by two different sampling techniques from the same general location. 
Ten gas generation tests were conducted with $\mathrm{K}$ Basin sludge: four with $\mathrm{KE}$ canister sludge sample $\mathrm{KC}-1$; four with $\mathrm{KE}$ floor and pit samples FE-1, FE-3, FE-5, and FE-4/6; one with KE floor sample KC-6, which primarily consists of organic ion exchange resin beads; and one with KE canister sample, 96-06, a highly reactive sludge collected in 1996 (see Makenas et al. 1997 for sample composition/details).

Section 2.0 describes the experimental methods and materials for the gas measurements, and Section 3.0 presents the data derived from the testing. During the tests, hydrogen; fission gas products, krypton and xenon; methane and higher hydrocarbons; and carbon dioxide were observed. At the same time, oxygen and nitrogen in the test vessels were consumed (depleted). Section 4.0 details the chemistry of the gas generating (and consuming) reactions and interprets and discusses the test results. Appendix A summarizes the gas composition and generation rates from the gas sampling. Two other tests were also included in this series (a large-scale canister sludge test and a fuel fragment test), but these tests are ongoing and will be discussed in the Series III testing report. Appendix B provides an estimate of the uranium metal content of sample KC-1 on October 7, 1999 (i.e., start date of Gas Generation Series I testing).

A technical data package containing the laboratory bench sheets and raw data (i.e., test instructions, laboratory record book pages, calibrations, temperature and pressure data, gas analysis data, etc.) is available from Fluor Hanford, Inc. (R. B. Baker). 


\subsection{Test Matrix, Materials, and Approach}

This section describes the overall test approach and methods used for the Gas Generation Series II tests. A general description of the testing and the test matrix is provided in Section 2.1. This section also gives the rationale for each test. Section 2.2 provides details on KE sludge samples used in the testing. A summary of the sample collection and handling is given, as well as information on the chemical and radiochemical composition of the samples. The equipment and measurement techniques used for the testing are described in Section 2.3. The test system was the same system (with some upgrades) used in Series I, and details of its verification, reliability, and performance are provided in Appendix A of the Series I report (Delegard et al. 2000).

\subsection{Test Matrix}

For the gas generation testing, 14- to 27-gram settled sludge samples were placed into 60 -ml reaction vessels. The reaction vessels were sealed, connected to the manifold system, and purged with neon gas to remove air. Next, the vessels were heated to the target conditions, and temperatures and gas pressures were monitored continuously. Gas samples were collected twice from each vessel during the testing period and analyzed via mass spectrometry. The testing was initiated on July 24, 2000, and continued for approximately 950 hours to September 4, 2000. The tests were conducted at elevated temperatures (ranging from $60^{\circ} \mathrm{C}$ to $90^{\circ} \mathrm{C}$ ) to accelerate the reactions and provide conclusive gas generation data within a reasonable testing period. After about 300 hours, the temperatures in all test vessels were increased to $95^{\circ} \mathrm{C}$ for additional time ( $\sim 650$ hours) to force completion of the reactions.

Table 2.1 contains the general matrix for the gas generation testing and includes the gas sampling schedule. These tests were conducted at PNNL's High-Level Radiochemistry Facility in the 325 Building (325A HLRF), 300 Area, in accordance with the sampling and analysis plan (Baker et al. 2000).

The first four gas generation tests shown in Table 2.1 were conducted using the KE canister sludge sample, KC-1. This sample was collected in April 1999 from a single storage canister barrel containing highly damaged fuel. A single-pull technique was used for sample collection (Pitner 1999). This sample contained $37 \mathrm{wt} \%$ (settled sludge basis) total uranium.

For the first two tests in Series II, an agitated (highly mixed) aliquot and an unmixed aliquot of KC-1 were used to investigate whether abrasive actions expected during $\mathrm{K}$ Basin retrieval operations have the potential to "activate" uranium metal in the sludge. The tests were also expected to provide insight into whether sieving operations, performed on some sludge samples, could affect the sludge reactivity. These two tests were started at $60^{\circ} \mathrm{C}$ (compared to initial temperatures of $80^{\circ} \mathrm{C}$ and $90^{\circ} \mathrm{C}$ for all other tests). This lower temperature reduced the overall reaction rate, magnifying the potential effect of agitation on induction time. [Note: In contrast with the test temperatures, the temperature for $\mathrm{K}$ Basin pool operations ranges from about $10^{\circ} \mathrm{C}$ to $25^{\circ} \mathrm{C}$.]

For the second two tests, a portion of $\mathrm{KC}-1$ was sieved to separate particles greater than, or "plus," $500 \mu \mathrm{m}$ (P500) from particles less than, or "minus," $500 \mu \mathrm{m}$ (M500). This separation was made to mimic the separation operations that are planned for the retrieval of certain K Basin sludge types and to gain a better understanding of how uranium metal is distributed in the sludge as a function of particle size. 
Table 2.1. K Basin Test Material Masses and Gas Sampling Schedule

\begin{tabular}{|c|c|c|c|c|c|c|c|}
\hline & \multirow{2}{*}{ Test Identification } & \multirow{2}{*}{$\begin{array}{c}\text { Settled Sludge } \\
\text { Mass, } g\end{array}$} & \multirow{2}{*}{$\begin{array}{c}\text { Test } \\
\text { Temp., }{ }^{\circ} \mathrm{C}\end{array}$} & \multirow{2}{*}{$\begin{array}{l}\text { Start } \\
\text { Date }\end{array}$} & \multirow{2}{*}{$\begin{array}{c}\text { Sample } \\
\text { Date }\end{array}$} & \multicolumn{2}{|c|}{ Time at Temperature, $\mathrm{hr}$} \\
\hline & & & & & & Run Interval $^{(\mathbf{b})}$ & Total $^{(\mathrm{b})}$ \\
\hline \multicolumn{8}{|c|}{ KE Canister Sludge (collected April 1999) } \\
\hline 1 & KC-1 Unmixed & 23.75 & 60 & $7 / 24 / 00$ & $8 / 7 / 00^{(a)}$ & 293 & 293 \\
\hline & & & 95 & $8 / 7 / 00$ & $8 / 14 / 00$ & 1. 167 at $95^{\circ} \mathrm{C}$ & 1. 459 \\
\hline & & & 95 & $8 / 15 / 00$ & $9 / 4 / 00$ & 2. 477 & 2. 936 \\
\hline 2 & KC-1 Mixed & 25.61 & 60 & $7 / 24 / 00$ & $8 / 7 / 00^{(a)}$ & 330 & 330 \\
\hline & (highly agitated) & & 95 & $8 / 7 / 00$ & $8 / 14 / 00$ & 1. 167 at $95^{\circ} \mathrm{C}$ & 1. 496 \\
\hline & & & 95 & $8 / 15 / 00$ & $9 / 4 / 00$ & 2. 477 & 2. 973 \\
\hline 3 & KC-1 P500 & 14.15 & 80 & $7 / 24 / 00$ & $8 / 7 / 00^{(a)}$ & 326 & 326 \\
\hline & (particles greater & & 95 & $8 / 7 / 00$ & $8 / 14 / 00$ & 1. 166 at $95^{\circ} \mathrm{C}$ & 1. 492 \\
\hline & than $500 \mu \mathrm{m})$ & & 95 & $8 / 15 / 00$ & $9 / 4 / 00$ & 2. 477 & 2. 969 \\
\hline 4 & KC-1 M500 & 22.30 & 80 & $7 / 24 / 00$ & $8 / 7 / 00^{(a)}$ & 321 & 321 \\
\hline & (particles less than & & 95 & $8 / 7 / 00$ & $8 / 14 / 00$ & 1. 166 at $95^{\circ} \mathrm{C}$ & 1. 488 \\
\hline & $500 \mu \mathrm{m})$ & & 95 & $8 / 15 / 00$ & $9 / 4 / 00$ & 2. 477 & 2. 965 \\
\hline \multicolumn{8}{|c|}{ KE Single-Pull Floor and Pit Sludge (Collected December 1998 - June 1999) } \\
\hline 5 & 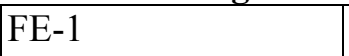 & 27.00 & 90 & $7 / 24 / 00$ & $8 / 7 / 00^{(a)}$ & 329 & 329 \\
\hline & Main Floor & & 95 & $8 / 7 / 00$ & $8 / 14 / 00$ & 1. 166 at $95^{\circ} \mathrm{C}$ & 1. 495 \\
\hline & & & 95 & $8 / 15 / 00$ & $9 / 4 / 00$ & 2. 477 & 2. 972 \\
\hline 6 & FE-3 & 21.22 & 90 & $7 / 24 / 00$ & $8 / 7 / 00^{(a)}$ & 327 & 327 \\
\hline & North Loadout Pit & & 95 & $8 / 7 / 00$ & $8 / 14 / 00$ & 1. 166 at $95^{\circ} \mathrm{C}$ & 1. 493 \\
\hline & & & 95 & $8 / 15 / 00$ & $9 / 4 / 00$ & 2. 477 & 2. 970 \\
\hline 7 & FE-5 & 19.93 & 90 & $7 / 24 / 00$ & $8 / 7 / 00^{(a)}$ & 327 & 327 \\
\hline & Weasel Pit & & 95 & $8 / 7 / 00$ & $8 / 14 / 00$ & 1. 166 at $95^{\circ} \mathrm{C}$ & 1. 493 \\
\hline & & & 95 & $8 / 15 / 00$ & $9 / 4 / 00$ & 2. 476 & 2. 970 \\
\hline 8 & FE-4/6 & 15.87 & 90 & $7 / 24 / 00$ & $8 / 7 / 00^{(a)}$ & 326 & 326 \\
\hline & Dummy Elevator and & & 95 & $8 / 7 / 00$ & $8 / 14 / 00$ & 1. 160 at $95^{\circ} \mathrm{C}$ & 1. 486 \\
\hline & Tech View Pit & & 95 & $8 / 15 / 00$ & $9 / 4 / 00$ & 2. 477 & 2. 963 \\
\hline \multicolumn{8}{|c|}{ Other Tests } \\
\hline 9 & KC-6 & 19.10 & 90 & $7 / 24 / 00$ & $8 / 7 / 00^{(\mathrm{a})}$ & 327 & 327 \\
\hline & Organic Ion & & 95 & $8 / 7 / 00$ & $8 / 14 / 00$ & 1. 165 at $95^{\circ} \mathrm{C}$ & 1. 492 \\
\hline & $\begin{array}{l}\text { Exchange Resin } \\
\text { (Collected April } \\
1999)\end{array}$ & & 95 & $8 / 15 / 00$ & $9 / 4 / 00$ & 2. 477 & 2. 968 \\
\hline 10 & \begin{tabular}{|l|}
$96-06$ \\
\end{tabular} & 19.51 & 80 & $7 / 24 / 00$ & $8 / 7 / 00^{(a)}$ & 324 & 324 \\
\hline & KE Canister Sludge & & 95 & $8 / 7 / 00$ & $8 / 14 / 00$ & 1. 147 at $95^{\circ} \mathrm{C}$ & 1. 471 \\
\hline & $\begin{array}{l}\text { (Collected March } \\
\text { 1996) }\end{array}$ & & 95 & $8 / 15 / 00$ & $9 / 4 / 00$ & 2. 477 & 2. 947 \\
\hline
\end{tabular}

(a) Dates of temperature transitions without sampling.

(b) Numbers (1 and 2) indicate when first and second gas sample was collected. 
Tests 5 through 8 shown in Table 2.1 used samples collected from the KE floor and pits between December 1998 and June 1999: main basin floor (FE-1), North Loadout Pit (FE-3), Weasel Pit (FE-5), and Tech View Pit and Dummy Elevator Pit (FE-4/6). These tests were conducted to show how gas generation behavior varies as a function of sludge source location, and to provide further confirmation of the low reactivity of the KE floor and pit sludge. The North Loadout Pit, the Tech View Pit, and the Dummy Elevator Pit had not been sampled during previous sampling and characterization campaigns. Also, sludge from the South Loadout Pit had been added to the Weasel Pit after it was sampled and characterized in 1995 (Makenas et al. 1996). Therefore, these tests provided the first opportunity to characterize the gas generation behavior of sludge from these pits.

Test 9 was conducted with a sample (KC-6) collected from the KE floor. This sample primarily consisted of organic ion exchange resin beads. This type of sludge is unique, and the test was conducted to gain an understanding of its long-term stability under T Plant storage conditions.

Test 10 was conducted to determine if the highly reactive sludge, 96-06, collected during the $1996 \mathrm{KE}$ canister sampling campaign, still exhibited reactivity and gas generation potential. In the $1996 \mathrm{KE}$ canister sludge characterization campaign, sample 96-06 exhibited a high gas generation rate (up to $150 \mathrm{ml} / \mathrm{kg}$ settled sludge-day) at ambient hot cell temperatures $\left(\sim 32^{\circ} \mathrm{C}\right)$ (Makenas et al. 1997; Delegard et al. 2000).

\subsection{K Basin Sludge Test Materials}

The sample collection methods and sample histories for the materials used in the gas generation testing are described below.

\subsubsection{Consolidated Sludge Samples: KC-1 and KC-6}

Consolidated samples (Baker et al. 2000), including KC-1 and KC-6 (along with four others), were collected from the KE Basin in March and April 1999 by a technique whereby a vacuum is applied and sludge is drawn into 10.3-L sample containers (stainless steel vessels). Sludge was trapped in the container while the excess water returned to the basin through a 5- $\mu \mathrm{m}$ stainless steel filter. Compared with the single-pull techniques, this consolidated sampling technique collected much larger volumes of sludge from several different sampling locations in the same sample container. However, for sample $\mathrm{KC}-1$, the sampling system was operated in a single-pull mode (i.e., a filter was not used, and the sampling was terminated after the 10.3-L sample container was filled); hence, no material or water was allowed to escape. This technique was used to confirm that the loss of fine sludge material through the filter used for the other samples was insignificant.

Facility records show that the $\mathrm{KE}$ Basin water $\mathrm{pH}$ ranged from 5.3 to 5.7 and averaged 5.44 during the sampling period. The temperature ranged from $13^{\circ} \mathrm{C}$ to $17^{\circ} \mathrm{C}$. Pitner (1999) provides a detailed description of the sampling equipment and the consolidated sludge sampling campaign.

Sample KC-1 was collected from the east barrel of the canister in Cubicle 4569 in the KE Basin, which contained highly degraded fuel. Sample KC-6 was collected from Cubicle 6758, which contained no fuel canisters. Earlier surveys identified this cubicle as containing a high concentration of organic ion exchange resin beads. Visual observations of this sample confirmed that the sample was almost 
exclusively composed of organic ion exchange resin beads. In a previous investigation, the resin beads were identified as Purolite NRW 37 ion exchange resin (Schmidt et al. 1998).

In May 1999, the consolidated samples were transferred from the Postirradiation Testing Laboratory (327 Building) to the 325A HLRF. The sample containers were inspected upon receipt for indications of excessive gas generation during shipment. No explicit evidence was found to indicate gas generation occurred in the sludge during the transport. Table 2.2 summarizes the sampling information and history for $\mathrm{KC}-1$ and $\mathrm{KC}-6$.

The samples that made up the consolidated canister sludge composite (KC-2/3) used in some Series I tests were collected from the KE Basin and transferred to the 325A HLRF at the same time as KC-1 and KC-6. However, $\mathrm{KC}-2 / 3$ was stored in the hot cell $\left(\sim 32^{\circ} \mathrm{C}\right)$ for only 5 months before the start of Series I testing. In comparison, $\mathrm{KC}-1$ and $\mathrm{KC}-6$ were stored for about 14 months at $\sim 32^{\circ} \mathrm{C}$ before the start of Series II in July 2000. Because the hot cell was $15^{\circ} \mathrm{C}$ to $20^{\circ} \mathrm{C}$ warmer than the $\mathrm{KE}$ Basin pool, the uranium metal corrosion rate in the samples is calculated to be 2.5 to 3.8 times higher than that experienced by equivalent sludge remaining in the pool.

Table 2.2. Sampling Information for Consolidated Samples in Series II Gas Generation Testing

\begin{tabular}{|l|l|l|l|}
\hline Container & Material Type & $\begin{array}{c}\text { Date } \\
\text { Collected from } \\
\text { KE Basin }\end{array}$ & $\begin{array}{c}\text { Date Received at } \\
\text { 325A HLRF } \\
\text { (Storage at } \sim 32^{\circ} \mathbf{C} \text { ) }\end{array}$ \\
\hline KC-1 & $\begin{array}{l}\text { Canister Sludge from } \\
\text { Highly Damaged Fuel }\end{array}$ & April 1999 & May 7, 1999 \\
\hline KC-6 & $\begin{array}{l}\text { Floor Sludge Containing } \\
\text { High Concentrations of } \\
\mathrm{IXM}^{(\mathrm{a})} \text { Beads }\end{array}$ & March 1999 & May 7, 1999 \\
\hline
\end{tabular}

(a) Ion exchange material.

A subsample of KC-1 was wet-sieved through a Tyler-32 mesh screen (500- $\mu \mathrm{m}$ openings) to separate the P500 and M500 fractions. A portion of sludge was placed on top of the Tyler-32 sieve. The loaded sieve was then raised and lowered repeatedly into a pan filled with supernatant KE Basin water taken from the respective sample container. As the sieve was raised, particles smaller than $500 \mu \mathrm{m}$ drained into the pan. The solids on the Tyler-32 sieve were immediately transferred to a large vessel filled with clean supernatant to keep the sludge wet at all times. On a wet sludge basis, $11.7 \mathrm{wt} \%$ of $\mathrm{KC}-1$ material was greater than $500 \mu \mathrm{m}$. In an earlier characterization campaign that used multiple sieves and a more conventional sieving protocol, it was estimated that only $5.5 \%$ of $\mathrm{KC}-1$ (wet sample basis) was greater than $500 \mu \mathrm{m}$ (Bredt et al. 1999). The different sieving techniques likely affected the water content of the material retained on the sieve(s).

\subsubsection{Single-Pull Core KE Floor and Pit Composite Samples: FE-1, FE-3, FE-5, and FE-4/6}

In the single-pull core sampling campaign, KE Basin floor and pit sludge samples were collected between December 1998 and June 1999. For this sample collection, single-pull sampling equipment was used in which isolated cores of sludge were suctioned into 4-L bottles. The samples were immediately shipped to the Hanford 222-S Laboratory in the 200 West Area for characterization (Baker et al. 2000) and interim storage. Following receipt at 222-S, six composites were prepared (FE-1, FE-3, FE-4, FE-5, FE-6, and 
FE-7) by combining the solids in the sample bottles. During storage at 222-S (11 to 17 months, depending on the sample), the temperature of the sludge samples was approximately $27^{\circ} \mathrm{C}$. Details on the single-pull core sampling campaign can be found in Pitner (1999).

In May 2000, portions of five of the composites (FE-1, FE-3, FE-4, FE-5, and FE-6) were transferred to 325A HLRF. Table 2.3 lists the five composites shipped to 325A HLRF and identifies the original sample bottles used for each composite. With the exception of sample FE-4 (Dummy Elevator Pit sludge), all samples received at 325A HLRF contained wet solids with standing liquid. Sample FE-4 was received as moist solids, but with no standing water. Supernatant from other KE floor sludge samples was added to FE-4 to generate a wet slurry with standing liquid. In 325A HLRF, the samples were at a temperature of approximately $32^{\circ} \mathrm{C}$ for 2 months before the Series II tests were initiated.

Because of higher priority analyses performed at the 222-S Laboratory, the amount of sludge material available from FE-4 and FE-6 was insufficient for the required characterization analyses and the gas generation tests. Consequently, $10.2 \mathrm{~g}$ of FE-4 and $5.9 \mathrm{~g}$ of FE- 6 were combined to form a composite, designated as FE-4/6.

Table 2.3. KE Basin Floor Single-Pull Core Composite Samples [Shipped to 325A HLRF (May 2000) for Testing]

\begin{tabular}{|c|c|c|c|}
\hline Composite & $\begin{array}{c}\text { Original Sample } \\
\text { Bottles }\end{array}$ & KE Area Represented & $\begin{array}{c}\text { Date } \\
\text { Collected } \\
\text { from KE } \\
\text { Basin }^{(a)}\end{array}$ \\
\hline \multirow{2}{*}{$\begin{array}{c}\text { FE-1 } \\
\text { Main Floor }\end{array}$} & $\begin{array}{l}\text { KE-1-A, KE-1-B } \\
\text { KE-1-D, KE-1-E }\end{array}$ & $\begin{array}{l}\text { East Bay, Cubicle } 0168 \\
\text { South Side, Empty } \\
\text { Cubicle }\end{array}$ & Jan. 1999 \\
\hline & KE-2-A, KE-2-B & $\begin{array}{l}\text { East Bay, Cubicle 1065, } \\
\text { N. Side }\end{array}$ & Dec. 1998 \\
\hline \multirow{2}{*}{$\begin{array}{c}\text { FE-3 } \\
\text { North Loadout } \\
\text { Pit }\end{array}$} & $\begin{array}{l}\text { KE-5-A, KE-5-B, } \\
\text { KE-5-D, KE-5-E }\end{array}$ & $\begin{array}{l}\text { North Loadout Pit } \\
\text { (NLOP) Center }\end{array}$ & Jun. 1999 \\
\hline & KE-6-A, KE-6-B & $\begin{array}{l}\text { NLOP, Mid Transfer } \\
\text { Channel }\end{array}$ & Jun. 1999 \\
\hline \multirow{2}{*}{$\begin{array}{l}\text { FE-4 } \\
\text { Dummy } \\
\text { Elevator } \\
\text { Pit }\end{array}$} & KE-7-A, KE-7-B & $\begin{array}{l}\text { Dummy Elevator Pit, } \\
\text { East }\end{array}$ & Jan. 1999 \\
\hline & $\begin{array}{l}\text { KE-8-A, KE-8-B, } \\
\text { KE-8-D }\end{array}$ & $\begin{array}{l}\text { Dummy Elevator Pit, } \\
\text { West }\end{array}$ & Jan. 1999 \\
\hline \multirow{2}{*}{$\begin{array}{c}\text { FE-5 } \\
\text { Weasel Pit }\end{array}$} & $\begin{array}{l}\text { KE-9-A, KE-9-B, } \\
\text { KE-9-D, KE-9-E }\end{array}$ & $\begin{array}{l}\text { Weasel Pit, Near South } \\
\text { Wall, } 8 \text { feet from East } \\
\text { End }\end{array}$ & Apr. 1999 \\
\hline & $\begin{array}{l}\text { KE-10-A, KE-10-B, } \\
\text { KE-10-D, KE-10-E }\end{array}$ & $\begin{array}{l}\text { Weasel Pit, Near Center, } \\
11 \text { feet from West End }\end{array}$ & Jan. 1999 \\
\hline $\begin{array}{c}\text { FE-6 } \\
\text { Tech View Pit }\end{array}$ & KE-11-A, KE-11-B & $\begin{array}{l}\text { Just East of Channel to } \\
\text { View Pit }\end{array}$ & Jan. 1999 \\
\hline
\end{tabular}

(a) Within several days of sample collection, the samples were shipped to the 222-S Laboratory, where they were stored at $\sim 27^{\circ} \mathrm{C}$. Once sent to the $325 \mathrm{~A}$ HLRF, the samples were stored at $\sim 32^{\circ} \mathrm{C}$. 


\subsubsection{KE Canister Sludge from 1996 Sampling Campaign: 96-06}

KE canister sludge sample 96-06 was collected in April 1996, from the west barrel of the fuel canister in Cubicle 5465, using a sampling technique very similar to that described above for the single-pull samples (Makenas et al. 1997). The fuel in this barrel was highly degraded. In July and August 1996, this sample displayed significant gas generation at the ambient hot cell temperature $\left(\sim 32^{\circ} \mathrm{C}\right.$ in the $325 \mathrm{~A}$ HLRF). Further details on the sample collection, characterization, and gas generation behavior are provided in Makenas et al. (1997). Delegard et al. (2000) [Gas Generation Testing Series I report] also includes an analysis of the gas generation behavior of sample 96-06.

When sample characterization was completed in 1996, 96-06 was stored at an average temperature of about $29^{\circ} \mathrm{C}$ for 4 years until it was retrieved for the gas generation testing. While the sample had been covered with a layer of water when it was put into storage, it was found to be dry when retrieved in July 2000. K Basin canister supernatant water was added to reconstitute the sample to a wet sludge. The reconstituted sludge was aggressively mixed, and a subsample was collected for the gas generation test.

\subsubsection{Chemical and Radiochemical Composition of Sludge Samples}

The chemical compositions of the samples on a dry and an as-settled sludge basis are shown in Table 2.4. Radiochemical compositions of the sludges are also listed in this table. Details on the analyses performed on KC-1 are given in Elmore et al. (2000). The individual fractions of KC-1 (i.e., KC-1 P500 and KC-1 M500) were not characterized. Steen (2000) describes the analyses performed on the single-pull sludge samples, including FE-1, FE-3, FE-4, FE-5, and FE-6. The chemical and radiochemical characterization information in Table 2.4 for sample 96-06 was taken from Makenas et al. (1997). No analyses were performed on KC-6; however, a similar sample, KES-H-08, containing a high concentration of organic ion exchange resin beads, had already been characterized (Makenas et al. 1996), and those data are included in Table 2.4.

The crystalline phases present in the FE-3, FE-4, FE-5, and FE-6 sludges were determined by X-ray diffractometry (XRD) according to procedure PNNL-RPG-268. Results of the XRD analyses are given in Table 2.5. Quartz, $\mathrm{SiO}_{2}$, was found in FE-3, FE-4, and FE-5, but was the only Hanford soil mineral identified in any of the single-pull FE samples. Two $\mathrm{FeO}(\mathrm{OH})$ phases (lepidocrocite and goethite) were found in both FE-5 and FE-6; lepidocrocite also was found in FE-4. The iron phases likely arise from corrosion of structural steel in the KE Basin. No aluminum corrosion products [e.g., $\mathrm{Al}(\mathrm{OH})_{3}$ as gibbsite, bayerite, or nordstrandite] were identified in any sample. The only uranium phase found was studtite $\left(\mathrm{UO}_{4} \cdot 4 \mathrm{H}_{2} \mathrm{O}\right.$, a uranyl peroxide hydrate phase) observed in FE-6. Zirconium oxide, $\mathrm{ZrO}_{2}$, may be present in FE-3, but its identification is tentative. Though found in other KE Basin sludges (Makenas et al. 1996), no calcite $\left(\mathrm{CaCO}_{3}\right)$ was found in any of the four test samples. Mordenite $\left[\left(\mathrm{Ca}, \mathrm{Na}_{2}, \mathrm{~K}_{2}\right) \mathrm{Al}_{2} \mathrm{Si}_{10} \mathrm{O}_{24} \cdot 7 \mathrm{H}_{2} \mathrm{O}\right]$, an ion exchange mineral used to remove radiocesium from the KE Basin waters, also was not found in any sample by XRD. In sample FE-3, the phase associated with the most intense lines in the XRD pattern was not identified.

The only phases identified by XRD for sludge sample 96-06 are the various uraninites $\mathrm{UO}_{2}, \mathrm{U}_{4} \mathrm{O}_{9}$, and $\mathrm{U}_{3} \mathrm{O}_{7}$ (Makenas et al. 1997). 
Table 2.4. Chemical Compositions of Sludge Materials

\begin{tabular}{|c|c|c|c|c|c|c|c|}
\hline \multicolumn{8}{|c|}{ Concentration, dry basis } \\
\hline Analyte, wt\% & KC-1 & FE-1 & FE-3 & FE-5 & FE-4/6 & KES-H-08 ${ }^{(\mathbf{a})}$ & 96-06 ${ }^{(b)}$ \\
\hline $\mathrm{Al}$ & 2.04 & 1.36 & 0.987 & 2.65 & 2.79 & 1.87 & 1.45 \\
\hline $\mathrm{Ca}$ & 0.12 & 0.138 & 0.820 & 1.20 & 0.17 & 1.22 & $<0.02$ \\
\hline $\mathrm{Fe}$ & 0.338 & 46.8 & 3.37 & 30.6 & 18.3 & 1.51 & 0.180 \\
\hline $\mathrm{Mg}$ & 0.020 & 0.038 & 0.076 & 0.146 & 0.23 & 0.225 & $<0.02$ \\
\hline $\mathrm{Na}$ & 0.237 & $<0.03$ & 0.025 & $<0.03$ & 0.01 & 3.26 & 0.0441 \\
\hline $\mathrm{Si}$ & 0.160 & 0.166 & 0.154 & 0.329 & 0.23 & NA & NA \\
\hline $\mathrm{U}$ & 69.0 & 1.15 & 1.51 & 6.37 & 2.51 & 0.249 & 74.9 \\
\hline U, phos. & 68.6 & 1.32 & 1.72 & 5.32 & 1.74 & 0.287 & 61.1 \\
\hline TIC & NA & NA & 0.26 & 0.18 & 0.10 & 0.22 & 0.0581 \\
\hline TOC & NA & NA & 0.43 & 0.22 & 0.26 & $0.88^{(\mathbf{c})}$ & 0.0654 \\
\hline \multicolumn{8}{|l|}{ Analyte, $\mu \mathrm{Ci} / \mathrm{g}$} \\
\hline${ }^{60} \mathrm{Co}$ & 0.209 & 0.501 & 0.339 & 0.875 & 0.97 & 0.185 & $<0.857$ \\
\hline${ }^{137} \mathrm{Cs}$ & 392 & 17.4 & 18.8 & 170 & 38.83 & 144 & 320 \\
\hline${ }^{154} \mathrm{Eu}$ & 8.62 & 0.245 & 0.425 & 0.985 & 0.26 & $<0.04$ & 10.7 \\
\hline${ }^{241} \mathrm{Am}$ & 122 & 2.63 & 4.92 & 10.2 & 3.11 & 0.397 & 99.5 \\
\hline${ }^{238} \mathrm{Pu}$ & 21.4 & 0.562 & 0.918 & 2.06 & 0.61 & 0.062 & 18.3 \\
\hline${ }^{239,240} \mathrm{Pu}$ & 142 & 2.88 & 5.96 & 13.1 & 3.89 & 0.40 & 104 \\
\hline \multicolumn{8}{|c|}{ Concentration, settled sludge basis } \\
\hline Analyte, wt\% & KC-1 & FE-1 & FE-3 & FE-5 & FE-4/6 & KES-H-08 ${ }^{(\mathbf{a})}$ & $96-06^{(\mathbf{b})}$ \\
\hline $\mathrm{Al}$ & 1.11 & 0.95 & 0.472 & 1.74 & 2.160 & 0.854 & 0.958 \\
\hline $\mathrm{Ca}$ & 0.065 & 0.0964 & 0.392 & 0.79 & 0.130 & 0.558 & $<0.017$ \\
\hline $\mathrm{Fe}$ & 0.184 & 32.6 & 1.61 & 20.1 & 14.2 & 0.692 & 0.119 \\
\hline $\mathrm{Mg}$ & 0.011 & 0.026 & 0.036 & 0.096 & 0.179 & 0.103 & $<0.017$ \\
\hline $\mathrm{Na}$ & 0.129 & $<0.02$ & 0.0121 & $<0.017$ & 0.010 & 1.49 & 0.029 \\
\hline $\mathrm{Si}$ & 0.087 & 0.116 & 0.0734 & 0.216 & 0.179 & NA & NA \\
\hline $\mathrm{U}$ & 37.5 & 0.801 & 0.724 & 4.18 & 1.95 & 0.114 & 49.4 \\
\hline U, phos. & 37.2 & 0.922 & 0.820 & 3.49 & 1.35 & 0.144 & 40.3 \\
\hline TIC & NA & NA & 0.124 & 0.115 & 0.078 & 0.102 & 0.0383 \\
\hline TOC & NA & NA & 0.204 & 0.147 & 0.205 & 0.403 & 0.0431 \\
\hline Solids & 54.3 & 69.7 & 47.8 & 65.6 & 77.5 & NA & 64.8 \\
\hline \multicolumn{8}{|l|}{ Analyte, $\mu \mathrm{Ci} / \mathrm{g}$} \\
\hline${ }^{60} \mathrm{Co}$ & 0.113 & 0.349 & 0.162 & 0.574 & 0.748 & 0.699 & $<0.57$ \\
\hline${ }^{137} \mathrm{Cs}$ & 213 & 12.2 & 8.96 & 112 & 30.1 & 54.5 & 211 \\
\hline${ }^{154} \mathrm{Eu}$ & 4.68 & 0.171 & 0.203 & 0.646 & 0.201 & $<0.016$ & 7.05 \\
\hline${ }^{241} \mathrm{Am}$ & 66.2 & 1.83 & 2.35 & 6.72 & 2.41 & 0.15 & 53.2 \\
\hline${ }^{238} \mathrm{Pu}$ & 11.6 & 0.392 & 0.439 & 1.35 & 0.476 & 0.0234 & 12.1 \\
\hline${ }^{239,240} \mathrm{Pu}$ & 77.1 & 2.01 & 2.85 & 8.58 & 3.01 & 0.152 & 68.2 \\
\hline
\end{tabular}

(a) Sample KC-6 was not characterized. The data reported are from Sample KES-H-08, a similar sample containing high concentration of organic resin beads. KES-H-08 was collected and analyzed in 1995

(Makenas et al. 1996)

(b) from Makenas et al. (1997) for sample 96-06 M.

(c) Method used for TOC analysis did not measure organic content of polystyrene-based organic ion exchange resin.

TOC, total organic carbon; TIC, total inorganic carbon. 
Table 2.5. Crystalline Phases Identified by X-ray Diffractometry in Selected KE Basin Sludges

\begin{tabular}{|l|l|c|c|c|c|}
\hline \multirow{2}{*}{$\begin{array}{c}\text { Crystalline Phase } \\
\text { Name and Formula }\end{array}$} & \multirow{2}{*}{ PDF \# $\#^{(\mathbf{a})}$} & \multicolumn{4}{c|}{ Prominence in Sludge $^{(\mathbf{b})}$} \\
\cline { 3 - 6 } & & FE-3 & FE-4 & FE-5 & FE-6 \\
\hline Quartz, $\mathrm{SiO}_{2}$ & $46-1045$ & $\mathrm{H}$ & $\mathrm{H}$ & $\mathrm{H}$ & $\mathrm{N}$ \\
\hline Lepidocrocite, $\mathrm{FeO}(\mathrm{OH})$ & $8-098$ & $\mathrm{~N}$ & $\mathrm{~L}$ & $\mathrm{M}$ & $\mathrm{M}$ \\
\hline Goethite, $\mathrm{FeO}(\mathrm{OH})$ & $29-713$ & $\mathrm{~N}$ & $\mathrm{~N}$ & $\mathrm{M}$ & $\mathrm{M}$ \\
\hline Studtite, $\mathrm{UO}_{4} \cdot 4 \mathrm{H}_{2} \mathrm{O}$ & $16-206$ & $\mathrm{~N}$ & $\mathrm{~N}$ & $\mathrm{~N}$ & $\mathrm{M}$ \\
\hline Zirconium oxide, $\mathrm{ZrO}_{2}$ & $49-1642$ & Maybe & $\mathrm{N}$ & $\mathrm{N}$ & $\mathrm{N}$ \\
\hline
\end{tabular}

(a) $\mathrm{PDF} \#=$ powder diffraction file number.

(b) $\mathrm{H}$ - high; $\mathrm{M}$ - medium; L - low; $\mathrm{N}$ - not observed.

The $\mathrm{pH}$ of the settled sludge was measured both before and after the gas generation experiments, using a wand-type $\mathrm{pH}$ meter (Piccolo). For each set of measurements, the meter accuracy was verified, and the $\mathrm{pH}$ values corrected based on measurements of calibrated buffer solutions. Measurement accuracy is estimated to be $\pm 0.2 \mathrm{pH}$ units. The measured values shown in Table 2.6 indicate that little change in $\mathrm{pH}$ occurred during these tests.

Table 2.6. Sludge $\mathrm{pH}$ Values Measured Before and After Testing

\begin{tabular}{|l|c|c|}
\hline \multicolumn{1}{|c|}{ Sludge Tested } & Pre-Test pH & Post-Test pH \\
\hline KC-1 Un & 5.1 & 5.1 \\
\hline KC-1 Mix & 5.1 & 5.3 \\
\hline KC-1 M500 & 5.1 & 5.4 \\
\hline KC-1 P500 & 5.1 & 5.3 \\
\hline FE-1 & 6.8 & 6.8 \\
\hline FE-3 & 8.3 & 7.7 \\
\hline FE-5 & 7.9 & 7.8 \\
\hline FE-4/6 & Not measured & 6.8 \\
\hline KC-6 & 7.4 & 7.8 \\
\hline 96-06 & 5.0 & 5.1 \\
\hline
\end{tabular}

\subsection{Test Equipment and Methods}

The reaction vessels (Section 2.3.1) and the gas manifold system (Figure 2.1) used for the gas generation tests are similar to those described in previous work with K Basin sludge (Delegard et al. 2000), in earlier studies with simulated Hanford tank waste (Bryan and Pederson 1995), and in work with actual Hanford tank waste (Bryan et al. 1996; King et al. 1997). Each vessel has a separate pressure transducer on the gas manifold line. The entire surface of the reaction system exposed to the sludge sample is stainless steel, except for a gold-plated copper gasket sealing the flange at the top of the reaction vessel. For the tests, temperatures and pressures were recorded every 10 seconds on a Campbell Scientific CR10 datalogger; the data were averaged every 20 minutes and saved in a computer file. Temperature and pressure data were also manually logged once each working day. 


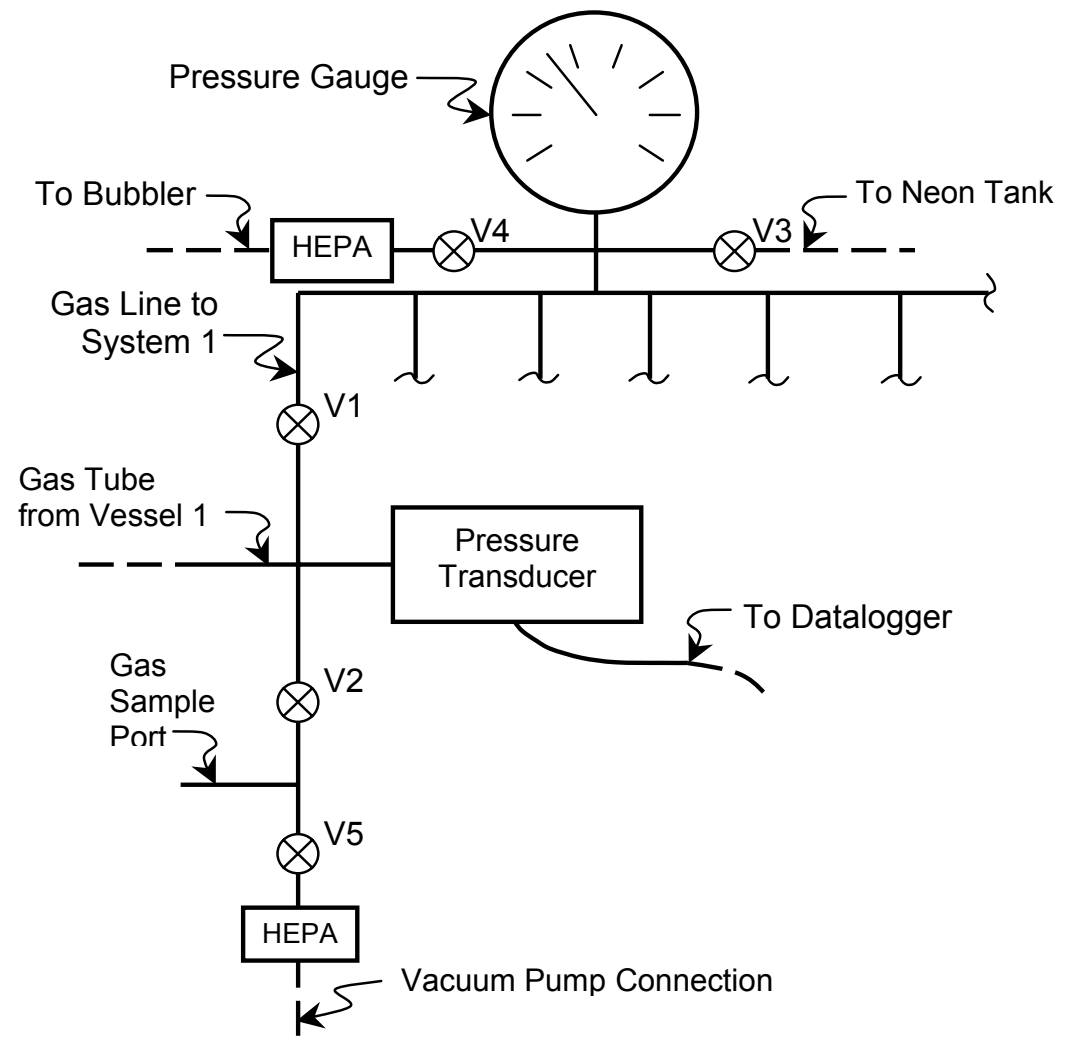

Figure 2.1. Layout of Gas Pressure Measurement and Gas Sampling Manifold Used in Gas Generation Tests (includes details for one of 12 systems)

\subsubsection{Reaction Vessel}

Figure 2.2 illustrates the $60-\mathrm{ml}$ reaction vessel and shows where the thermocouples are placed inside and outside. The reaction vessels are 304 stainless steel cylinders, each internally $\sim 1.75 \mathrm{~cm}$ diameter and $27 \mathrm{~cm}$ high (internal volume $\sim 62 \mathrm{~cm}^{3}$ ). For the gas generation testing, each vessel was wrapped in heating tape and insulated. Two thermocouples were attached to the external body, one for temperature control and one for over-temperature protection. Two thermocouples were inserted through the cap. The thermocouple centered in the lower half of the vessel monitored the temperature of the liquid phase; the one centered in the upper half monitored the gas phase temperature within the reaction vessel. The reaction vessels were placed in a hot cell and connected by a thin $(0.0058-\mathrm{cm}$ inside diameter $)$ stainless steel tube to the gas manifold outside the hot cell. A stainless steel filter $(60-\mu \mathrm{m}$ pore size, Nupro) protected the tubing and manifold from particulate contamination. A thermocouple was attached to this filter as well.

\subsubsection{Volume Determinations of System Components}

The total moles of gas in the system were calculated using the Ideal Gas Law from the pressure, temperature, and volume of the parts of the apparatus having different gas phase temperatures:

moles $_{\text {total }}=$ moles $_{\text {vessel }}+$ moles $_{\text {filter }}+$ moles $_{\text {manifold and tubing. }}$ The manifold and filter volumes were determined from pressure/volume relationships using a calibrated gas manifold system. The manifold volume (the 


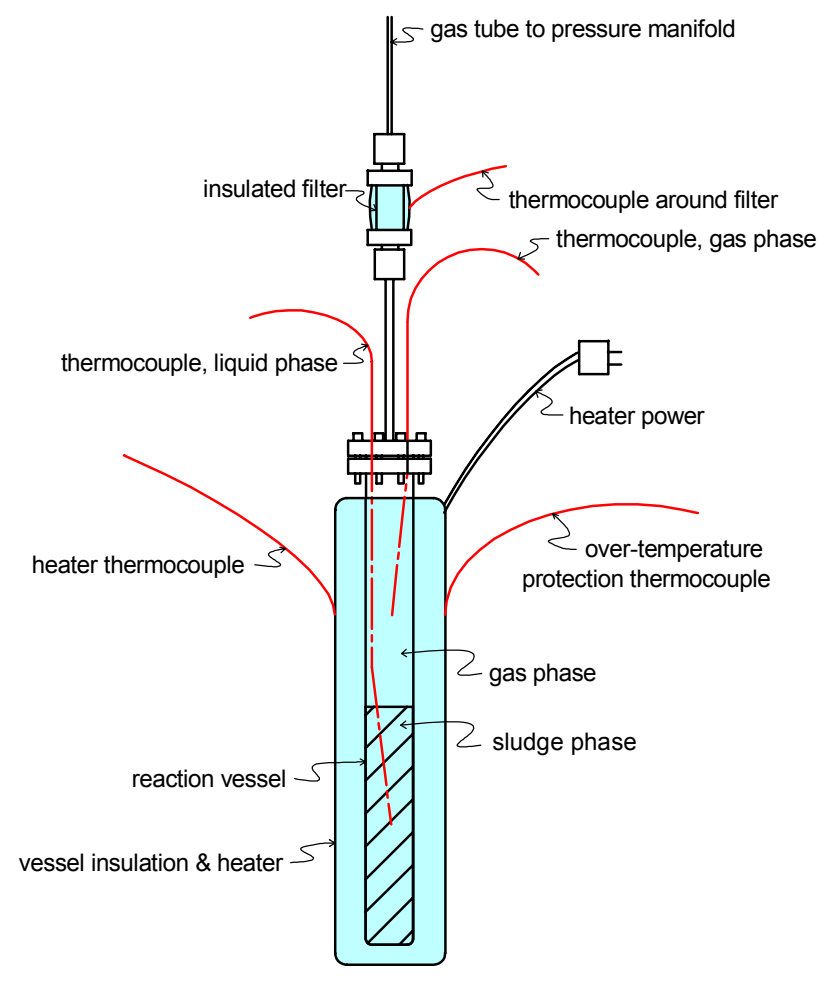

Figure 2.2. Reaction Vessel (60-ml) Used in Series II Gas Generation Tests

pressure sensor, valves, and miscellaneous fittings) was $3.99 \mathrm{ml}$; the filter volume was $1.34 \mathrm{ml}$; and the tubing volume was $1.715 \mathrm{ml}$ (by calculation). The cap stem (the tube from vessel to filter) had a volume of $0.20 \mathrm{ml}$; half of that was added to the filter volume, giving $1.44 \mathrm{ml}$, and half was added to the vessel volumes. The volume of each vessel was determined gravimetrically by filling it with water. These volumes are recorded in Table 2.7, along with the mass of settled sludge added to each vessel and the gas phase volume in the vessel after the sample was added. The reproducibility of the molar gas determination using this manifold system has been established experimentally, and a detailed discussion can be found in Appendix A of the Series I report. The relative standard deviation for quantitative gas phase measurements conducted over a time frame similar to that of the gas generation tests is typically less than $2 \%$.

An atmospheric pressure gauge was attached to the datalogger. The pressure in each system was the sum of atmospheric pressure and the differential pressure between the system internal and external (atmospheric) pressures. An inert cover gas was required to identify product gases and understand the chemical reactions occurring in the settled sludge. Because neon leaks more slowly than helium from the system, it was used as a cover gas. Argon was not used because it served as an indicator of atmospheric contamination. Nitrogen, as will be discussed later, can react with sludge and thus was not a suitable cover gas. The neon was analyzed independently by mass spectrometry and determined to contain no impurities in concentrations significant enough to warrant correction. 
Table 2.7. Masses of Settled Sludge and Vessel Volumes Used in Gas Generation Tests

\begin{tabular}{|l|c|c|c|c|c|}
\hline \multicolumn{1}{|c|}{ System } & KC-1 Un & $\begin{array}{c}\text { KC-1 } \\
\text { Mix }\end{array}$ & $\begin{array}{c}\text { KC-1 } \\
\text { P500 }\end{array}$ & $\begin{array}{c}\text { KC-1 } \\
\text { M500 }\end{array}$ & FE-1 \\
\hline Temperature & $60^{\circ} \mathrm{C}$ & $60^{\circ} \mathrm{C}$ & $80^{\circ} \mathrm{C}$ & $80^{\circ} \mathrm{C}$ & $90^{\circ} \mathrm{C}$ \\
\hline Sample mass, g & 23.75 & 25.61 & 14.15 & 22.30 & 27.00 \\
\hline Gas phase, $\mathrm{ml}$ & 39.83 & 42.43 & 27.70 & 32.71 & 32.15 \\
\hline Vessel total, $\mathrm{ml}$ & 62.40 & 62.96 & 62.37 & 62.45 & 62.44 \\
\hline System & $\mathbf{F E - 3}$ & $\mathbf{F E - 5}$ & $\mathbf{F E - 4 / 6}$ & $\mathbf{K C - 6}$ & $\mathbf{9 6 - 0 6}$ \\
\hline Temperature & $90^{\circ} \mathrm{C}$ & $90^{\circ} \mathrm{C}$ & $90^{\circ} \mathrm{C}$ & $90^{\circ} \mathrm{C}$ & $80^{\circ} \mathrm{C}$ \\
\hline Sample mass, $\mathrm{g}$ & 21.22 & 20.70 & 16.12 & 19.10 & 19.51 \\
\hline Gas phase, $\mathrm{ml}$ & 38.05 & 37.17 & 32.08 & 36.22 & 37.29 \\
\hline Vessel total, $\mathrm{ml}$ & 62.41 & 61.48 & 61.42 & 62.43 & 62.75 \\
\hline
\end{tabular}

\subsubsection{System Startup}

At the start of each run, each system was purged by at least eight cycles of pressurizing with neon at $45 \mathrm{psi}(310 \mathrm{kPa})$ and venting to the atmosphere. The systems were at atmospheric pressure, about $745 \mathrm{~mm} \mathrm{Hg}(99.3 \mathrm{kPa})$, when sealed. The sample portion of the manifold was isolated (valves V1 and V2 closed; see Figure 2.1) for the remainder of the run. The vessels then were heated, and the temperature set points were adjusted to keep the material within $1^{\circ} \mathrm{C}$ of the desired liquid phase temperatures. The gas phase temperatures were measured to be $5^{\circ} \mathrm{C}$ to $25^{\circ} \mathrm{C}$ lower than those of the sample liquid phase.

\subsubsection{Gas Sampling and Analysis}

As necessary during the testing and at the end of each reaction sequence, the vessels were allowed to cool to ambient temperature and then a sample of the gas was taken for mass spectrometry analysis. Gases in the reaction system were assumed to be well mixed. The 304 or 316 stainless steel gas collection bottles were equipped with a valve (Nupro $4 \mathrm{H}$ packless valve with metal seats) and had a volume of approximately $75 \mathrm{ml}$ (about two times the gas phase volume of the reaction vessels). After the bottle was evacuated overnight at high vacuum, it was attached to the gas sample port. Air was removed from the region between valves V2 and V5 (Figure 2.1), using a vacuum pump, and then the gas sample was taken. After the collection bottle was removed, the bottle and sample port were surveyed for radioactive contamination. No contamination was found during these experiments. The reaction vessel was purged again with neon after each sampling event and before the next reaction sequence.

The composition of the gas phase of each reaction vessel during gas sampling was analyzed at the PNNL Mass Spectrometry Facility, using analytical procedure PNNL-98523-284 Rev. 0. The amount of a specific gas formed during heating is given by the mole percent of each gas multiplied by the total moles of gas present in a system. The measured amount of argon in gas samples is an indicator of how much nitrogen and oxygen from air has leaked into the system (the $\mathrm{N}_{2}$ :Ar ratio in air is 83.6:1; the $\mathrm{O}_{2}$ :Ar ratio is 22.4:1). The nitrogen produced or consumed in the vessel is the total nitrogen minus atmospheric nitrogen. A similar calculation is used to correct for oxygen production or consumption. 


\subsection{Gas Generation from KE Basin Sludge Samples}

In each test, gas-tight reaction vessels were loaded with selected KE Basin materials, the gas space purged with neon, and the loaded vessels heated to the selected temperature. Gas samples were taken from the vessels once during the run and again at the end of each run in accordance with the test plan. After the first gas sample was taken from each vessel, the vessel was purged to remove previously generated gases before testing resumed. Gas generation rates were determined for each gas sample, based on the heating time, the gas composition, the total gas quantity in the system from which the sample was taken, and the sludge mass present in each reaction vessel.

Section 3.1 presents the results from the study of the effects of agitation and aeration on the intact (not size-fractionated) KC-1 sludge. Gas generation results for the P500 and M500 (greater than and less than $500 \mu \mathrm{m}$, respectively) fractions of the KC-1 sludge are found in Section 3.2. Results of the gas generation studies of the single-pull core samples FE-1, FE-3, FE-5, and FE-4/6 are presented in Section 3.3. The gas generation results for samples KC-6 and 96-06 are presented in Section 3.4.

\subsection{Gas Generation Results for Mixed and Unmixed KC-1 Canister Sludge at $60^{\circ} \mathrm{C}$ and $95^{\circ} \mathrm{C}$}

Two tests were conducted in which aliquots of $\mathrm{KC}-1$ sludge were heated at $60^{\circ} \mathrm{C}$ for about 300 hours and subsequently heated to $95^{\circ} \mathrm{C}$ for an additional 640 hours. In one test, the sludge was added to the reaction vessel without any agitation (mixing) beyond that required for subsampling and loading the vessel. This test was designated as $\mathrm{KC}-1 \mathrm{Un}$. In the second test, the sludge and supernatant liquid were shaken vigorously in a capped vial for 1 minute, the vial and contents allowed to stand 1 minute without agitation, and the vial opened to allow ingress of fresh air. This sequence was repeated four more times before the sludge slurry was transferred to the test vessel. This test was designated as $\mathrm{KC}-1$ Mix.

In both of these tests, the reaction vessel temperature was increased to $95^{\circ} \mathrm{C}$ to force the reactions to completion so that the quantity of uranium metal present in the initial sludge could be derived. Gas samples were taken after about 470 hours of reaction (including periods at both $60^{\circ} \mathrm{C}$ and $95^{\circ} \mathrm{C}$ ) and at the end of the test (after a further 477 hours at $95^{\circ} \mathrm{C}$ ). The total amounts of gas produced (e.g., $\mathrm{H}_{2}, \mathrm{CO}_{2}, \mathrm{CH}_{4}$ ) became constant with time (Figure 3.1), which suggested that the gas-producing reactions went to completion. As expected, the gas generation rates initially increased when the temperature was increased to $95^{\circ} \mathrm{C}$. However, no significant induction period was observed before the onset of gas generation in either test. The lack of an induction time is in contrast to the behavior observed in the $60^{\circ} \mathrm{C}$ Series I test of uranium-bearing sludge $\mathrm{KC}-2 / 3 \mathrm{P} 250$, in which a $\sim 200$-hour induction period was observed prior to gas generation. The gases produced in the $\mathrm{KC}-2 / 3 \mathrm{P} 250$ experiment were predominantly $\mathrm{H}_{2}$. However, as shown in Section 4.2, the $\mathrm{KC}-1 \mathrm{Un}$ and $\mathrm{KC}-1 \mathrm{Mix}$ gas products were mostly $\mathrm{CO}_{2}$ and the contribution of $\mathrm{H}_{2}$ was less than $1 \%$ of the total gas evolved.

Note in Figure 3.1 that mixing the KC-1 sludge before it was added to the test vessel had no substantial effect on total gas generation. If anything, sample KC-1 Mix produced slightly less gas than sample KC-1 Un. However, KC-1 Mix produced about 10 times more hydrogen than KC-1 Un. Figure 3.1 also shows that most of the reaction occurred after the temperature was boosted to $95^{\circ} \mathrm{C}$. The $\mathrm{KC}-1 \mathrm{Mix}$ test produced about 0.014 moles of gas per kilogram of settled sludge, and the $\mathrm{KC}-1 \mathrm{Un}$ test produced about $0.017 \mathrm{moles} / \mathrm{kg}$ settled sludge. 


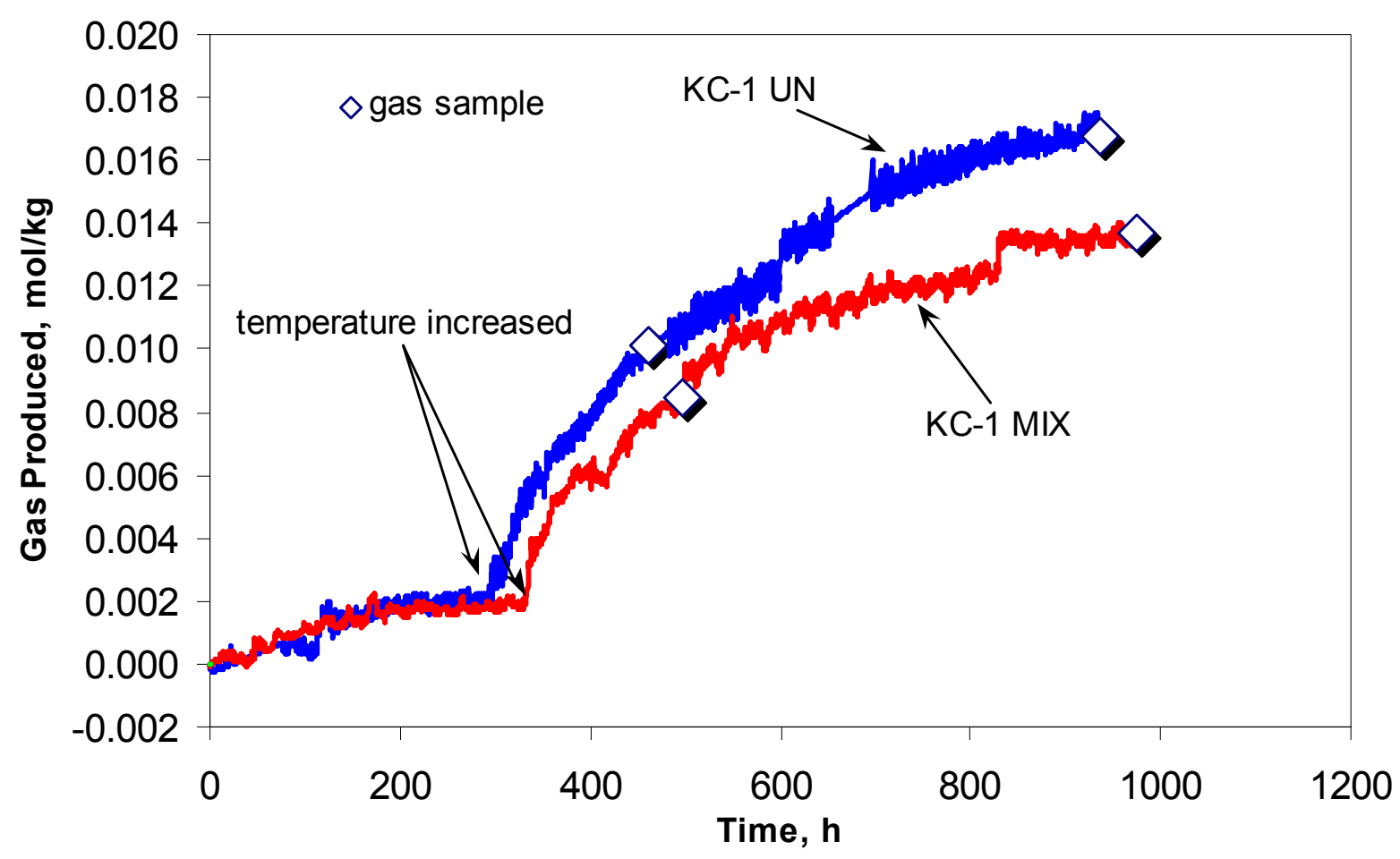

Figure 3.1. Total Gas Generation from KC-1 Mixed (Mix) and Unmixed (Un) Settled Sludge Material at $60^{\circ} \mathrm{C}$ and Completed at $95^{\circ} \mathrm{C}$

The gas sample compositions from the KC-1 Un and KC-1 Mix tests are given in Tables A.1 and A.2 in Appendix A, respectively. Gas samples were analyzed by mass spectrometry. The compositions of the generated gases (derived from the compositions of sampled gas by excluding the neon cover gas, argon, and trace nitrogen and oxygen from atmospheric contamination) are presented and are indicated by shading. For example, if analysis found $80 \% \mathrm{Ne}, 5 \% \mathrm{CO}_{2}$, and $15 \% \mathrm{H}_{2}$, the composition of gas formed by excluding $\mathrm{Ne}$ would be $25 \% \mathrm{CO}_{2}$ and $75 \% \mathrm{H}_{2}$.

The presence of argon in the gas samples was used to indicate atmospheric contamination (air), since it is not present in the cover gas and is not produced by the sludge. Nitrogen could have been generated or consumed by the sludge or could have come from atmospheric contamination. The percent nitrogen actually generated or consumed is given by the percent nitrogen found minus 83.6 times the percent argon in the sample (the ratio of nitrogen to argon in dry air is 83.6). The percent oxygen actually generated or consumed in the samples may be calculated in a method similar to nitrogen. The sum of all percents for a run in Tables A.1 and A.2 may not be exactly $100 \%$, because the values were rounded. The uncertainties in all the entries in these tables are approximately plus or minus 1 in the last digit.

Individual gas generation rates are calculated based on the total moles of gas produced (Figure 3.1) and the generated gas compositions (Tables A.1 and A.2). Tables A.3 and A.4 show the gas generation rates derived in this manner for $\mathrm{KC}-1 \mathrm{Un}$ and $\mathrm{KC}-1$ Mix tests. Because only two gas samples were taken, the rates are averages over extended time periods (i.e., periods including both rapid gas evolution and relative 
quiescence). The rates for the first gas sample also include periods at two different temperatures $\left(60^{\circ} \mathrm{C}\right.$ and $95^{\circ} \mathrm{C}$ ). More detailed consideration of gas composition and generation rates is given in Section 4.2.

\subsection{Gas Generation Results for KC-1 P500 and M500 Canister Sludge at $80^{\circ} \mathrm{C}$ and $95^{\circ} \mathrm{C}$}

Gas generation tests with the P500 and M500 size fractions of the $\mathrm{KC}-1$ canister sludge were conducted at $80^{\circ} \mathrm{C}$ for about 320 hours followed by 643 hours of heating at $95^{\circ} \mathrm{C}$ to force completion of the reactions. The total amount of gas produced became constant at extended heating times (Figure 3.2), indicating that the gas-generating reactions were at, or very near, exhaustion.

Gas samples were taken about 490 hours into the test (gases generated by $\sim 320$ hours at $80^{\circ} \mathrm{C}$ and 166 hours at $\left.95^{\circ} \mathrm{C}\right)$ and again at the completion of heating $\left(477\right.$ hours at $95^{\circ} \mathrm{C}$ only). The gas samples were analyzed by mass spectrometry; the analyzed compositions are given in Tables A.5 and A.6. The net compositions of gases generated (and consumed) are presented in shading below each entry. Argon again was used to indicate atmospheric contamination and as a basis to correct for nitrogen and oxygen consumed or generated by the sludge reactions (see Section 3.1). The sums of all percents in Tables A.5 and A.6 for a gas sample may not be exactly $100 \%$, because the values were rounded.

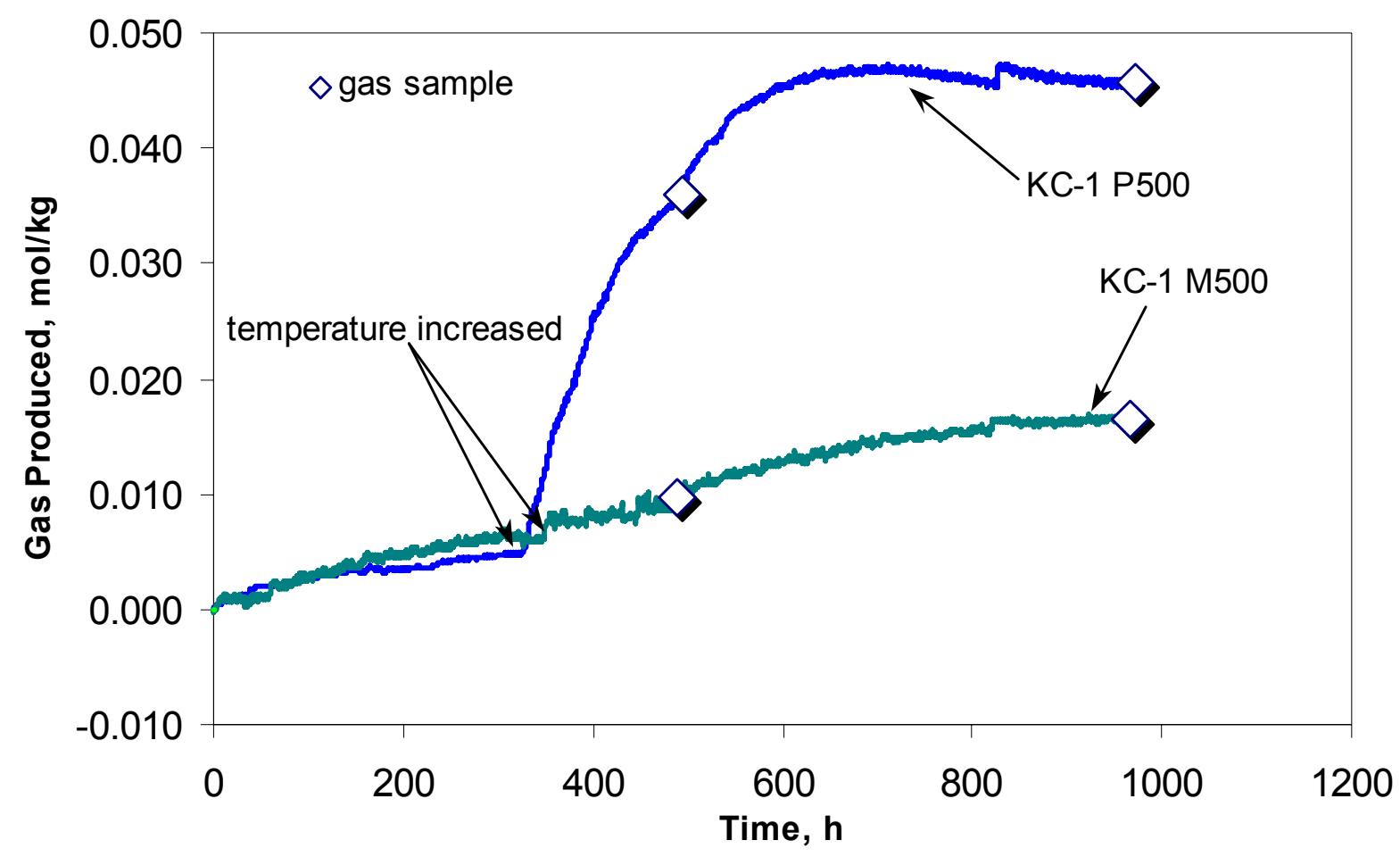

Figure 3.2. Total Gas Generation from KC-1 P500 and M500 (Settled Sludge) at $80^{\circ} \mathrm{C}$ and Completed at $95^{\circ} \mathrm{C}$ 
The individual gas generation rates calculated based on the total moles of gas produced (Figure 3.2) and the gas compositions (Tables A.5 and A.6) are given in Tables A.7 and A.8 for KC-1 P500 and M500, respectively. Because only two gas samples were taken, the rates are averages over extended time periods and the first sample included time at both $80^{\circ} \mathrm{C}$ and $95^{\circ} \mathrm{C}$ temperatures. The specific quantity of gas generated is about three times higher for P500 than for M500. The gas produced by the P500 fraction is about $74 \%$ hydrogen, while the M500 fraction only produced about $0.25 \%$ hydrogen; the balance in both cases is predominantly carbon dioxide. The compositions of the generated gases are considered in more detail in Section 4.3.

\subsection{Gas Generation Results for Single-Pull Core Samples FE-1, FE-3, FE-5, and FE-4/6 at $90^{\circ} \mathrm{C}$ and $95^{\circ} \mathrm{C}$}

Thermal gas generation data were measured for single-pull sludge samples FE-1, FE-3, FE-5, and a composite of FE-4 and FE-6 (FE-4/6) in tests run for about 327 hours at $90^{\circ} \mathrm{C}$ and completed at $95^{\circ} \mathrm{C}$ for an additional 643 hours. The total specific amounts of gas produced versus reaction time were measured for each test and are shown in Figure 3.3. Judging by the flatness of the gas production curves with advanced reaction times, the reactions apparently proceeded to completion for FE-3 and FE-5. Gas samples taken after about 490 hours (reaction at both $90^{\circ} \mathrm{C}$ and $95^{\circ} \mathrm{C}$ ) and at completion (about 970 hours of reaction time entirely at $95^{\circ} \mathrm{C}$ ) were analyzed by mass spectrometry. The mole percent compositions of the sampled gases are given in Tables A.9 through A.12, respectively. The generated gas compositions

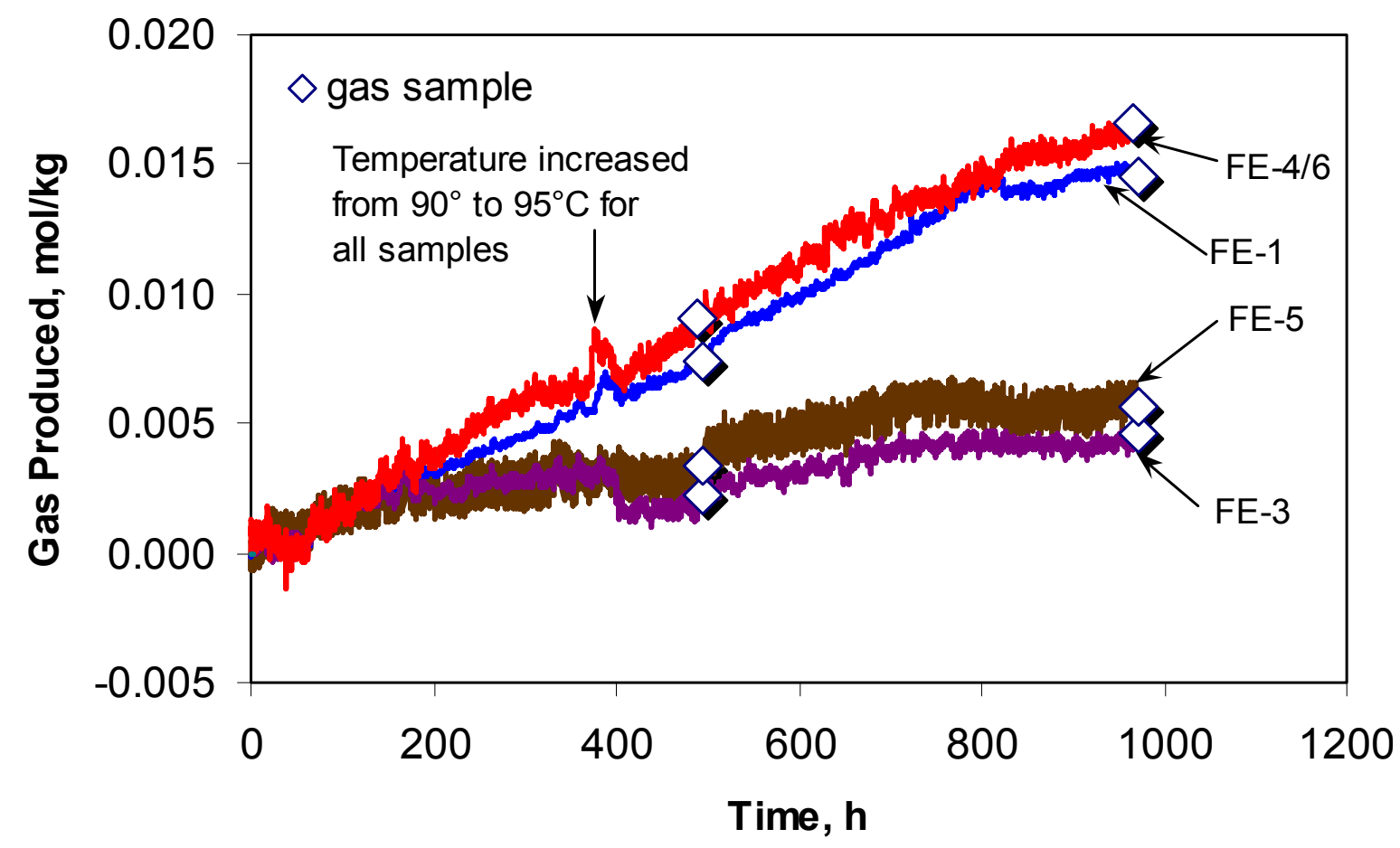

Figure 3.3. Total Gas Generation from FE-1, FE-3, FE-5, and FE-4/6 (Settled Sludge) at $90^{\circ} \mathrm{C}$ and $95^{\circ} \mathrm{C}$ 
are presented (in shaded areas) below the entry for each run. The individual calculated gas generation rates for FE-1, FE-3, FE-5, and FE-4/6 are given in Tables A.13 through A.16, respectively.

The specific amounts of gas generated for FE-1 and FE-4/6 are about three times higher than the amounts observed for FE-3 and FE-5, and are comparable to the specific amounts found for the $\mathrm{KC}-1 \mathrm{Un}, \mathrm{KC}-1$ Mix, and KC-1 M500 sludges (see Sections 3.1 and 3.2). In all cases, the evolved gases for the FE single-pull samples are only $0.3 \%$ to $3 \%$ hydrogen, with the balance predominantly carbon dioxide. The gas compositions are considered further in Section 4.4.

\subsection{Gas Generation Results for KC-6, Ion Exchange Material Sludge, at $90^{\circ} \mathrm{C}$ and $95^{\circ} \mathrm{C}$ and $96-06$ Canister Sludge at $80^{\circ} \mathrm{C}$ and $95^{\circ} \mathrm{C}$}

Gas generation experiments were conducted for KC-6 sludge (IXM) and 96-06 canister sludge. The test with the KC-6 sludge was run at $90^{\circ} \mathrm{C}$ for 327 hours and then completed at $95^{\circ} \mathrm{C}$ for 642 hours. The test with the 96-06 sludge began with 324 hours of heating at $80^{\circ} \mathrm{C}$ and finished with 624 hours of heating at $95^{\circ} \mathrm{C}$. The total specific quantities of gas produced in these tests are shown as a function of reaction time in Figure 3.4. Gas samples were taken after 492 hours (heating at both $90^{\circ} \mathrm{C}$ and $95^{\circ} \mathrm{C}$ ) and again at completion $\left(95^{\circ} \mathrm{C}\right.$ only; 968 hours) for KC-6. Gas samples were taken after 471 hours (heating at $80^{\circ} \mathrm{C}$ and $95^{\circ} \mathrm{C}$ ) and at completion $\left(95^{\circ} \mathrm{C} ; 947\right.$ hours) for the $96-06$ sludge test. The gas samples were analyzed by mass spectrometry, and the results are tabulated in Tables A.17 and A.18, respectively, with generated

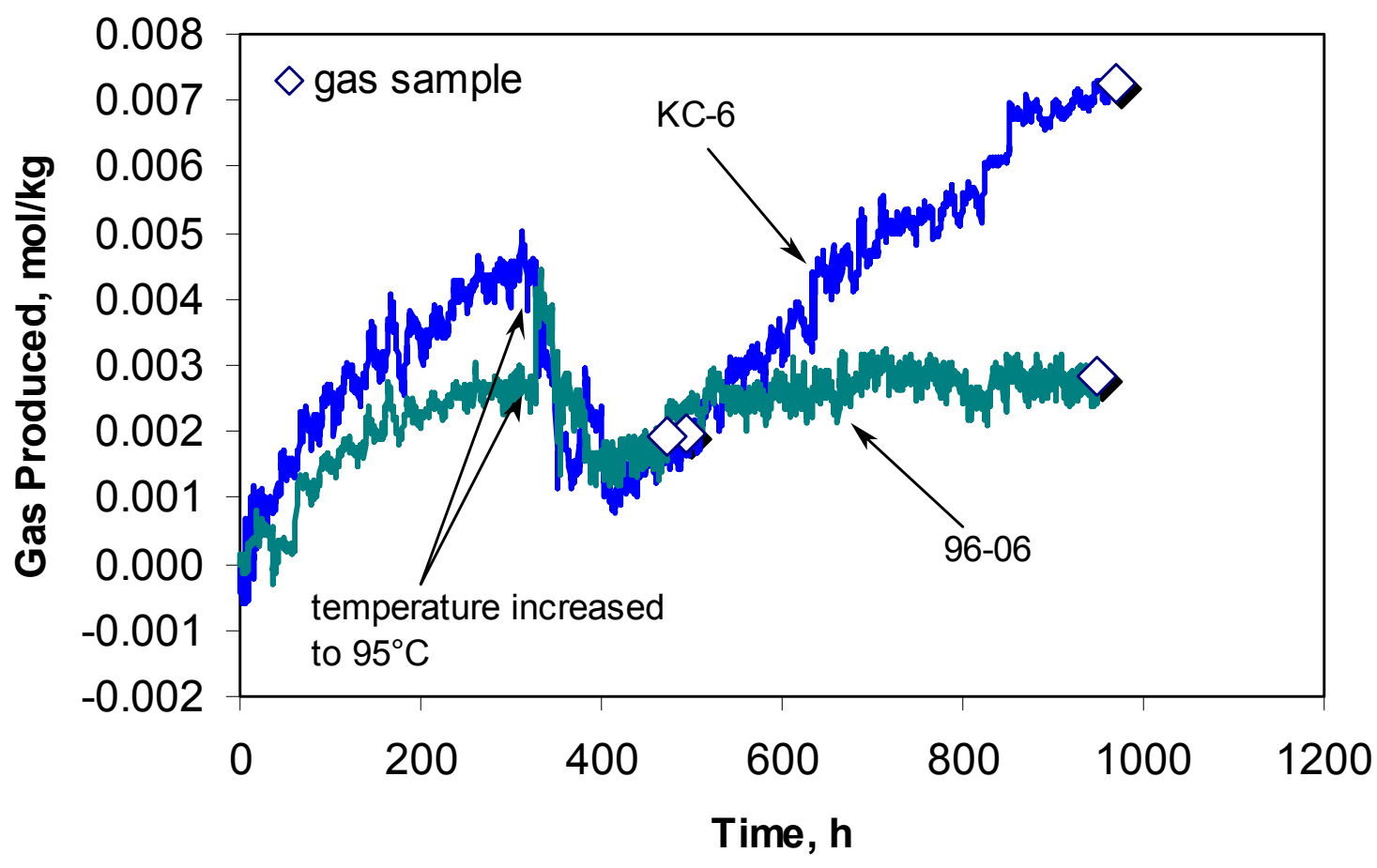

Figure 3.4. Total Gas Generation from KC-6 (Settled Sludge) at $90^{\circ} \mathrm{C}$ and $95^{\circ} \mathrm{C}$ and $96-06$ (Settled Sludge) at $80^{\circ} \mathrm{C}$ and $95^{\circ} \mathrm{C}$ 
gas compositions presented in the shaded areas. The individual gas generation rates for KC-6 and 96-06 are provided in Tables A.19 and A.20, respectively.

The specific amounts of gas produced by KC-6 and 96-06 sludges are relatively low and bracket those generated by the tests with the FE-3 and FE-5 sludges. The product gases are $91 \%$ and $97 \%$ carbon dioxide, respectively, with $8.5 \%$ and $2.3 \%$ hydrogen. The gas compositions are considered further in Section 4.5. 


\subsection{Discussion and Interpretation of Series II Results}

This section presents an evaluation of the results from the gas generation tests performed at various temperatures on samples KC-1, FE-1, FE-3, FE-5, FE-4/6, KC-6, and 96-06, and compares the results with Series I tests (Delegard et al. 2000). Section 4.1 describes the chemical reactions postulated to be responsible for the observed gas generation and consumption phenomenon. Section 4.2 examines in more detail the observations found for the $\mathrm{KC}-1$ unmixed (KC-1 Un) and mixed (KC-1 Mix) tests. The results of the tests with KC-1 P500 and M500 are examined in Section 4.3. Section 4.4 discusses the results from the tests of single-pull core samples FE-1, FE-3, FE-5, and FE-4/6. The results for tests with samples KC-6 and 96-06 are presented in Section 4.5. Section 4.6 gives the overall conclusions drawn from the Series II testing.

\subsection{Gas Generating and Gas Consuming Reactions}

Hydrogen $\left(\mathrm{H}_{2}\right)$; isotopes of the fission product gases, krypton $(\mathrm{Kr})$ and xenon $(\mathrm{Xe})$; methane $\left(\mathrm{CH}_{4}\right)$ and higher hydrocarbons; and carbon dioxide $\left(\mathrm{CO}_{2}\right)$ were observed in the current tests. The same gases were observed in the 1996 gas collection tests associated with KE canister sludge (Makenas et al. 1997) and in the Series I tests using samples KC-2/3, KC-4, and KC-5 (Delegard et al. 2000). The consumption of oxygen $\left(\mathrm{O}_{2}\right)$ and nitrogen $\left(\mathrm{N}_{2}\right)$ from trace atmosphere intrusion observed in many of the present tests also was seen in the prior work. The absolute and relative rates of the appearance and disappearance of these gases give evidence of the underlying chemical reactions thought to be occurring in the sludge. These reactions affect the behavior of the sludge in retrieval, transport, and storage conditions. The postulated chemical reactions are discussed in this section and also are described with varying emphasis in the Series I report.

\subsubsection{Uranium Corrosion and the Roles of Hydrogen, Oxygen, and Nitrogen}

The oxidation of metallic uranium under conditions relevant to $\mathrm{K}$ Basin sludge occurs by several reactions that involve the production and depletion of gases:

$$
\begin{aligned}
& \mathrm{U}+2 \mathrm{H}_{2} \mathrm{O} \rightarrow \mathrm{UO}_{2}+2 \mathrm{H}_{2} \\
& \mathrm{U}+\mathrm{O}_{2} \rightarrow \mathrm{UO}_{2} \\
& \mathrm{U}+0.875 \mathrm{~N}_{2} \rightarrow \mathrm{UN}_{1.75} \\
& \mathrm{U}+1.5 \mathrm{H}_{2} \rightarrow \mathrm{UH}_{3} \\
& \mathrm{UH}_{3}+2 \mathrm{H}_{2} \mathrm{O} \rightarrow \mathrm{UO}_{2}+7 \mathrm{H} \cdot\left(\text { or } 3.5 \mathrm{H}_{2}\right)
\end{aligned}
$$

In aerated waters, uranium metal corrosion occurs largely by Reaction 2 (Montenyohl 1960) and Reaction 3. ${ }^{\text {(a) }}$ However, if the system becomes isolated from the atmosphere (as is the case for the sealed

(a) No explicit mention of the reaction of uranium metal with $\mathrm{N}_{2}$ in aqueous systems was found in the technical literature. The postulated Reaction 3 is based on the observed depletion of $\mathrm{N}_{2}$ from the gas phase in the present tests and the observation of a nonstoichiometric $\mathrm{UN}_{1.75}$ product from reaction of uranium metal with $\mathrm{N}_{2}$ at $200^{\circ} \mathrm{C}$ to $300^{\circ} \mathrm{C}$ (Cordfunke 1969 ). 
test vessels or in confined layers of settled sludge), the direct reaction of uranium with water dominates and hydrogen gas is evolved (Reaction 1). Significantly, though both Reactions 1 and 2 occur in water to produce $\mathrm{UO}_{2}$, the rate of Reaction 2 (in the presence of oxygen) is 30 to 40 times slower than that of the anoxic Reaction 1 (Johnson et al. 1994; Montenyohl 1960). In other words, dissolved oxygen inhibits uranium metal corrosion in water.

Hydrogen accelerates the corrosion of uranium metal in water through the formation, by Reaction 4, of the poorly adherent uranium hydride $\left(\mathrm{UH}_{3}\right)$ corrosion product (Montenyohl 1960). The hydride is observed at the metal surface and within cavities and around inclusions in the metal surface (Tyfield 1988). The $\mathrm{UH}_{3}$ intermediate is unstable in water, forming $\mathrm{UO}_{2}$ and hydrogen atom radicals (Reaction 5). The released hydrogen atoms then may combine to form $\mathrm{H}_{2}$ gas. Alternatively, the hydrogen radicals (and the $\mathrm{H}_{2}$ ), especially if occluded, can interact with the underlying bulk uranium metal to form more $\mathrm{UH}_{3}$ by Reaction 4 and continue the corrosion cycle through Reaction 5. Note that the sum of Reactions 4 and 5 is Reaction 1.

The transition in closed experimental vessels to rapid anoxic corrosion dominated by Reactions 4 and 5 usually is preceded by an induction time. The induction times vary unpredictably, even at experimentally identical conditions (Tyfield 1988; Wilkinson 1962). While rapid corrosion by Reactions 4 and 5 is observed in anoxic conditions, Reaction 1 evidently also occurs during the induction time, though at a much lower rate than observed after the induction time, to provide the hydrogen necessary for Reaction 4. Therefore, uranium reaction with water can occur under two regimes. The first is an initial period of low reaction rate (in the absence of significant free hydrogen and hydride hydrogen concentrations) by Reaction 1; with sufficient hydrogen, the second regime is entered in which uranium corrosion by water occurs at the much higher rate afforded by $\mathrm{UH}_{3}$ mediation (the combined Reactions 4 and 5).

The corrosion rate of uranium by Reactions 4 and 5 is known to follow kinetics that are first order in the uranium metal surface area. An evaluation of data in the technical literature is summarized by the following rate equation:

$$
\log \text { rate }\left(\mathrm{U} \text { weight loss, } \mathrm{mg} / \mathrm{cm}^{2} \cdot \mathrm{hr}\right)=8.505-\frac{3016}{\mathrm{~T}}
$$

where $\mathrm{T}$ is temperature in $\mathrm{K}$ (derived from Reilly 1998). The temperature dependence of this rate equation corresponds to a $13.8 \mathrm{kcal} / \mathrm{mole}$ activation energy. Another review of the studies of uranium corrosion in water presented kinetic data that can be fit to the equation:

$$
\log \text { rate }\left(\mathrm{U} \text { weight loss, } \mathrm{mg} / \mathrm{cm}^{2} \cdot \mathrm{hr}\right)=9.822-\frac{3520}{\mathrm{~T}}
$$

The slope of this equation indicates a 16.1-kcal/mole activation energy (derived from Johnson et al. 1994). [The 16.1-kcal/mole activation energy was incorrectly attributed to Pajunen (1999) in the Summary and Conclusions, Section 4.2.1, and Section 4.6 of the Series I report.] No corrosion rate data to describe the initial slow reaction of uranium metal with water have been found in review of the technical literature.

Review of Uranium Corrosions Reactions Observed in Series I Testing: From the discussion above, uranium corrosion in closed vessels by Reactions 2 and 3 (in the presence of residual $\mathrm{O}_{2}$ and $\mathrm{N}_{2}$ ) and the 
initially slow Reaction 1 with time give way to corrosion by water (Reaction 1) made rapid by $\mathrm{UH}_{3}$ mediation through Reactions 4 and 5. Evidence for this sequence is found in the KC-2/3 P250 (canister sludge composite with particles greater than $250 \mu \mathrm{m}$ ) tests described in the Series I studies. In these tests, seven to nine gas samples each were taken at the $40^{\circ} \mathrm{C}, 60^{\circ} \mathrm{C}$, and $80^{\circ} \mathrm{C}$ test temperatures. Later, the temperatures were boosted to $95^{\circ} \mathrm{C}$ to completely corrode all of the uranium metal. Gas analysis data from Series I then were used to calculate and compare uranium metal corrosion as measured by the gases $\left(\mathrm{H}_{2}, \mathrm{O}_{2}\right.$, and $\left.\mathrm{N}_{2}\right)$ produced and consumed chemically by Reactions 1-3 with uranium metal corrosion, as inferred by Xe fission product gas release (see Section 4.2.2 of this report).

As seen in Figure 4.1 (generated with data from Series I testing), for each temperature, uranium corrosion, as manifested by the sum of the chemical reactions with $\mathrm{H}_{2} \mathrm{O}$ (shown by $\mathrm{H}_{2}$ release), $\mathrm{O}_{2}$, and $\mathrm{N}_{2}$ ("Corr. Gases"), initially lags the uranium corrosion measured by Xe release ("Xe Total"). This interval is greater at lower reaction temperatures. The amounts of uranium corroded, as determined by Xe release and $\mathrm{O}_{2} / \mathrm{N}_{2}$ consumption and $\mathrm{H}_{2}$ production, converge only when about $60 \%$ to $80 \%$ of the uranium has reacted and sufficient $\mathrm{H}_{2}$ is released to the gas phase. Because $97 \%$ or more of the uranium metal corrosion is caused by reaction with water in the $\mathrm{KC}-2 / 3 \mathrm{P} 250$ sludge tests, the corrosion gas delay is almost certainly caused by $\mathrm{H}_{2}$ uptake in the sludge matrix, such as by Reaction 4 to form $\mathrm{UH}_{3}$.

The extent of the combined Reactions 4 and 5 (uranium metal with water to form $\mathrm{H}_{2}$ through $\mathrm{UH}_{3}$ ) may be estimated as the difference between the total uranium reacted as shown by Xe release and the uranium reacted as shown by $\mathrm{O}_{2}$ and $\mathrm{N}_{2}$ consumption in Reactions 2 and 3. The amounts of uranium reacted with water estimated in this way are plotted as "Xe from $\mathrm{H}_{2} \mathrm{O}$ " in Figure 4.1 for the Series I tests with KC-2/3 P250 sludge. The dashed line slopes in Figure 4.1 plotted through these points indicate the rates of Reactions 4 and 5 at the three primary test temperatures. The activation energy for uranium metal corrosion by Reactions 4 and 5, based on these rates plotted in Arrhenius coordinates at the three

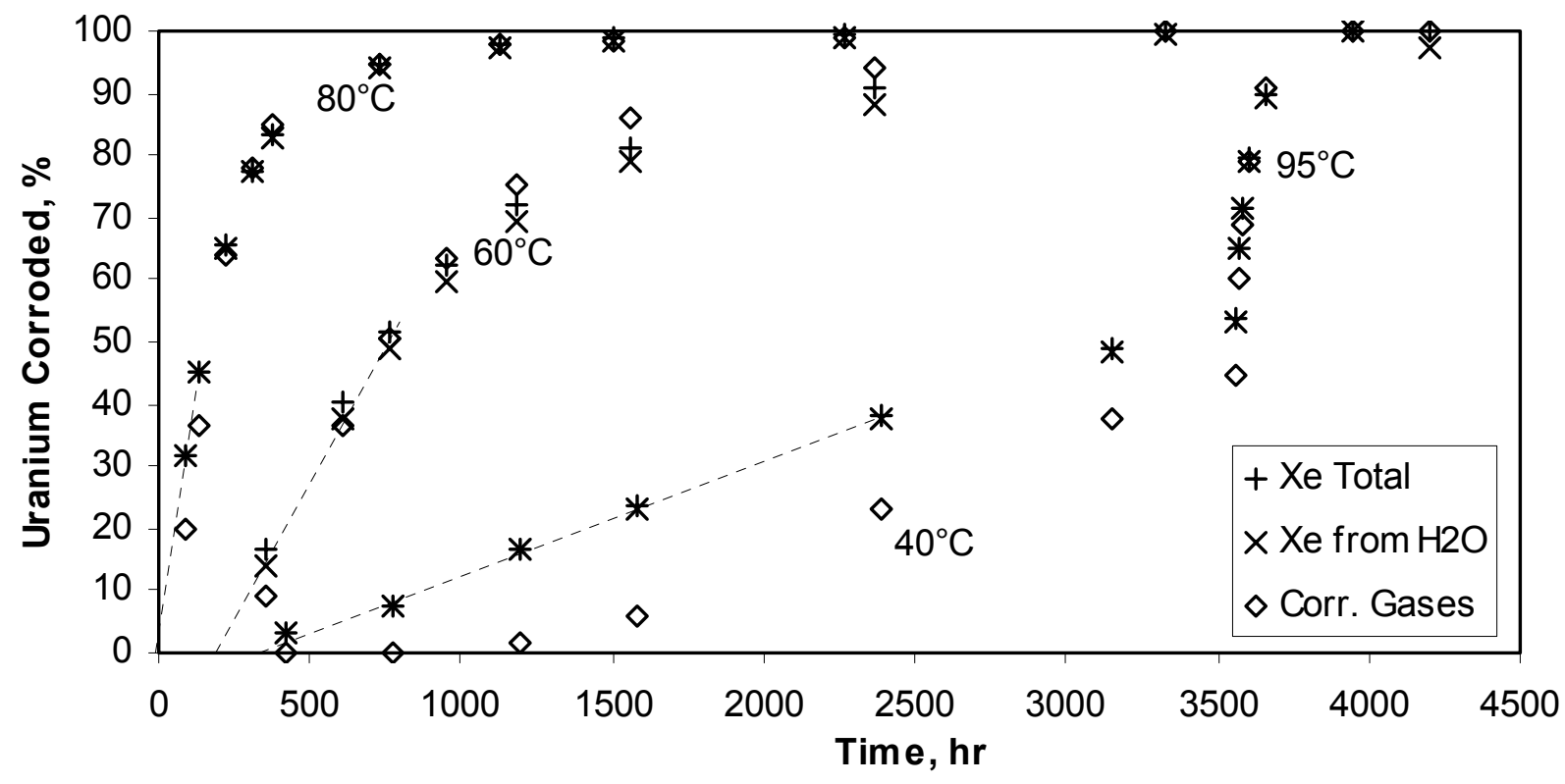

Figure 4.1. Uranium Corrosion in KC-2/3 P250 Series I Small-Scale Tests, as Monitored by Total Xe Release, Xe Released by Uranium Reaction with Water, and Corrosion Gases $\left(\mathrm{H}_{2}\right.$ from $\mathrm{H}_{2} \mathrm{O} ; \mathrm{O}_{2} ;$ and $\left.\mathrm{N}_{2}\right)$ 
temperatures, is $15.8 \mathrm{kcal} / \mathrm{mole}\left(\mathrm{R}^{2}=1.00\right)$. In comparison, activation energies of $15.1-\mathrm{kcal} / \mathrm{mole}$ and $15.8-\mathrm{kcal} / \mathrm{mole}$ values were found based on $\mathrm{H}_{2}$ evolution for the same experiments. The activation energies observed for the KC-2/3 P250 tests thus lie between the 13.8- and 16.1-kcal/mole values for uranium corrosion in water derived by evaluations of the technical literature (Reilly 1998 and Johnson et al. 1994, respectively).

The induction times to onset of the rapid $\mathrm{H}_{2}$-mediated corrosion by Reactions 4 and 5 also can be estimated by analysis of the "Xe from $\mathrm{H}_{2} \mathrm{O}$ " data. The induction times are only approximate because the initial rate of Reaction 1 is not known. For example, of all gas samples taken in the Series I KC-2/3 P250 tests, perhaps only the first gas sample in the $40^{\circ} \mathrm{C}$ test was taken before the full onset of $\mathrm{H}_{2}$-mediated corrosion. The induction times, therefore, are measured as the X-axis intercepts of the linear Xe evolution points between about $10 \%$ and $50 \%$ reaction. The estimated induction times are about 335 hours at $40^{\circ} \mathrm{C}, 186$ hours at $60^{\circ} \mathrm{C}$, and essentially 0 hours at $80^{\circ} \mathrm{C}$. These induction times are lower than the 1340, 205, and 26.9 hours, respectively, estimated from the $\mathrm{H}_{2}$ gas release rate data (Delegard et al. 2000). The differences again reflect the incorporation of $\mathrm{H}_{2}$ in the sludge solids as $\mathrm{UH}_{3}$ or as other species. The negligible induction time for the $80^{\circ} \mathrm{C}$ test is consistent with tests of uranium corrosion in aerated water conducted at $50^{\circ} \mathrm{C}, 60^{\circ} \mathrm{C}, 70^{\circ} \mathrm{C}, 80^{\circ} \mathrm{C}$, and $100^{\circ} \mathrm{C}$ (Wilkinson 1962, pp. 834-835). In the Wilkinson (1962) tests, induction times were observed at the lower temperatures, but no delays in onset of corrosion (as measured by metal weight loss) were evident in the $80^{\circ} \mathrm{C}$ and $100^{\circ} \mathrm{C}$ tests. The induction period has been attributed to the presence of molecular oxygen on the metal surface that blocks the reduction of water to hydrogen (Reaction 1; Tyfield 1988) and to the breakdown of pre-existing protective $\mathrm{UO}_{2}$ layers on the metal surface (Wilkinson 1962). Saturating the water with $\mathrm{H}_{2}$ is found to decrease the induction time (Wilkinson 1962).

Growths in $\mathrm{H}_{2}$ concentration over the experimental periods were not observed in Series II where only two gas samples were taken during each test, and only one test (KC-1 P500) generated significant quantities of $\mathrm{H}_{2}$. However, evolution of $\mathrm{N}_{2}$ and consumption of $\mathrm{O}_{2}$ in the latter stages of several tests gave evidence that uranium nitride $\left(\mathrm{UN}_{1.75}\right)$, formed by Reaction 2 , may have reacted to form uranium dioxide $\left(\mathrm{UO}_{2}\right)$.

\subsubsection{Release of Fission Product Gases}

The existence of the $\mathrm{Kr}$ and $\mathrm{Xe}$ fission products in the generated gases gives qualitative evidence of the corrosion of irradiated uranium metal. This assertion is based on two reasonable suppositions: 1) that until corrosion occurs, the fission gases remain trapped within the solid uranium metal matrix and 2) that the metal corrosion products $\left(\mathrm{UO}_{2}, \mathrm{UH}_{3}\right)$ and other sludge components cannot react with, and thus retain (except through physical entrapment and dissolution in water), the inert $\mathrm{Kr}$ and $\mathrm{Xe}$ gases.

According to burnup calculations by the ORIGEN code, the isotopic ratios and the total $\mathrm{Kr} /$ total Xe mole ratios remain relatively unaffected by exposure. Thus, the $\Sigma \mathrm{Xe} / \Sigma \mathrm{Kr}$ mass ratio only increases slightly, from $\sim 11.6$ to 13.1 (7.4 to 8.3 mole ratio), as burnup increases from 1000 to $3600 \mathrm{MWD} / \mathrm{TeU}$. The $\mathrm{Kr}$ and Xe production in nominal $2900 \mathrm{MWD} / \mathrm{TeU}$ fuel is 0.00016 moles $\mathrm{Kr}$ and 0.00134 moles Xe per mole of uranium, and these values increase almost linearly with exposure (burnup). Thus, if exposure is known, the quantity of $\mathrm{Kr}$ or Xe released by corrosion of uranium metal can be used to determine the quantity of uranium metal. Conversely, the concentrations of $\mathrm{Kr}$ and $\mathrm{Xe}$ in the uranium metal (determined by measuring the products of metal corrosion) can be used to calculate burnup (Equations 8 and 9 were empirically derived by fitting output data from the ORIGEN code): 


$$
\begin{aligned}
& \text { Burnup }(\mathrm{MWD} / \mathrm{TeU})=-9.94 \times 10^{-5}(\mathrm{Xe}, \mathrm{ppmp} \mathrm{U})^{2}+4.87(\mathrm{Xe}, \mathrm{ppmp} \mathrm{U}) \\
& \text { Burnup }(\mathrm{MWD} / \mathrm{TeU})=0.154(\mathrm{Kr}, \mathrm{ppmp} \mathrm{U})^{2}+54.1(\mathrm{Kr}, \text { ppmp U})
\end{aligned}
$$

Applying this technique to determine the irradiation exposure of materials in a sludge sample is imprecise, because the sludge can be generated by a number of different fuel elements that may have had different exposures. Furthermore, the irradiation exposure within any given fuel element differs spatially according to its radial and axial locations (e.g., near the cladding versus deep within the fuel element).

As shown above, the quantities of $\mathrm{Kr}$ and $\mathrm{Xe}$ released by uranium metal corrosion are small. Thus, for sludges with low concentrations of uranium metal, the correspondingly lower quantities of $\mathrm{Kr}$ and $\mathrm{Xe}$ released by uranium corrosion may not be detectable by mass spectrometry. In this situation, the quantities of $\mathrm{Kr}$ and $\mathrm{Xe}$ dissolved in solution or present interstitially in the sludge solids also may become significant. For sludges containing miniscule particles of residual uranium metal, a relatively larger fraction of fission product $\mathrm{Kr}$ or Xe can diffuse out of the metal matrix. These effects, which act in opposite directions, decrease the reliability of obtaining quantitative uranium metal concentration and burnup data based on $\mathrm{Kr}$ and $\mathrm{Xe}$ gas analyses from samples having low metal concentrations.

Based on both $\mathrm{Kr}$ and Xe analyses, an average burnup of $\sim 2800 \mathrm{MWD} / \mathrm{TeU}$ was determined for the $\sim 7.4 \mathrm{wt} \%$ uranium KC-2/3 P250 sludge in the Series I small-scale tests. Correspondingly, the correlation between uranium concentration determined by release of $\mathrm{Kr}$ and $\mathrm{Xe}$ fission product gas and gas formation and consumption by corrosion (Reactions 1-3) for these tests is good. However, other sludge samples tested in Series I were $0.145 \mathrm{wt} \%$ uranium metal or lower. As a result, the correlation between uranium metal concentration as determined by $\mathrm{Kr}$ and $\mathrm{Xe}$ fission product gas release (at nominal $2900 \mathrm{MWD} / \mathrm{TeU}$ exposure) and uranium metal concentration determined by corrosion reactions is more scattered (Figure 4.2). Fewer data are shown for $\mathrm{Kr}$ than for Xe in Figure 4.2 because the approximately eightfold lower concentration of $\mathrm{Kr}$ often is below the mass spectrometric detection limit.

Corresponding data for the results from the Series II tests, also presented in Figure 4.2, show that uranium concentrations as determined by corrosion reactions are $\sim 0.4 \mathrm{wt} \%$ or lower. Though paired $\mathrm{Kr}$ and $\mathrm{Xe}$ data (where they exist) agree well with each other, it is seen that the fission product gases predict uranium metal concentrations as much as 300 times higher than those determined by corrosion reaction gas analyses. Because, as seen in Section 4.1.1, $\mathrm{H}_{2}$ is retained in sludge solids, corrosion gas $\left(\mathrm{O}_{2}, \mathrm{~N}_{2}\right.$, and $\left.\mathrm{H}_{2}\right)$ consumption and release may understate uranium metal concentrations, particularly for low metal concentrations. Therefore, despite uncertainties in "average" fuel burnup and in analyzing $\mathrm{Kr}$ and $\mathrm{Xe}$ at low concentrations, determining uranium metal concentration by $\mathrm{Kr}$ and $\mathrm{Xe}$ release likely is a more accurate measure of uranium metal corrosion, particularly for low apparent uranium metal concentrations in which $\mathrm{H}_{2}$ absorption or reaction can occur. The interpretation of $\mathrm{Kr}$ and $\mathrm{Xe}$ fission product gas data in these Series II studies also includes comparisons of their isotopic distributions to ORIGEN calculations, $\Sigma \mathrm{Xe} / \Sigma \mathrm{Kr}$ ratios, and evaluations of cooling time based on observed ${ }^{85} \mathrm{Kr}$ concentration isotopic ratios and decay. 


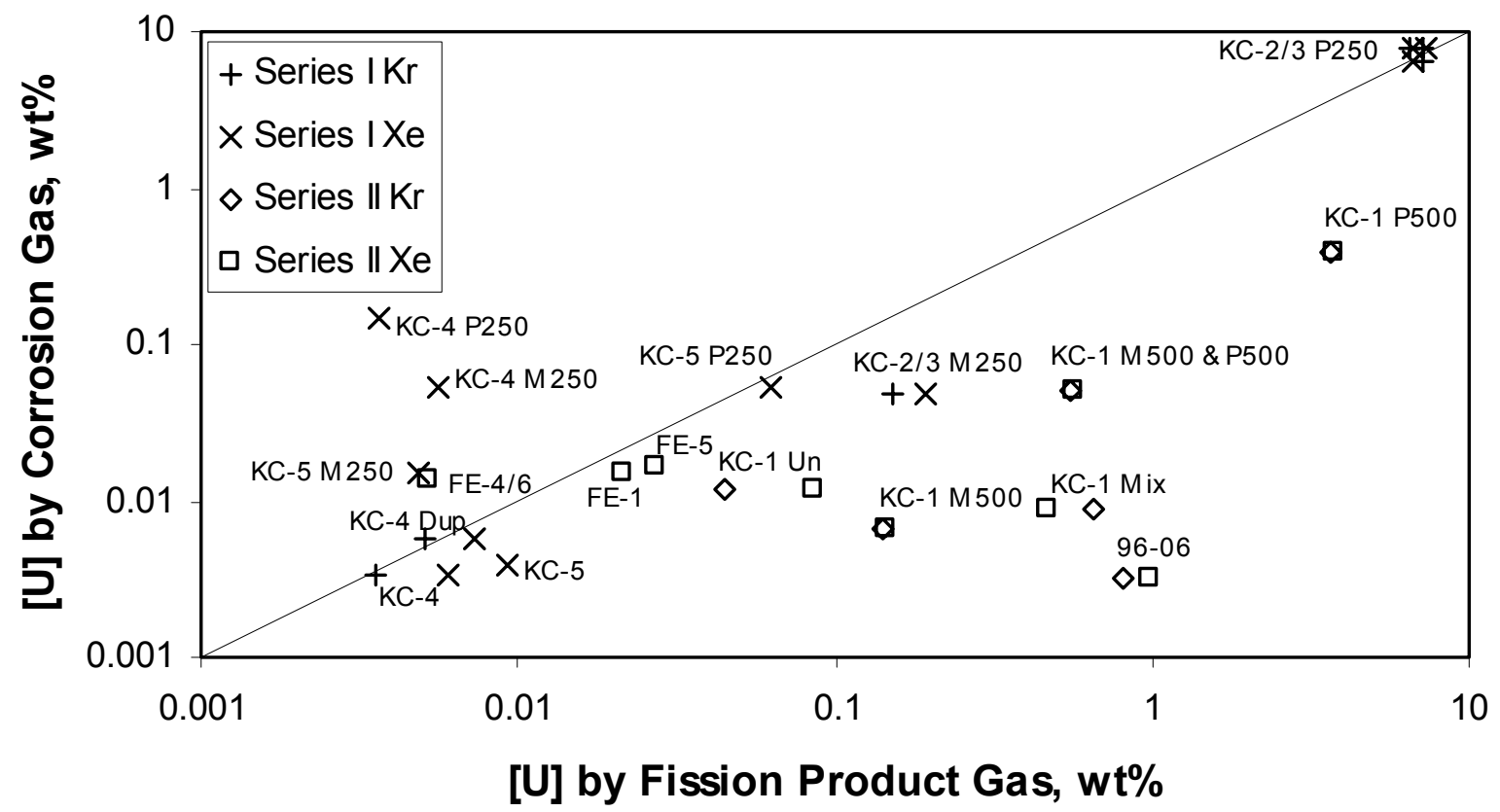

Figure 4.2. Comparison of Uranium Metal Concentrations Determined by Corrosion Reactions and by Release of $\mathrm{Kr}$ and Xe Fission Product Gases at Nominal $2900 \mathrm{MWD} / \mathrm{TeU}$ Irradiation for Series I and Series II Tests

\subsubsection{Creation and Release of Hydrocarbons}

Methane, ethane, and higher hydrocarbons, as well as hydrogen, arise from the reaction of water with carbide carbon in the uranium metal fuel. Hydrogen, methane, ethane, propane, butane, pentane, and hexane have been observed in the reaction of mixtures of uranium metal and uranium monocarbide with water at $80^{\circ} \mathrm{C}$ (Bradley and Ferris 1962,1964$)$. Methane also was observed in corrosion tests of uranium metal with water at $50^{\circ} \mathrm{C}$ (Waber 1956). The carbon content in the metallic uranium fuels stored in the K Basins nominally ranges from 365 to $735 \mathrm{ppm}$ (Weakley 1979). At these low carbon concentrations in the uranium-carbon system, the carbon is present as the compound UC (uranium monocarbide) dispersed within metallic uranium (Wilkinson 1962). Uranium carbide inclusions appear as rectangles or parallelograms $\sim 4 \mu \mathrm{m}$ to $\sim 20 \mu \mathrm{m}$ on a side in photomicrographs of irradiated N Reactor fuel (Marschman et al. 1997) and unirradiated test fuel (Troutner 1960).

Reaction 10 rationalizes the hydrocarbon product distribution observed in Series I testing that arises when the UC contained in the fuel reacts with water:

$$
\mathrm{UC}+2 \mathrm{H}_{2} \mathrm{O} \rightarrow \mathrm{UO}_{2}+0.591 \mathrm{CH}_{4}+0.085 \mathrm{C}_{2} \mathrm{H}_{6}+0.060 \mathrm{C}_{3} \mathrm{H}_{8}+0.015 \mathrm{C}_{4} \mathrm{H}_{10}+0.248 \mathrm{H}_{2}
$$

The $\mathrm{C}_{3}$ and higher hydrocarbons are not discriminated by mass spectrometry in the Series II tests. They are projected to be $\mathrm{C}_{3.2} \mathrm{H}_{8.4}$ on average, based on the observations of Bradley and Ferris $(1962,1964)$, and are represented in Reaction 10 by propane and butane in that proportion. The projected 0.248 moles of hydrogen arising per mole of $\mathrm{UC}$ is a significant contributor to the total gas generated from $\mathrm{UC}$ reaction 
with $\mathrm{H}_{2} \mathrm{O}$. However, this quantity is a negligible $(\sim 0.14 \%)$ addition to the hydrogen generated by reaction of uranium metal with water in nominal 550-ppm carbon fuel.

As in the case of fission product $\mathrm{Kr}$ and $\mathrm{Xe}$, however, the relatively low uranium metal concentrations found in the Series II test sludges produce correspondingly low quantities of hydrocarbon from fuel corrosion. The quantities of hydrocarbon gas evolved in the Series II tests, in fact, generally are much higher (by about 3- to 100-fold) than can arise from corrosion of uranium metal measured by evaluation of $\mathrm{H}_{2}, \mathrm{O}_{2}$, and $\mathrm{N}_{2}$ data. However, as shown in Sections 4.2 through 4.4, the evolved hydrocarbon quantities are consistent with uranium metal concentrations measured by $\mathrm{Xe}$ and $\mathrm{Kr}$ fission product gas release. Nevertheless, at low uranium metal concentrations, the fraction of the hydrocarbon arising from degradation of other reduced (noncarbonate) carbon sources in the sludge may become a significant fraction of the total hydrocarbon. Reduced carbon sources might include organic ion exchange resin, plant and animal debris (e.g., twigs, insects), paper and other cellulose, plastic and rubber used in K Basin operations. The carbon concentrations found as evolved hydrocarbon gas in all the Series II tests range from 0.08 to $18 \mathrm{ppm}$ of the settled sludge mass.

\subsubsection{Carbon Dioxide Generation}

Carbon dioxide is the principal gas generated in 9 of the 10 tests in this series. The $\mathrm{CO}_{2}$ production may be due to the reaction in water of schoepite, $\left(\mathrm{UO}_{2}\right)_{8} \mathrm{O}_{2}(\mathrm{OH})_{12}\left(\mathrm{H}_{2} \mathrm{O}\right)_{12}\left(\right.$ or $\left.4 \mathrm{UO}_{3} \cdot 9 \mathrm{H}_{2} \mathrm{O}\right)$, with calcite, $\mathrm{CaCO}_{3}$, to form the more stable uranium phase, becquerelite, $\mathrm{Ca}\left(\mathrm{UO}_{2}\right)_{6} \mathrm{O}_{4}(\mathrm{OH})_{6}\left(\mathrm{H}_{2} \mathrm{O}\right)_{8}$ (or $\left.\mathrm{CaU}_{6} \mathrm{O}_{19} \cdot 11 \mathrm{H}_{2} \mathrm{O}\right)$ and carbonic acid $\left(\mathrm{H}_{2} \mathrm{CO}_{3}\right)$ :

$$
\begin{aligned}
& 3\left(\mathrm{UO}_{2}\right)_{8} \mathrm{O}_{2}(\mathrm{OH})_{12}\left(\mathrm{H}_{2} \mathrm{O}\right)_{12}+4 \mathrm{CaCO}_{3} \rightarrow 4 \mathrm{Ca}\left(\mathrm{UO}_{2}\right)_{6} \mathrm{O}_{4}(\mathrm{OH})_{6}\left(\mathrm{H}_{2} \mathrm{O}\right)_{8}+4 \mathrm{H}_{2} \mathrm{CO}_{3}+6 \mathrm{H}_{2} \mathrm{O} \\
& \rightarrow 4 \mathrm{Ca}\left(\mathrm{UO}_{2}\right)_{6} \mathrm{O}_{4}(\mathrm{OH})_{6}\left(\mathrm{H}_{2} \mathrm{O}\right)_{8}+10 \mathrm{H}_{2} \mathrm{O}+4 \mathrm{CO}_{2} \uparrow
\end{aligned}
$$

Calcite and a calcium uranium oxide hydrate, $\mathrm{CaU}_{6} \mathrm{O}_{19} \cdot 12 \mathrm{H}_{2} \mathrm{O}$, have been observed by XRD in floor sludge from the KE Basin (Makenas et al. 1996); schoepite and metaschoepite $\left[\left(\mathrm{UO}_{2}\right)_{8} \mathrm{O}_{2}(\mathrm{OH})_{12}\left(\mathrm{H}_{2} \mathrm{O}\right)_{10}\right]$ have been found in canister sludge from the KE Basin (Makenas et al. 1997). Several research groups have studied this reaction and published their findings (Vochten and Van Haverbeke 1990; Sandino et al. 1994; Sowder et al. 1996; Wronkiewicz et al. 1996; Sowder et al. 1999). The salient features of these reported studies are described and compared in the Series I report.

Reaction 11 indicates that $\mathrm{Ca}^{2+}$ substitutes for $2 \mathrm{H}^{+}$to form, in this case, $\mathrm{H}_{2} \mathrm{CO}_{3}$. Therefore, if Reaction 11 proceeds, the solution $\mathrm{pH}$ should decrease. As shown in Table 2.6, little $\mathrm{pH}$ change was noted for any Series II test. Accordingly, the inorganic carbon concentrations in the various settled sludges tested in Series II experiments, based on analysis of $\mathrm{CO}_{2}$ gas generation, are low and ranged from about 20 to $120 \mathrm{ppm}$. Although $\mathrm{CO}_{2}$ was the principal gas product in 9 of the 10 Series II experiments, the specific amounts of $\mathrm{CO}_{2}$ production are 0.002 to $0.02 \mathrm{moles} / \mathrm{kg}$ settled sludge and below the 0.02 to $0.12 \mathrm{moles} / \mathrm{kg}$ observed in the Series I tests with $\mathrm{KC}-2 / 3, \mathrm{KC}-4$, and $\mathrm{KC}-5$ sludges.

\subsection{Gas Analysis for the Mixed and Unmixed KC-1 Canister Sludge at $60^{\circ} \mathrm{C}$ and $95^{\circ} \mathrm{C}$}

The KC-1 canister sludge tests (mixed and unmixed) that began at $60^{\circ} \mathrm{C}$ and ended at $95^{\circ} \mathrm{C}$ produced about 0.017 and 0.014 moles of gas per kg settled sludge, respectively. The initial (and highest) gas 
generation rates in each experiment are similar and are about $2.5 \times 10^{-4}$ moles $/ \mathrm{kg}$-day at $60^{\circ} \mathrm{C}$ and $2.0 \times 10^{-3}$ moles/kg-day at $95^{\circ} \mathrm{C}$ (Figure 3.1).

The quantities of gas produced and consumed in each test are presented in Table 4.1. The gas product was $99.8 \% \mathrm{CO}_{2}$ for test $\mathrm{KC}-1 \mathrm{Un}$ and $95.9 \% \mathrm{CO}_{2}$ for test $\mathrm{KC}-1$ Mix. Hydrogen comprised $0.078 \%$ of the $\mathrm{KC}-1 \mathrm{Un}$ and $0.87 \%$ of the $\mathrm{KC}-1$ Mix product gas. Hydrocarbon and fission product gases comprised the balance of the gas production, and $\mathrm{N}_{2}$ and $\mathrm{O}_{2}$ were consumed in both tests. While the $\mathrm{H}_{2}$ evolution was about nine times higher in the $\mathrm{KC}-1$ Mix test than in the $\mathrm{KC}-1 \mathrm{Un}$ test, the $\mathrm{O}_{2}$ consumption was about 0.5 times lower. Nitrogen consumptions were about equal for both tests. However, $\mathrm{N}_{2}$ consumption is observed only in the first sampling, and $\mathrm{N}_{2}$ was produced in the second sampling. The production of $\mathrm{N}_{2}$ in the second sampling may have been by conversion of the presumed $\mathrm{UN}_{1.75}$ product to $\mathrm{UO}_{2}$ by reaction with water or oxygen.

The quantities of uranium metal corroded as determined by Reaction 1, 2, and 3 stoichiometry are shown in Table 4.2. The uranium metal concentrations in each test are low and comparable (about $0.01 \mathrm{wt} \%$ each). The concentrations also are lower than found in the Series I tests, which ranged from 0.015 to $7.4 \mathrm{wt} \%$ uranium. Agitation and aeration in the KC-1 Mix test resulted in about $20 \%$ of the uranium corrosion to occur by reaction with water (Reaction 1 ); only $\sim 1.7 \%$ of the uranium corroded by Reaction 1 in the nonagitated, $\mathrm{KC}-1$ Un test. The reaction of uranium metal with oxygen is complementary; $38 \mathrm{wt} \%$ of the uranium is corroded by oxygen in the $\mathrm{KC}-1$ Mix test and $65 \mathrm{wt} \%$ in the $\mathrm{KC}-1 \mathrm{Un}$ test. Nitrogen is responsible for $33 \mathrm{wt} \%$ of the uranium corrosion in KC-1 Mix and $42 \mathrm{wt} \%$ in the KC-1 Un test.

The uranium metal concentrations predicted based on $\mathrm{Kr}$ and Xe release (assuming $2900 \mathrm{MWD} / \mathrm{TeU}$ irradiation) are four to seven times higher than predicted based on the corrosion gases for $\mathrm{KC}-1 \mathrm{Un}$, and are 50 to 70 times higher for KC-1 Mix. The higher uranium metal concentrations predicted by the fission product gas release may be attributed in small part to error in the assumed burnup. However, if the burnup were doubled to $6000 \mathrm{MWD} / \mathrm{TeU}$ (the maximum used in N Reactor power operations), the discrepancies would decrease only about a factor of 2 . Another possible explanation is that $\mathrm{Kr}$ and $\mathrm{Xe}$ were retained and present in the sludge before it was added to the test vessels, and both gases were released by heating during testing. However, the quantities of $\mathrm{Kr}$ and $\mathrm{Xe}$ were not inordinately higher in the first sampling, when such outgassing would have occurred, as compared to the second sampling. The most likely cause of the difference is that a substantial amount of the $\mathrm{H}_{2}$ produced by the uranium metal corrosion was not released during the testing despite the prolonged heating. The hydrogen product instead remained in the sludge solids in an unknown form or was consumed by chemically reducing uranium(VI) minerals [e.g., by converting schoepite, $\left(\mathrm{UO}_{2}\right)_{8} \mathrm{O}_{2}(\mathrm{OH})_{12}\left(\mathrm{H}_{2} \mathrm{O}\right)_{12}$, to uranium octoxide, $\mathrm{U}_{3} \mathrm{O}_{8}$, or uraninite, $\mathrm{UO}_{2}$ (Gillies 1958)].

The uranium metal concentrations based on $\mathrm{Kr}$ and $\mathrm{Xe}$ release also show that agitation substantially increased the uranium metal corrosion. The calculated uranium metal concentrations were about nine times higher, on average, for the $\mathrm{KC}-1$ Mix experiment ( $\sim 56 \mathrm{wt} \%$ ) compared with the $\mathrm{KC}-1 \mathrm{Un}$ experiment $(\sim 0.065 \mathrm{wt} \%)$.

The uranium metal content of $\mathrm{KC}-1 \mathrm{Mix}(0.56 \mathrm{wt} \%)$ is considerably lower than the $1.9 \mathrm{wt} \%$ uranium metal content of canister sludge composite KC-2/3 measured in Series I testing. However, while KC-1 and $\mathrm{KC}-2 / 3$ were collected from the $\mathrm{KE}$ Basin at approximately the same time, $\mathrm{KC}-1$ was stored in the hot cells $\left(\sim 32^{\circ} \mathrm{C}\right)$ for about $9^{1 / 2}$ months between the start of Series I and the start of Series II. During this storage period, gas bubbles were observed several times in the $\mathrm{KC}-1$ sample, indicating that uranium 
Table 4.1. Net and Cumulative Quantities of Gas Evolved for $\mathrm{KC}-1 \mathrm{Un}$ and $\mathrm{KC}-1$ Mix at $60^{\circ} \mathrm{C}$ and $95^{\circ} \mathrm{C}$

\begin{tabular}{|c|c|c|c|c|}
\hline \multirow[t]{3}{*}{ Gas } & \multicolumn{4}{|c|}{ Gas Quantities, moles, at Sampling Times } \\
\hline & \multicolumn{2}{|c|}{ KC-1 Un } & \multicolumn{2}{|c|}{ KC-1 Mix } \\
\hline & $459.33 \mathrm{hr}$ & $936.00 \mathrm{hr}$ & $496.33 \mathrm{hr}$ & 973.66 hr \\
\hline \multirow{2}{*}{$\begin{array}{l}\mathrm{CO}_{2} \\
\text { Cumulative } \\
\end{array}$} & 2.93E-04 & $2.20 \mathrm{E}-04$ & $2.53 \mathrm{E}-04$ & $1.56 \mathrm{E}-04$ \\
\hline & $2.93 \mathrm{E}-04$ & $5.14 \mathrm{E}-04$ & $2.53 \mathrm{E}-04$ & 4.09E-04 \\
\hline \multirow{2}{*}{\begin{tabular}{|l|}
$\mathrm{H}_{2}$ \\
Cumulative
\end{tabular}} & $2.24 \mathrm{E}-07$ & $1.79 \mathrm{E}-07$ & $1.80 \mathrm{E}-06$ & $1.93 \mathrm{E}-06$ \\
\hline & $2.24 \mathrm{E}-07$ & $4.03 \mathrm{E}-07$ & $1.80 \mathrm{E}-06$ & $3.73 \mathrm{E}-06$ \\
\hline \multirow{2}{*}{$\begin{array}{l}\mathrm{N}_{2} \\
\text { Cumulative }\end{array}$} & \begin{tabular}{|l|}
$-4.64 \mathrm{E}-06$ \\
\end{tabular} & $1.17 \mathrm{E}-06$ & $-4.80 \mathrm{E}-06$ & $1.34 \mathrm{E}-06$ \\
\hline & $-4.64 \mathrm{E}-06$ & $-3.47 \mathrm{E}-06$ & $-4.80 \mathrm{E}-06$ & $-3.46 \mathrm{E}-06$ \\
\hline \multirow{2}{*}{\begin{tabular}{|l|}
$\mathrm{O}_{2}$ \\
Cumulative
\end{tabular}} & \begin{tabular}{|c|}
$-6.00 \mathrm{E}-06$ \\
\end{tabular} & $-1.81 \mathrm{E}-06$ & $-3.14 \mathrm{E}-06$ & $-4.88 \mathrm{E}-07$ \\
\hline & $-6.00 \mathrm{E}-06$ & $-7.82 \mathrm{E}-06$ & & $-3.62 \mathrm{E}-06$ \\
\hline \multirow{2}{*}{\begin{tabular}{|l|}
$\mathrm{CH}_{4}$ \\
Cumulative \\
\end{tabular}} & 2.04E-07 & 2.18 & 5.14E-06 & $6.99 \mathrm{E}-06$ \\
\hline & $2.04 \mathrm{E}-$ & 4.2 & $5.14 \mathrm{E}$ & $1.21 \mathrm{E}-05$ \\
\hline \multirow{2}{*}{\begin{tabular}{|l|}
$\mathrm{C}_{2} \mathrm{H}_{\mathrm{x}}$ \\
Cumulative
\end{tabular}} & $6.11 \mathrm{E}-08$ & & 4.93E-07 & 4.73E-07 \\
\hline & $6.11 \mathrm{~F}$ & $6.11 \mathrm{E}-08$ & & $9.66 \mathrm{E}-07$ \\
\hline \multirow{2}{*}{$\begin{array}{l}\geq \mathrm{C}_{3} \mathrm{H}_{\mathrm{x}} \\
\text { Cumulative }\end{array}$} & 1.83 & & & $3 \mathrm{E}-08$ \\
\hline & $1.83 \mathrm{E}-08$ & $1.83 \mathrm{E}-08$ & $1.07 \mathrm{E}-07$ & $1.89 \mathrm{E}-07$ \\
\hline \multirow{2}{*}{\begin{tabular}{|l|}
$\sum \mathrm{C}_{\mathrm{y}} \mathrm{H}_{\mathrm{x}} \mathrm{C}$ \\
Cumulative
\end{tabular}} & $3.84 \mathrm{E}$ & & 6.46 & $8.20 \mathrm{E}-06$ \\
\hline & 3.84 & $6.02 \mathrm{E}-07$ & $6.46 \mathrm{E}-06$ & $1.47 \mathrm{E}-05$ \\
\hline \multirow{2}{*}{$\begin{array}{l}{ }^{83} \mathrm{Kr} \\
\text { Cumulative }\end{array}$} & $6.11 \mathrm{E}-10$ & $3.97 \mathrm{E}-10$ & $1.28 \mathrm{E}-08$ & 4.11E-09 \\
\hline & $6.11 \mathrm{E}-10$ & $1.01 \mathrm{E}-09$ & $1.28 \mathrm{E}-08$ & $1.70 \mathrm{E}-08$ \\
\hline \multirow{2}{*}{$\begin{array}{l}{ }^{48} \mathrm{Kr} \\
\text { Cumulative }\end{array}$} & $1.02 \mathrm{H}$ & $7.94 \mathrm{E}-10$ & $1.71 \mathrm{E}-08$ & $1.03 \mathrm{E}-08$ \\
\hline & $1.02 \mathrm{E}-09$ & $1.81 \mathrm{E}-09$ & $1.71 \mathrm{E}-08$ & $2.74 \mathrm{E}-08$ \\
\hline \multirow{2}{*}{$\begin{array}{l}{ }^{85} \mathrm{Kr} \\
\text { Cumulative }\end{array}$} & & $5.96 \mathrm{E}-11$ & $1.28 \mathrm{E}-09$ & $8.23 \mathrm{E}-10$ \\
\hline & $0.00 \mathrm{E}+00$ & E-11 & $1.28 \mathrm{E}-09$ & $2.11 \mathrm{E}-09$ \\
\hline \multirow{2}{*}{$\begin{array}{l}{ }^{86} \mathrm{Kr} \\
\text { Cumulative }\end{array}$} & $1.63 \mathrm{E}-09$ & $1.39 \mathrm{E}-09$ & $2.78 \mathrm{E}-08$ & $1.85 \mathrm{E}-08$ \\
\hline & $1.63 \mathrm{E}-09$ & $3.02 \mathrm{E}-09$ & $2.78 \mathrm{E}-08$ & 4.64E-08 \\
\hline \multirow{2}{*}{\begin{tabular}{|l|}
$\mathrm{Kr}$ \\
Cumulative
\end{tabular}} & $3.26 \mathrm{E}-09$ & 2.64E-09 & 5.91E-08 & $3.37 \mathrm{E}-08$ \\
\hline & $3.26 \mathrm{E}-09$ & $5.90 \mathrm{E}-09$ & 5.91E-08 & $9.28 \mathrm{E}-08$ \\
\hline \multirow{2}{*}{$\begin{array}{l}{ }^{130} \mathrm{Xe} \\
\text { Cumulative }\end{array}$} & & & & $6.17 \mathrm{E}-11$ \\
\hline & $0.00 \mathrm{E}+00$ & $0.00 \mathrm{E}+00$ & $0.00 \mathrm{E}+00$ & $6.17 \mathrm{E}-11$ \\
\hline \multirow{2}{*}{$\begin{array}{l}{ }^{131} \mathrm{Xe} \\
\text { Cumulative }\end{array}$} & $1.02 \mathrm{E}-08$ & $3.97 \mathrm{E}-09$ & $4.07 \mathrm{E}-08$ & $2.06 \mathrm{E}-08$ \\
\hline & $1.02 \mathrm{E}-08$ & $1.42 \mathrm{E}-08$ & $4.07 \mathrm{E}-08$ & $6.13 \mathrm{E}-08$ \\
\hline \multirow{2}{*}{$\begin{array}{l}{ }^{132} \mathrm{Xe} \\
\text { Cumulative }\end{array}$} & $1.02 \mathrm{E}-08$ & $5.96 \mathrm{E}-09$ & $6.21 \mathrm{E}-08$ & $3.29 \mathrm{E}-08$ \\
\hline & $1.02 \mathrm{E}-08$ & $1.61 \mathrm{E}-08$ & $6.21 \mathrm{E}-08$ & $9.50 \mathrm{E}-08$ \\
\hline \multirow{2}{*}{$\begin{array}{l}{ }^{134} \mathrm{Xe} \\
\text { Cumulative }\end{array}$} & $1.63 \mathrm{E}-08$ & $9.93 \mathrm{E}-09$ & $9.85 \mathrm{E}-08$ & $5.76 \mathrm{E}-08$ \\
\hline & $1.63 \mathrm{E}-08$ & $2.62 \mathrm{E}-08$ & $9.85 \mathrm{E}-08$ & $1.56 \mathrm{E}-07$ \\
\hline \multirow{2}{*}{$\begin{array}{l}{ }^{136} \mathrm{Xe} \\
\text { Cumulative }\end{array}$} & $2.04 \mathrm{E}-08$ & $1.39 \mathrm{E}-08$ & $1.43 \mathrm{E}-07$ & $8.23 \mathrm{E}-08$ \\
\hline & $2.04 \mathrm{E}-08$ & $3.43 \mathrm{E}-08$ & $1.43 \mathrm{E}-07$ & $2.26 \mathrm{E}-07$ \\
\hline \multirow{2}{*}{\begin{tabular}{|l|}
$\Sigma \mathrm{Xe}$ \\
Cumulative
\end{tabular}} & $5.70 \mathrm{E}-08$ & $3.38 \mathrm{E}-08$ & $3.45 \mathrm{E}-07$ & $1.93 \mathrm{E}-07$ \\
\hline & $5.70 \mathrm{E}-08$ & $9.08 \mathrm{E}-08$ & $3.45 \mathrm{E}-07$ & $5.38 \mathrm{E}-07$ \\
\hline
\end{tabular}


Table 4.2. Reacted Metallic Uranium Calculated from Gas Generation and Consumption Reactions in KC-1 Un and KC-1 Mix Tests

\begin{tabular}{|c|c|c|}
\hline \multirow{2}{*}{ Reaction } & U Reacted Based on Various Reactions, moles \\
\cline { 2 - 3 } & KC-1 Un & KC-1 Mix \\
\hline $\begin{array}{c}\text { Settled Sludge } \\
\text { Mass in Test, } g\end{array}$ & 23.75 & 25.61 \\
\hline $\begin{array}{c}\text { Reaction 1 } \\
\mathrm{U}+2 \mathrm{H}_{2} \mathrm{O} \rightarrow \mathrm{UO}_{2}+2 \mathrm{H}_{2}\end{array}$ & $2.01 \mathrm{E}-7$ & $1.87 \mathrm{E}-6$ \\
\hline $\begin{array}{c}\text { Reaction } 2 \\
\mathrm{U}+\mathrm{O}_{2} \rightarrow \mathrm{UO}_{2}\end{array}$ & $7.82 \mathrm{E}-6$ & $3.62 \mathrm{E}-6$ \\
\hline $\begin{array}{c}\text { Reaction } 3 \\
\mathrm{U}+0.875 \mathrm{~N}_{2} \rightarrow \mathrm{UN} \mathrm{N}_{1.75}\end{array}$ & $3.96 \mathrm{E}-6$ & $3.95 \mathrm{E}-6$ \\
\hline $\begin{array}{c}\text { Total Moles } \mathrm{U} \\
\left(\sum \text { Reactions } 1-3\right)\end{array}$ & $1.20 \mathrm{E}-5$ & $9.44 \mathrm{E}-6$ \\
\hline $\begin{array}{c}\mathrm{U} \text { metal, wt\% } \\
\text { settled sludge, } \\
\text { Reactions 1-3 }\end{array}$ & 0.012 & 0.00877 \\
\hline $\begin{array}{c}\mathrm{U} \text { metal, wt } \% \\
\text { settled sludge, } \mathrm{Kr}\end{array}$ & 0.0446 & 0.651 \\
\hline $\begin{array}{c}\mathrm{U} \text { metal, } \mathrm{wt} \% \\
\text { settled sludge, } \mathrm{Xe}\end{array}$ & 0.0852 & 0.468 \\
\hline
\end{tabular}

metal was reacting. To consider the uranium metal content of $\mathrm{KC}-1$ on a similar basis as that of $\mathrm{KC}-2 / 3$, the uranium metal that corroded during the $91 / 2$-month storage period must be accounted for. Assuming that the initial uranium metal particles in $\mathrm{KC}-1$ were the same size as those in $\mathrm{KC}-2 / 3$, by using Equation 6 (rate equation in Section 4.1.1) it can be shown that $\mathrm{KC}-1$ contained $\sim 2.4 \mathrm{wt} \%$ uranium metal at the start of the Series I tests (Appendix B).

The $\mathrm{Kr}$ and $\mathrm{Xe}$ isotope ratios observed in the product gas are similar to the ratios that are expected based on burnup calculations by the ORIGEN code (Table 4.3). The lower relative quantity of ${ }^{85} \mathrm{Kr}$ found in the present tests can be attributed to radioactive decay. The decrease in ${ }^{85} \mathrm{Kr}$ abundance indicates a cooling time since discharge of about 17 or 30 years for KC-1 Mix and KC-1 Un, respectively. While these times should be identical because they are derived from $\mathrm{Kr}$ gases arising from the same sludge, they are consistent with $\mathrm{N}$ Reactor last being at power $\sim 14$ years ago (1986). The Xe:Kr mole ratios for the two tests are expected to be about 8.2:1 (13:1 mass ratio), according to ORIGEN calculations, and are relatively insensitive to irradiation dose in the normal $\mathrm{N}$ Reactor fuel burnup range of 1000 to $3600 \mathrm{MWD} / \mathrm{TeU}$. The divergent 15.4 and 5.8 mole ratios observed for KC-1 Un and KC-1 Mix, respectively, indicate variability in gas composition perhaps caused by difficulties in measuring near the detection limit.

Methane, ethane, and higher hydrocarbons were found in gases generated during the KC-1 Un and KC-1 Mix tests. As discussed in Section 4.1, because of the low uranium metal concentrations found in the Series II tests, the concentrations of carbon in the uranium metal fuel cannot reliably be determined by comparing the quantity of total carbon in the hydrocarbon gas products (Table 4.1) to the total uranium corroded (Table 4.2). Such calculations show the carbide concentrations in KC-1 Un and KC-1 Mix to be 
Table 4.3. Isotope Ratios for KC-1 Un and KC-1 Mix Tests

\begin{tabular}{|c|c|c|c|}
\hline \multirow{2}{*}{ Gas } & \multicolumn{2}{|c|}{ Isotopic Composition, atom\% } & \multirow{2}{*}{ ORIGEN ${ }^{(\mathbf{a})}$} \\
\cline { 2 - 3 } & KC-1 Un & KC-1 Mix & \\
\hline${ }^{83} \mathrm{Kr}$ & 17.1 & 18.3 & 13.3 \\
\hline${ }^{84} \mathrm{Kr}$ & 30.7 & 29.5 & 28.3 \\
\hline${ }^{85} \mathrm{Kr}$ & 1.0 & 2.3 & 6.8 \\
\hline${ }^{86} \mathrm{Kr}$ & 51.2 & 49.9 & 51.5 \\
\hline${ }^{130} \mathrm{Xe}$ & 0.0 & 0.0 & 0.05 \\
\hline${ }^{131} \mathrm{Xe}$ & 15.6 & 11.4 & 10.7 \\
\hline${ }^{132} \mathrm{Xe}$ & 17.8 & 17.7 & 18.0 \\
\hline${ }^{134} \mathrm{Xe}$ & 28.9 & 29.0 & 28.0 \\
\hline${ }^{136} \mathrm{Xe}$ & 37.7 & 41.9 & 43.2 \\
\hline $\mathrm{Xe}: \mathrm{Kr}$ & 15.4 & 5.8 & 8.2 \\
\hline
\end{tabular}

(a) ORIGEN2 calculation for N Reactor MkIV fuel at $2921 \mathrm{MWD} / \mathrm{TeU}$; ratios change $<3 \%$ relative at lower burnups; ${ }^{85} \mathrm{Kr}$ has a 10.76 -year half-life.

2540 and 78400 parts per million parts (ppmp) uranium metal (based on Reactions 1-3), respectively, and well above the expected carbon concentration of $\sim 550 \mathrm{ppm}$ uranium (Weakley 1979). However, if the uranium metal concentration is based on the fission product gas analyses, the carbide concentrations, about 520 and 1260 ppmp uranium metal for KC-1 Un and KC-1 Mix, are near expectations.

The carbon evolved as hydrocarbon gases comprises about 0.305 and $6.88 \mathrm{ppm}$, respectively, of the starting sludge mass; 70 to $80 \mathrm{wt} \%$ of the carbon is present as methane. The $\sim 20$-fold higher concentration of evolved hydrocarbon gas in the KC-1 Mix test mostly is attributed to the ninefold greater uranium corrosion as shown by $\mathrm{Kr}$ and Xe release. The additional factor of 2 higher hydrocarbon concentration suggests that agitation also may have aided the decomposition of the carbonaceous debris in the sludge by attrition. This explanation remains speculative, however.

Carbon dioxide comprises $99.8 \%$ and $96 \%$ of the gas generated from the KC-1 Un and KC-1 Mix sludge, respectively. The concentrations of inorganic carbon that evolved as carbon dioxide are similar (111 and $73 \mathrm{ppm}$, settled sludge basis) for KC-1 Un and KC-1 Mix. One potential source of $\mathrm{CO}_{2}$ is through Reaction 11 to form becquerelite from schoepite and calcite. If so, calcium ion (from calcite or other sources) rather than schoepite is the limiting reagent in these tests, given the high uranium and low calcium concentrations in the KC-1 material (Table 2.4). The solution $\mathrm{pH}$ was not appreciably altered by reaction (Table 2.6); in the absence of buffering, a $\mathrm{pH}$ decrease would be expected if Reaction 11 occurred. Nevertheless, the inferred inorganic carbon concentrations are consistent with the 5.36- to 1990-ppm inorganic carbon concentrations observed previously in KE floor and Weasel Pit as-settled sludge (Makenas et al. 1996). The inorganic carbon concentration in KC-1 sludge has not been measured directly nor have XRD measurements been made to identify phases participating in Reaction 11.

If the $\mathrm{CO}_{2}$ arises from the reaction of solid phase calcite and schoepite (Reaction 11), and thus involves the disappearance of these solid phases, the kinetics may be surface-area-dependent and subject to an inverse cubic rate law similar to that described in Section 4.6 of the Series I report for uranium metal 
corrosion. ${ }^{(a)}$ Accordingly, total gas generation data for the $\mathrm{KC}-1 \mathrm{Un}$ and $\mathrm{KC}-1$ Mix tests at $95^{\circ} \mathrm{C}$ were plotted in accordance with a shrinking core model. Data from the first several hours following the temperature elevation to $95^{\circ} \mathrm{C}$ were not used because of exsolution of gas dissolved during the time at the lower hot cell temperature.

The inverse cubic relationship plots for the $95^{\circ} \mathrm{C}$ data from $\mathrm{KC}-1 \mathrm{Un}$ and $\mathrm{KC}-1$ Mix tests are shown in Figure 4.3. Also given on the plots are the equations for the best-fit line through the data and the resulting correlation coefficient, $\mathrm{R}^{2}$. To the extent of measurement accuracy, the reactions follow the inverse cubic rate law to $90 \%$ or greater reaction completion [i.e., $(1-\mathrm{f})^{1 / 3}<0.4$ ].

Similar interpretations of the $\mathrm{CO}_{2}$ generation data were made in the Series I tests for minus $250-\mu \mathrm{m}$ canister sludge (KC-2/3 M250), and plus and minus $250-\mu \mathrm{m}$ floor sludges (KC-4 M250, KC-4 P250, $\mathrm{KC}-5 \mathrm{M} 250$, and $\mathrm{KC}-5 \mathrm{P} 250$ ) reacted at $95^{\circ} \mathrm{C}$. As in the prior tests, the variability ("noise") of the data for both tests in Series II increases with reaction time. This is expected because the absolute rate of gas production decreases at advanced times and becomes more subject to random pressure and temperature fluctuations. The KC-1 Un and KC-1 Mix tests show rates (i.e., $\mathrm{k}^{\prime} / \mathrm{r}_{0}$ or $\mathrm{k} / \mathrm{r}_{0} \rho$ ) of (1.02 and $1.13) \times 10^{-3} /$ hour at $95^{\circ} \mathrm{C}$ that are within the range observed for the Series I tests $\left[(0.74\right.$ to 1.22$) \times 10^{-3} /$ hour at $\left.95^{\circ} \mathrm{C}\right]$.

Because the rate-determining mineral (calcite or schoepite in the case of Reaction 11), the associated densities of the minerals, and the mass-specific rates $\mathrm{k}$ or k' are unknown, the nominal particle size of the rate-determining material cannot be determined. However, the consistency of the slopes suggests that the same material, of essentially the same initial particle size, controls the $\mathrm{CO}_{2}$-generating reaction rate in the Series II (KC-1) and Series I (KC-2/3, KC-4, and KC-5) tests. Because the original test materials arose from diverse areas of the KE Basin (floor, near the canisters, and within the canisters), the ratedetermining reactant is broadly distributed, though with varying concentrations, in the KE Basin.

\subsection{Gas Analysis for KC-1 P500 and M500 Canister Sludge at $80^{\circ} \mathrm{C}$ and $95^{\circ} \mathrm{C}$}

The KC-1 P500 and M500 canister sludge tests that began at $80^{\circ} \mathrm{C}$ (about 330 hours) and ended at $95^{\circ} \mathrm{C}$ (643 hours) produced about 0.045 and 0.016 moles of gas per $\mathrm{kg}$ settled sludge, respectively. The latter value is similar to that observed for both the KC-1 Un and KC-1 Mix tests reported in Section 4.2. The initial (and highest) gas generation rates at $80^{\circ} \mathrm{C}$ in each experiment are about $5.6 \times 10^{-4} \mathrm{moles} / \mathrm{kg}$-day.

(a) The kinetics of the reaction of a spherical particle or a cube (or collection of equal-sized spherical or cubic particles) may be expressed analytically for reactions whose rates are proportional to the instantaneous surface area of the solid being consumed by reaction. The relevant rate law for spheres or cubes (as derived in Delegard et al. 2000) has the following inverse cubic dependence:

$$
(1-\mathrm{f}) \frac{1}{3}=1-\frac{\mathrm{kt}}{\mathrm{r}_{0} \rho}=1-\frac{\mathrm{k}^{\prime} \mathrm{t}}{\mathrm{r}_{0}}
$$

in which $\mathrm{f}$ is the fraction reacted at time $\mathrm{t}, \mathrm{r}_{0}$ is the initial radius in $\mu \mathrm{m}, \rho$ is the material density in $\mu \mathrm{g} / \mu \mathrm{m}^{3}$, and $\mathrm{k}$ is the areal reaction rate expressed in $\mu \mathrm{g} / \mu \mathrm{m}^{2}$-hour. Dividing the areal reaction rate, $\mathrm{k}$, by the material density, $\rho$, gives $\mathrm{k}^{\prime}$, the linear penetration rate in $\mu \mathrm{m} /$ hour. A plot of $(1-\mathrm{f})^{1 / 3}$ versus time (in hours) has a slope of $\mathrm{k}^{1} / \mathrm{r}_{0}\left(\right.$ or $\left.\mathrm{k} / \mathrm{r}_{0} \rho\right)$ and intercept on the vertical axis of 1 . 


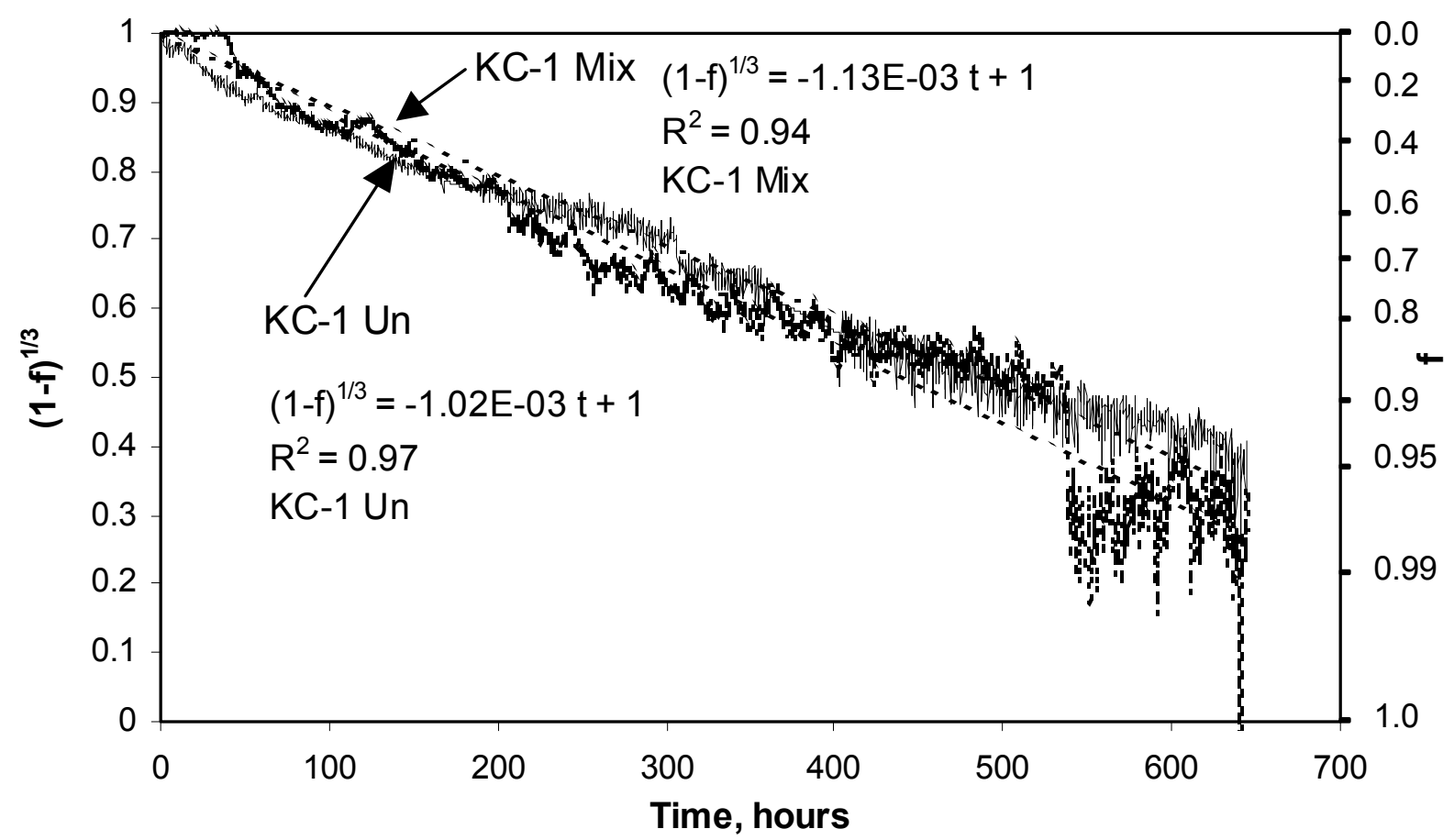

Figure 4.3. Inverse Cubic Function $\mathrm{CO}_{2}$ Generation Kinetics Plot in the $\mathrm{KC}-1 \mathrm{Mix}$ and $\mathrm{KC}-1 \mathrm{Un}$ Tests at $95^{\circ} \mathrm{C}$

This compares with $2.5 \times 10^{-4}$ moles/kg-day observed for the $\mathrm{KC}-1 \mathrm{Un}$ and $\mathrm{KC}-1$ Mix sludges at $60^{\circ} \mathrm{C}$. The KC-1 P500 sludge gas generation rate increased promptly when the temperature was elevated to $95^{\circ} \mathrm{C}$ and reached a maximum value of about $9.5 \times 10^{-3}$ moles/kg-day; the $\mathrm{KC}-1 \mathrm{M} 500$ rate remained relatively unchanged (except for some $\mathrm{CO}_{2}$ exsolution at the temperature excursion and subsequently at sampling) when the temperature was raised to $95^{\circ} \mathrm{C}$ (Figure 3.2). ${ }^{\text {(a) }}$ Judging by the flatness in the latter stages of Figure 3.2, the gas generation reactions apparently reached completion in each test.

The quantities of gas generated and consumed in each test are listed in Table 4.4 and show $\mathrm{CO}_{2}$ to comprise $23 \%$ and $\mathrm{H}_{2} 74 \%$ of the $\mathrm{KC}-1 \mathrm{P} 500$ gas (the balance is hydrocarbons, $\mathrm{Kr}$, and $\mathrm{Xe}$ ). The $\mathrm{KC}-1$ M500 product gas is more like that observed for the $\mathrm{KC}-1 \mathrm{Un}$ and $\mathrm{KC}-1 \mathrm{Mix}$ tests - about $99.3 \% \mathrm{CO}_{2}$ and $0.3 \% \mathrm{H}_{2}$. Both $\mathrm{N}_{2}$ and $\mathrm{O}_{2}$ are consumed in the KC-1 P500 and M500 tests. A fraction of the $\mathrm{N}_{2}$ returned to the gas phase during the period covered by the second sampling for both tests. Again, the $\mathrm{N}_{2}$ production in the second interval may have been caused by conversion of $\mathrm{UN}_{1.75}$ to $\mathrm{UO}_{2}$ by reaction with water or oxygen.

\footnotetext{
(a) As shown in Figure 3.2, rapid gas production occurred for each experiment after the first sampling. The surges are postulated to occur by the following mechanism during the gas sampling sequence. During gas sampling, the vessels first are cooled from $80^{\circ} \mathrm{C}$ to the $\sim 32^{\circ} \mathrm{C}$ hot cell temperature. Because the predominantly $\mathrm{CO}_{2}$ product gas has much higher solubility in water at lower temperature, it partially dissolves in the moist sludge. After the vessel has reached hot cell temperature, the vapor space is sampled and the vapor space back-filled with neon. The vessels then are closed and reheated to $80^{\circ} \mathrm{C}$. With heating, the $\mathrm{CO}_{2}$ dissolved during the cooling phase is driven from solution and the gas surge ensues.
} 
Table 4.4. Net and Cumulative Quantities of Gas Evolved for KC-1 P500 and $\mathrm{M} 500$ at $80^{\circ} \mathrm{C}$ and $95^{\circ} \mathrm{C}$

\begin{tabular}{|c|c|c|c|c|}
\hline \multirow[t]{3}{*}{ Gas } & \multicolumn{4}{|c|}{ Gas Quantities, moles, at Sampling Times } \\
\hline & \multicolumn{2}{|c|}{ KC-1 P500 } & \multicolumn{2}{|c|}{ KC-1 M500 } \\
\hline & $492.00 \mathrm{hr}$ & 969.34 hr & $487.66 \mathrm{hr}$ & $964.66 \mathrm{hr}$ \\
\hline \multirow{2}{*}{$\begin{array}{l}\mathrm{CO}_{2} \\
\text { Cumulative }\end{array}$} & $7.85 \mathrm{E}-05$ & $6.02 \mathrm{E}-05$ & $2.54 \mathrm{E}-04$ & $1.86 \mathrm{E}-04$ \\
\hline & $7.85 \mathrm{E}-05$ & $1.39 \mathrm{E}-04$ & $2.54 \mathrm{E}-04$ & 4.39E-04 \\
\hline \multirow{2}{*}{\begin{tabular}{l|}
$\mathrm{H}_{2}$ \\
Cumulative
\end{tabular}} & $3.60 \mathrm{E}-04$ & $8.36 \mathrm{E}-05$ & $4.91 \mathrm{E}-07$ & $7.56 \mathrm{E}-07$ \\
\hline & $3.60 \mathrm{E}-04$ & 4.44E-04 & $4.91 \mathrm{E}-07$ & $1.25 \mathrm{E}-06$ \\
\hline \multirow{2}{*}{$\begin{array}{l}\mathrm{N}_{2} \\
\text { Cumulative }\end{array}$} & $-5.05 \mathrm{E}-06$ & $6.51 \mathrm{E}-07$ & $-3.73 \mathrm{E}-06$ & $9.65 \mathrm{E}-07$ \\
\hline & $-5.05 \mathrm{E}-06$ & $-4.40 \mathrm{E}-06$ & $-3.73 \mathrm{E}-06$ & $-2.76 \mathrm{E}-06$ \\
\hline \multirow{2}{*}{\begin{tabular}{|l|}
$\mathrm{O}_{2}$ \\
Cumulative
\end{tabular}} & $-4.29 \mathrm{E}-06$ & $-4.55 \mathrm{E}-07$ & $-2.27 \mathrm{E}-06$ & $-1.03 \mathrm{E}-07$ \\
\hline & $-4.29 \mathrm{E}-06$ & $-4.74 \mathrm{E}-06$ & $-2.27 \mathrm{E}-06$ & $-2.37 \mathrm{E}-06$ \\
\hline \multirow{2}{*}{$\begin{array}{l}\mathrm{CH}_{4} \\
\text { Cumulative } \\
\end{array}$} & $1.28 \mathrm{E}-05$ & $\mathrm{E}-06$ & $1.02 \mathrm{E}-06$ & $6.24 \mathrm{E}-07$ \\
\hline & $1.28 \mathrm{E}-05$ & $1.56 \mathrm{E}-05$ & $1.02 \mathrm{E}$ & $1.64 \mathrm{E}-06$ \\
\hline \multirow{2}{*}{\begin{tabular}{|l|}
$\mathrm{C}_{2} \mathrm{H}_{\mathrm{x}}$ \\
Cumulative
\end{tabular}} & $1.42 \mathrm{E}-06$ & $4.55 \mathrm{E}-07$ & $1.18 \mathrm{E}-07$ & \\
\hline & $1.42 \mathrm{E}-06$ & 1.88 & 1.18 & $1.18 \mathrm{E}-07$ \\
\hline \multirow{2}{*}{$\begin{array}{l}\geq \mathrm{C}_{3} \mathrm{H}_{\mathrm{x}} \\
\text { Cumulative }\end{array}$} & 4.50E-07 & $1.76 \mathrm{E}-07$ & $3.38 \mathrm{E}-08$ & \\
\hline & $4.50 \mathrm{E}-07$ & $6.26 \mathrm{E}-07$ & $3.38 \mathrm{E}-08$ & $3.38 \mathrm{E}-08$ \\
\hline \multirow{2}{*}{\begin{tabular}{|l|}
$\sum \mathrm{C}_{\mathrm{y}} \mathrm{H}_{\mathrm{x}} \mathrm{C}$ \\
Cumulative
\end{tabular}} & $1.71 \mathrm{E}-05$ & 4.26 & $1.36 \mathrm{~F}$ & \\
\hline & 1.71 & 2.13 & $1.36 \mathrm{E}-06$ & $1.98 \mathrm{E}-06$ \\
\hline \multirow{2}{*}{$\begin{array}{l}{ }^{83} \mathrm{Kr} \\
\text { Cumulative }\end{array}$} & 4.32E-08 & 7.34E-09 & & $3.29 \mathrm{E}-10$ \\
\hline & 4.32E-08 & $5.06 \mathrm{E}-08$ & $0.00 \mathrm{E}+00$ & $3.29 \mathrm{E}-10$ \\
\hline \multirow{2}{*}{$\begin{array}{l}{ }^{84} \mathrm{Kr} \\
\text { Cumulative }\end{array}$} & $7.57 \mathrm{E}$ & $\mathrm{E}-08$ & $5.08 \mathrm{E}$ & $\mathrm{E}-10$ \\
\hline & 7.57E-08 & 8.74E-08 & $5.08 \mathrm{E}-09$ & $5.57 \mathrm{E}-09$ \\
\hline \multirow{2}{*}{$\begin{array}{l}{ }^{85} \mathrm{Kr} \\
\text { Cumulative }\end{array}$} & $1.08 \mathrm{E}-08$ & $1.47 \mathrm{E}-09$ & $3.38 \mathrm{E}-10$ & $4.93 \mathrm{E}-11$ \\
\hline & $1.08 \mathrm{E}-08$ & 1.23 & $3.38 \mathrm{~F}$ & $3.88 \mathrm{E}-10$ \\
\hline \multirow{2}{*}{$\begin{array}{l}{ }^{86} \mathrm{Kr} \\
\text { Cumulative }\end{array}$} & $1.26 \mathrm{E}-07$ & $1.47 \mathrm{E}-08$ & $1.02 \mathrm{E}-08$ & $9.86 \mathrm{E}-10$ \\
\hline & $1.26 \mathrm{E}-07$ & $1.41 \mathrm{E}-07$ & $1.02 \mathrm{E}-08$ & $1.11 \mathrm{E}-08$ \\
\hline \multirow{2}{*}{\begin{tabular}{|l|}
$\mathrm{Kr}$ \\
Cumulative
\end{tabular}} & $2.56 \mathrm{E}-07$ & $3.52 \mathrm{E}-08$ & $1.56 \mathrm{E}-08$ & $1.86 \mathrm{E}-09$ \\
\hline & $2.56 \mathrm{E}-07$ & $2.91 \mathrm{E}-07$ & $1.56 \mathrm{E}-08$ & $1.74 \mathrm{E}-08$ \\
\hline \multirow{2}{*}{$\begin{array}{l}{ }^{130} \mathrm{Xe} \\
\text { Cumulative }\end{array}$} & $5.40 \mathrm{E}-10$ & $5.87 \mathrm{E}-11$ & & \\
\hline & $5.40 \mathrm{E}-10$ & 5.991 & $0.00 \mathrm{E}$ & $0.00 \mathrm{E}+00$ \\
\hline \multirow{2}{*}{$\begin{array}{l}{ }^{131} \mathrm{Xe} \\
\text { Cumulative }\end{array}$} & $2.34 \mathrm{E}-07$ & $3.37 \mathrm{E}-08$ & $1.52 \mathrm{~F}$ & $3.29 \mathrm{E}-09$ \\
\hline & $2.34 \mathrm{E}-07$ & $2.68 \mathrm{E}-07$ & $1.52 \mathrm{E}-08$ & $1.85 \mathrm{E}-08$ \\
\hline \multirow{2}{*}{$\begin{array}{l}{ }^{132} \mathrm{Xe} \\
\text { Cumulative }\end{array}$} & $3.60 \mathrm{E}-07$ & $5.57 \mathrm{E}-08$ & $2.20 \mathrm{E}-08$ & 4.93E-09 \\
\hline & $3.60 \mathrm{E}-07$ & $4.16 \mathrm{E}-07$ & $2.20 \mathrm{E}-08$ & 2.69E-08 \\
\hline \multirow{2}{*}{$\begin{array}{l}{ }^{134} \mathrm{Xe} \\
\text { Cumulative }\end{array}$} & $5.94 \mathrm{E}-07$ & $9.39 \mathrm{E}-08$ & $3.38 \mathrm{E}-08$ & $6.57 \mathrm{E}-09$ \\
\hline & $5.94 \mathrm{E}-07$ & $6.88 \mathrm{E}-07$ & $3.38 \mathrm{E}-08$ & 4.04E-08 \\
\hline \multirow{2}{*}{$\begin{array}{l}{ }^{136} \mathrm{Xe} \\
\text { Cumulative }\end{array}$} & $8.83 \mathrm{E}-07$ & $1.39 \mathrm{E}-07$ & 4.91E-08 & $9.86 \mathrm{E}-09$ \\
\hline & 8.83E-07 & $1.02 \mathrm{E}-06$ & $4.91 \mathrm{E}-08$ & 5.89E-08 \\
\hline \multirow{2}{*}{\begin{tabular}{|l|}
$\sum \mathrm{Xe}$ \\
Cumulative
\end{tabular}} & $2.07 \mathrm{E}-06$ & $3.23 \mathrm{E}-07$ & $1.20 \mathrm{E}-07$ & $2.46 \mathrm{E}-08$ \\
\hline & $2.07 \mathrm{E}-06$ & $2.39 \mathrm{E}-06$ & $1.20 \mathrm{E}-07$ & $1.45 \mathrm{E}-07$ \\
\hline
\end{tabular}


The high fraction of $\mathrm{H}_{2}$ in the gas product and higher specific gas production for the $\mathrm{KC}-1 \mathrm{P} 500$ sludge as compared with the $\mathrm{KC}-1 \mathrm{M} 500$ sludge is reflected in the estimated uranium metal concentrations for the two materials. As shown in Table 4.5, the uranium metal concentration in the $\mathrm{KC}-1 \mathrm{P} 500$ sludge is $0.39 \mathrm{wt} \%$, about 60 times higher than found in the KC-1 M500 sludge $(0.0066 \mathrm{wt} \%)$. The $\mathrm{KC}-1 \mathrm{Un}$ and $\mathrm{KC}-1 \mathrm{Mix}$ tests, derived from the same $\mathrm{KC}-1$ sludge, are 0.0120 and $0.00877 \mathrm{wt} \%$ uranium metal, respectively, based on the chemical $\left(\mathrm{H}_{2}, \mathrm{O}_{2}, \mathrm{~N}_{2}\right)$ data given in Table 4.2. Because the KC-1 P500 fraction represents about $12 \mathrm{wt} \%$ of the total $\mathrm{KC}-1$ sludge and the M500 fraction about $88 \mathrm{wt} \%$, the estimated uranium metal content in the combined size fractions is $0.051 \mathrm{wt} \%[(0.12 \times 0.390 \%)+(0.88 \times 0.00657 \%)]$, about five times higher than that observed for the KC-1 Un and KC-1 Mix tests.

The higher estimated total uranium metal concentration found by combining the results from the P500 and M500 portions of KC-1 sludge compared with the results found in the KC-1 Un and KC-1 Mix tests is unexpected. It is surmised that in the case of the $\mathrm{KC}-1$ P500 test, enough uranium metal existed to produce a sufficiently high nascent hydrogen concentration to initiate the uranium hydride-mediated corrosion through Reactions 4 and 5 (see Section 4.1.1). In contrast, the other three tests (KC-1 Un, $\mathrm{KC}-1$ Mix, and KC-1 M500) may not have generated sufficiently high hydrogen concentrations or pressures to form the active $\mathrm{UH}_{3}$ intermediate or to dislodge the protective $\mathrm{UO}_{2}$ coating on the uranium metal particles. In the tests having low hydrogen concentrations, the corrosion reaction of uranium with water by Reaction 1 would have remained at a low rate and not progressed to the rapid hydride-mediated mechanism described by Reactions 4 and 5 .

Table 4.5. Reacted Metallic Uranium Calculated from Gas Generation and Consumption Reactions in KC-1 P500 and M500 Tests

\begin{tabular}{|c|c|c|c|}
\hline \multirow{2}{*}{ Reaction } & \multicolumn{3}{|c|}{ U Reacted Based on Various Reactions, moles } \\
\cline { 2 - 4 } & KC-1 P500 & KC-1 M500 & KC-1 Blend \\
\hline $\begin{array}{c}\text { Settled Sludge } \\
\text { Mass in Test, g }\end{array}$ & 14.15 & 22.30 & -- \\
\hline $\begin{array}{c}\text { Reaction 1 } \\
\mathrm{U}+2 \mathrm{H}_{2} \mathrm{O} \rightarrow \mathrm{UO}_{2}+2 \mathrm{H}_{2}\end{array}$ & $2.22 \mathrm{E}-4$ & $6.23 \mathrm{E}-7$ & -- \\
\hline $\begin{array}{c}\text { Reaction 2 } \\
\mathrm{U}+\mathrm{O}_{2} \rightarrow \mathrm{UO}_{2}\end{array}$ & $4.74 \mathrm{E}-6$ & $2.37 \mathrm{E}-6$ & -- \\
\hline $\begin{array}{c}\text { Reaction 3 } \\
\mathrm{U}+0.875 \mathrm{~N}_{2} \rightarrow \mathrm{UN} \mathrm{N}_{1.75}\end{array}$ & $5.03 \mathrm{E}-6$ & $3.16 \mathrm{E}-6$ & -- \\
\hline $\begin{array}{c}\text { Total Moles U } \\
\left(\begin{array}{r}\text { Reactions 1-3) }\end{array}\right.\end{array}$ & $2.32 \mathrm{E}-4$ & $6.15 \mathrm{E}-6$ & -- \\
\hline $\begin{array}{c}\mathrm{U} \text { metal, wt\% } \\
\text { settled sludge, } \\
\text { Reactions 1-3 }\end{array}$ & 0.39 & 0.00657 & 0.0514 \\
\hline $\begin{array}{c}\text { Settled Sludge } \\
\text { Mass in Test, g }\end{array}$ & 14.15 & 22.30 & -- \\
\hline $\begin{array}{c}\mathrm{U} \text { metal, wt\% } \\
\text { settled sludge, Kr }\end{array}$ & 3.69 & 0.140 & 0.556 \\
\hline $\begin{array}{c}\mathrm{U} \text { metal, wt\% } \\
\text { settled sludge, Xe }\end{array}$ & 3.77 & 0.145 & 0.569 \\
\hline
\end{tabular}

(a) Weighted combination of KC-1 P500 and KC-1 M500 results: $0.12 \times(\mathrm{KC}-1 \mathrm{P} 500$ value $)+0.88 \times(\mathrm{KC}-1 \mathrm{M} 500$ value $)$. 
A similar situation may be occurring in the Series I KC-2/3 P250 large-scale ( $\sim 800$-ml vessel volume) test run at $\sim 32^{\circ} \mathrm{C}$ (Delegard et al. 2000, Section 4.4). That test was projected to have a 145 -day induction time based on similar tests conducted in the small-scale $(\sim 30 \mathrm{ml})$ vessels. However, the KC-2/3 P250 large-scale test still has not overcome its induction time, even after $\sim 420$ days. In the Series I report it was stated that the longer induction time in the $32^{\circ} \mathrm{C}$ large-scale test is likely caused by the larger vapor/sludge volume ratio $(\sim 10)$ compared with the small-scale tests $(\sim 1)$. The $\mathrm{H}_{2}$ concentration in the large-scale test would be more dilute and thus not sufficient to initiate the hydride-mediated corrosion. According to Wilkinson (1962, p. 838):

In aqueous corrosion, no uranium hydride will appear at any temperature below the boiling point unless hydrogen gas is trapped so as to build up the pressure in equilibrium with dissolved hydrogen in the water. The lower the temperature, the higher is the pressure of hydrogen that will be required to provide the activity necessary to form a hydride.

About $96 \%$ of the uranium metal corrosion in the $\mathrm{KC}-1 \mathrm{P} 500$ test is from the reaction with water, judging from the $\mathrm{H}_{2}$ quantity evolved; about $10 \%$ of the uranium corrosion in the $\mathrm{KC}-1 \mathrm{M} 500$ test is due to reaction with water. The reactions of uranium metal with $\mathrm{O}_{2}$ and $\mathrm{N}_{2}$ also are greater in the uranium-rich $\mathrm{KC}-1 \mathrm{P} 500$ test than in the KC-1 M500 test. The higher uranium metal concentration in the larger sizefraction sludge in these tests with KC-1 P500 $(>500 \mu \mathrm{m})$ and KC-1 M500 $(<500 \mu \mathrm{m})$ sludges also was observed in the Series I tests for the KC-2/3, KC-4, and KC-5 sludges segregated at the $250-\mu \mathrm{m}$ threshold. The classification of uranium metal to larger size fractions was attributed to adherence of the uranium oxide product to the underlying uranium metal and to the formation of oxide/metal particles from larger metal particles arising from fuel fragmentation by moist thermal treatment of fuel. A similar phenomenon also may be operant in the KC-1 P500 and M500 tests.

As seen in Table 4.5, the concentrations of uranium metal predicted based on $\mathrm{Kr}$ and $\mathrm{Xe}$ release agree well with each other for the KC-1 P500 and M500 fractions and with results for the combined total KC-1 sludge. However, the uranium concentrations predicted by the $\mathrm{Kr}$ and Xe release for KC-1 P500 (3.7 wt\%), M500 (0.14 wt\%), and the combined $\mathrm{KC}-1$ (0.57 wt\%) sludge are about 10, 20, and 10 times higher, respectively, than predicted based on the corrosion reactions 1-3. Again, the most plausible explanation of the lower uranium concentration predicted based on the corrosion reactions is that uranium-rich sludge solids consume a substantial fraction of the hydrogen product. The uranium concentration calculated for the total KC-1 (weighted KC-1 P500 and M500) is $0.57 \mathrm{wt} \%$, which agrees with the $0.56 \mathrm{wt} \%$ estimated from the $\mathrm{KC}-1$ Mix test data, based in both cases on fission product gas release data.

Estimates of uranium metal concentration from both corrosion gas and fission product gas release show that very little metallic uranium is present in canister sludge made up of particles less than $500 \mu \mathrm{m}$. During Series I, sludge was fractionated at $250 \mu \mathrm{m}$, so questions remained about the uranium metal content in particles in the $250-\mu \mathrm{m}$ to $500-\mu \mathrm{m}$ range. Furthermore, since the $\mathrm{KC}-1$ sample was stored at about $32^{\circ} \mathrm{C}$ for 14 months, the uranium metal particles in the P500 fraction were probably initially present at a size significantly larger than $500 \mu \mathrm{m}$. Using the rate equation for uranium metal with oxygen free water given in the Spent Nuclear Fuel Project Technical Data Book, Volume 1 (Reilly 1998; Equation 6 in Section 4.1.1 of this report), it is estimated that a spherical uranium metal particle $975 \mu \mathrm{m}$ in diameter would corrode to about $500 \mu \mathrm{m}$ after 14 months at $32^{\circ} \mathrm{C}$. When considering the $91 / 2$-month difference in storage times between the canister sludge used in Series I (KC-2/3) and the canister sludge used in Series II (KC-1), the estimated uranium metal contents are comparable. Canister sludge sample KC-2/3, which 
contained $\sim 1.9 \mathrm{wt} \%$ uranium metal, was reasonably well modeled by assuming an initial particle size of $800 \mu \mathrm{m}$ (range was 680 to $970 \mu \mathrm{m}$ ) (Delegard et al. 2000). Using Equation 6, in $9 \frac{1}{2} 2$ months at $32^{\circ} \mathrm{C}$, about $75 \mathrm{wt} \%$ of an $800-\mu \mathrm{m}$ uranium metal particle will corrode. That is, sludge initially containing $\sim 1.9 \mathrm{wt} \%$ uranium metal is projected to contain $\sim 0.48 \mathrm{wt} \%$ uranium metal after the $91 / 2$ months at $32^{\circ} \mathrm{C}-$ which is close to the $0.56 \mathrm{wt} \%$ estimated for $\mathrm{KC}-1$.

A similar extrapolation was performed to estimate the uranium metal content of KC-1 P500 at the beginning of the $91 / 2$-month storage period (Appendix B). The results from this extrapolation predict that KC-1 P500 contained about $13 \mathrm{wt} \%$ uranium metal when placed on the same time basis as KC-2/3 P250, which was shown to contain $7.4 \mathrm{wt} \%$ uranium metal. The higher predicted uranium metal for KC-1 P500 may partially be attributed to the fact that the uranium metal was concentrated in a smaller sample mass for $\mathrm{KC}-1$. The $\mathrm{P} 500$ fraction of $\mathrm{KC}-1$ comprised about $12 \%$ of the $\mathrm{KC}-1$ (whole) sample (Section 2.2.1), while the P250 fraction comprised about 22\% of KC-2/3 (whole) (Delegard et al. 2000).

Isotope ratios observed for the $\mathrm{Kr}$ and $\mathrm{Xe}$ fission product gases are compared with ORIGEN code predictions in Table 4.6. The ${ }^{83} \mathrm{Kr}$ concentration is low in the KC-1 M500 test (at least partially due to a lower-than-detection limit value in the first gas sampling; see Table 4.4), but other isotope concentrations and the final $\mathrm{Xe}: \mathrm{Kr}$ mole ratios all are consistent with expectations from the ORIGEN code. The ${ }^{85} \mathrm{Kr}$ concentrations in the P500 and M500 tests imply times since discharge of 7.5 and 18 years, respectively. The value for P500 is not credible given the 14-plus years between the last irradiation in N Reactor and when these tests were conducted. The 7.5- and 18-year times compare with 17 and 30 years since discharge predicted from the KC-1 Un and KC-1 Mix sludge tests derived from the same source sludge.

The hydrocarbon gases (primarily methane) generated in the KC-1 P500 and M500 tests represent 18 ppm and $1.1 \mathrm{ppm}$ carbon in the sludge, respectively, and are similar to the 0.30 and $6.9 \mathrm{ppm}$ carbon found in the KC-1 Un and KC-1 Mix tests. The carbide concentrations in the uranium metal (based on $\mathrm{Kr}$ and Xe determinations of uranium metal concentrations) are about 480 and $750 \mathrm{ppmp} \mathrm{U}$, respectively, for the KC-1 P500 and M500 tests. These values are similar to those observed in the KC-1 Un and KC-1 Mix tests and also agree with the expected $550 \pm 185$ ppmp value. About $73 \%$ and $83 \%$ of the hydrocarbon

Table 4.6. Isotope Ratios for KC-1 P500 and M500 Tests

\begin{tabular}{|c|c|c|c|}
\hline \multirow{2}{*}{ Gas } & \multicolumn{2}{|c|}{ Isotopic Composition, atom\% } & \multirow{2}{*}{ ORIGEN } \\
\cline { 2 - 3 } & KC-1 P500 & KC-1 M500 & \\
\hline${ }^{83} \mathrm{Kr}$ & 17.4 & 1.9 & 13.3 \\
\hline${ }^{84} \mathrm{Kr}$ & 30.0 & 32.0 & 28.3 \\
\hline${ }^{85} \mathrm{Kr}$ & 4.2 & 2.2 & 6.8 \\
\hline${ }^{86} \mathrm{Kr}$ & 48.4 & 63.9 & 51.5 \\
\hline${ }^{130} \mathrm{Xe}$ & 0.0 & 0.0 & 0.05 \\
\hline${ }^{131} \mathrm{Xe}$ & 11.2 & 12.8 & 10.7 \\
\hline${ }^{132} \mathrm{Xe}$ & 17.4 & 18.6 & 18.0 \\
\hline${ }^{134} \mathrm{Xe}$ & 28.7 & 27.9 & 28.0 \\
\hline${ }^{136} \mathrm{Xe}$ & 42.7 & 40.7 & 43.2 \\
\hline $\mathrm{Xe}: \mathrm{Kr}$ & 8.2 & 8.3 & 8.2 \\
\hline
\end{tabular}

(a) ORIGEN2 calculation for N Reactor MkIV fuel at $2921 \mathrm{MWD} / \mathrm{TeU}$; ratios change $<3 \%$ relative at lower burnups; ${ }^{85} \mathrm{Kr}$ has a 10.76 -year half-life. 
carbon in the KC-1 P500 and M500 tests, respectively, are from methane. These percentages are similar to those found in the tests with $\mathrm{KC}-1 \mathrm{Un}$ and $\mathrm{KC}-1$ Mix sludge and with the $59 \%$ to $73 \%$ observed in the Series I tests with KC-2/3 P250 sludge.

The $\mathrm{CO}_{2}$ evolved from the KC-1 P500 and M500 tests gives qualitative evidence of the reaction of schoepite with calcite to form becquerelite but, again, little $\mathrm{pH}$ change was observed after reaction. The $\mathrm{CO}_{2}$ quantities correspond to a lower limit of inorganic carbon concentration in the settled sludge of 51 and $100 \mathrm{ppm}$, respectively. These values are similar to those found in the KC-1 Un and KC-1 Mix tests. The total carbon reporting to the gas phase as hydrocarbon and $\mathrm{CO}_{2}$ gases in the $\mathrm{KC}-1$ tests is about 111 , 80, 69, and $101 \mathrm{ppm}$ for KC-1 Un, KC-1 Mix, KC-1 P500, and KC-1 M500, respectively. No chemical analyses of the $\mathrm{KC}-1$ sludge for organic or inorganic carbon concentrations were performed, however.

\subsection{Gas Analysis for FE-1, FE-3, FE-5 and FE-4/6 Single-Pull Sludges at $90^{\circ} \mathrm{C}$ and $95^{\circ} \mathrm{C}$}

Samples from FE-1, FE-3, FE-5, and FE-4/6 single-pull KE Basin sludges were run at $90^{\circ} \mathrm{C}$ for about 490 hours and then at $95^{\circ} \mathrm{C}$ for a further 477 hours. The FE-3 and FE-5 sludges each produced about 0.005 moles total gas per kg sludge and seemed to have reached exhaustion in gas production, judging by the flatness of the gas production rate beyond about 800 hours. The FE- 1 and FE-4/6 sludges each produced about 0.015 moles of gas per $\mathrm{kg}$ sludge, but did not appear to be at completion at the end of nearly 1000 hours of heating (Figure 3.3). The gas generation rates for all tests were relatively constant over the first 800 hours of reaction and did not increase significantly when the temperature rose from $90^{\circ} \mathrm{C}$ to $95^{\circ} \mathrm{C}$. The maximum rates were about $5.4 \times 10^{-4}$ moles $/ \mathrm{kg}$-day for the $\mathrm{FE}-1$ and FE- $4 / 6$ sludges and about $1.8 \times 10^{-4}$ moles/kg-day for the FE-3 and FE-5 sludges.

The quantities of gas generated and consumed in each test are listed in Table 4.7. Carbon dioxide is the predominant gas product in each test and comprises $96.7 \%, 99.4 \%, 98.7 \%$, and $99.1 \%$ of the FE-1, FE-3, FE-5, and FE-4/6 gas, respectively. Hydrogen constitutes most of the remaining gas at $3.0 \%, 0.33 \%$, $1.1 \%$, and $0.73 \%$ of the respective products. The balance is hydrocarbon (e.g., methane, ethane) and Xe fission product gases. Note, however, that no $\mathrm{Kr}$ was detectable in any test, and Xe was also below detection in the test with FE-3 sludge. Both oxygen and nitrogen were consumed in all tests. Similar to the tests with $\mathrm{KC}-1$ sludge, in which $\mathrm{N}_{2}$ was evolved in the period of the second sampling in all four cases (see Sections 4.2 and 4.3), $\mathrm{N}_{2}$ evolution was observed in the second sampling in each of the single-pull tests. The conversion of $\mathrm{UN}_{1.75}$ to $\mathrm{UO}_{2}$ by reaction with water or oxygen may be the cause of the $\mathrm{N}_{2}$ production in the second interval.

Estimated quantities of uranium metal corroded, based on evidence of reaction with water, $\mathrm{O}_{2}$, and $\mathrm{N}_{2}$, are given in Table 4.8. The total uranium metal concentrations in the FE single-pull sludges are remarkably consistent ( 0.013 to $0.017 \mathrm{wt} \%$ ) and are slightly higher than the $\sim 0.01 \%$ uranium metal concentrations found in the same manner for the $\mathrm{KC}-1 \mathrm{Un}$ and $\mathrm{KC}-1$ Mix sludge tests. The contributions of Reactions 1-3 to uranium metal corrosion vary from test to test, however. For the FE-1 sludge, Reactions 1 and 3 provide about $40 \%$ each and Reaction 2 provides $20 \%$ of the corrosion. Reactions 2 and 3 provide nearly all the corrosion in the FE-3 and FE-5 tests; nearly $80 \%$ is by $\mathrm{O}_{2}$ alone in the FE-5. Uranium in the FE-4/6 test was corroded $14 \%$ by Reaction 1, 55\% by Reaction 2, and 31\% by Reaction 3 .

The $\mathrm{Kr}$ isotope concentrations were below detection limits and $\mathrm{Xe}$ concentrations were near or below detection limits for all the single-pull tests. However, unlike the tests with the KC-1 sludge, the uranium 
Table 4.7. Net and Cumulative Quantities of Gas Evolved for FE-1, FE-3, FE-5, and FE-4/6 at $90^{\circ} \mathrm{C}$ and $95^{\circ} \mathrm{C}$

\begin{tabular}{|c|c|c|c|c|c|c|c|c|}
\hline \multirow[t]{3}{*}{ Gas } & \multicolumn{8}{|c|}{ Gas Quantities, moles, at Sampling Times } \\
\hline & \multicolumn{2}{|c|}{ FE-1 } & \multicolumn{2}{|c|}{ FE-3 } & \multicolumn{2}{|c|}{ FE-5 } & \multicolumn{2}{|c|}{ FE-4/6 } \\
\hline & & \multicolumn{2}{|c|}{$493.00 \mathrm{hr} 970.00 \mathrm{hr}$} & \multicolumn{4}{|c|}{\begin{tabular}{|l|l|l|}
$493.33 \mathrm{hr}$ & $969.67 \mathrm{hr} 486.33 \mathrm{hr}$ & $963.00 \mathrm{hr}$ \\
\end{tabular}} \\
\hline $\mathrm{CO}_{2}$ & $2.35 \mathrm{E}-04$ & $2.34 \mathrm{E}-04$ & $8.52 \mathrm{E}-05$ & $8.31 \mathrm{E}-05$ & $7.71 \mathrm{E}-05$ & $8.02 \mathrm{E}-05$ & $1.87 \mathrm{E}-04$ & $1.65 \mathrm{E}-04$ \\
\hline Cumulative & $2.35 \mathrm{E}-04$ & 4.69E-04 & $8.52 \mathrm{E}-05$ & $1.68 \mathrm{E}-04$ & $7.71 \mathrm{E}-05$ & $1.57 \mathrm{E}-04$ & $1.87 \mathrm{E}-04$ & $3.53 \mathrm{E}-04$ \\
\hline $\mathrm{H}_{2}$ & $1.33 \mathrm{E}-05$ & $1.48 \mathrm{E}-06$ & $2.53 \mathrm{E}-07$ & $3.06 \mathrm{E}-07$ & $7.32 \mathrm{E}-07$ & $9.82 \mathrm{E}-07$ & $1.22 \mathrm{E}-06$ & $1.38 \mathrm{E}-06$ \\
\hline Cumulative & $1.33 \mathrm{E}-05$ & $1.47 \mathrm{E}-05$ & $2.53 \mathrm{E}-07$ & 5.58E-07 & $7.32 \mathrm{E}-07$ & $1.71 \mathrm{E}-06$ & $1.22 \mathrm{E}-06$ & $2.60 \mathrm{E}-06$ \\
\hline $\mathrm{N}_{2}$ & $-5.77 \mathrm{E}-06$ & 3.09E-07. & $-7.11 \mathrm{E}-06$ & $1.19 \mathrm{E}-06$ & $-2.13 \mathrm{E}-06$ & $1.89 \mathrm{E}-07$ & $-2.80 \mathrm{E}-06$ & $3.63 \mathrm{E}-07$ \\
\hline Cumulative & $-5.77 \mathrm{E}-06$ & $-5.46 \mathrm{E}-06$ & $-7.11 \mathrm{E}-06$ & $-5.92 \mathrm{E}-06$ & $-2.13 \mathrm{E}-06$ & $-1.94 \mathrm{E}-06$ & $-2.80 \mathrm{E}-06$ & $-2.44 \mathrm{E}-06$ \\
\hline $\mathrm{O}_{2}$ & $-3.10 \mathrm{E}-06$ & $-4.05 \mathrm{E}-07$ & $-4.03 \mathrm{E}-06$ & -7.8 & $-9.46 \mathrm{E}-06$ & $-1.52 \mathrm{E}-06$ & $-4.05 \mathrm{E}-06$ & E-07 \\
\hline Cumulative & $-3.10 \mathrm{E}-06$ & $-3.51 \mathrm{E}-06$ & $-4.03 \mathrm{E}-06$ & $-4.81 \mathrm{E}-06$ & $-9.46 \mathrm{E}-06$ & $-1.10 \mathrm{E}-05$ & $-4.05 \mathrm{E}-06$ & $-5.00 \mathrm{E}-06$ \\
\hline $\mathrm{CH}_{4}$ & $1.05 \mathrm{E}-07$ & 3.44E-08 & 5.42E-08 & 5.39E-08 & $6.51 \mathrm{E}-08$ & $8.18 \mathrm{E}-08$ & $8.14 \mathrm{E}-08$ & $\overline{E-08}$ \\
\hline Cumulative & $1.05 \mathrm{E}-07$ & \begin{tabular}{|c|}
$1.39 \mathrm{E}-07$ \\
\end{tabular} & $5.42 \mathrm{E}-08$ & $1.08 \mathrm{E}-07$ & $6.51 \mathrm{E}-08$ & $1.47 \mathrm{E}-07$ & $8.14 \mathrm{E}-08$ & E-07 \\
\hline $\mathrm{C}_{2} \mathrm{H}_{\mathrm{x}}$ & $3.31 \mathrm{E}-07$ & 3.78E-07 & $1.08 \mathrm{E}-07$ & 8.99E-08 & $4.88 \mathrm{E}-08$ & 4.91E-08 & $1.14 \mathrm{E}-07$ & $9.73 \mathrm{E}-08$ \\
\hline Cumulative & $3.31 \mathrm{E}-07$ & 7.10E-07 & $1.08 \mathrm{E}-07$ & $1.98 \mathrm{E}-07$ & $4.88 \mathrm{E}-08$ & 9.79E-08 & $1.14 \mathrm{E}-07$ & $2.11 \mathrm{E}-07$ \\
\hline$\geq \mathrm{C}_{3} \mathrm{H}_{\mathrm{x}}$ & $1.05 \mathrm{E}-07$ & $6.88 \mathrm{E}-08$ & 9.03E-08 & 8.99 & $1.63 \mathrm{E}-08$ & $4.91 \mathrm{E}-08$ & $8.14 \mathrm{E}-08$ & -08 \\
\hline Cumulative & $1.05 \mathrm{E}-07$ & 1.73E-07 & 9.03E-08 & 1.80 & $3 \mathrm{E}-08$ & $6.54 \mathrm{E}-08$ & $8.14 \mathrm{E}-08$ & $8-07$ \\
\hline$\sum \mathrm{C}_{\mathrm{y}} \mathrm{H}_{\mathrm{x}} \mathrm{C}$ & $1.10 \mathrm{E}-06$ & 1.01E-06 & $5.57 \mathrm{E}-07$ & $5.19 \mathrm{E}-07$ & $2.14 \mathrm{E}-07$ & $3.36 \mathrm{E}-07$ & 5.68E-07 & $4.65 \mathrm{E}-07$ \\
\hline Cumul & $1.10 \mathrm{E}-06$ & $2.11 \mathrm{E}-06$ & $5.57 \mathrm{E}-07$ & 1.08 & $2.14 \mathrm{E}-07$ & $5.50 \mathrm{E}-07$ & 5.68E-07 & $\mathrm{E}-06$ \\
\hline${ }^{83} \mathrm{Kr}$ & & & & & & & & \\
\hline Cumula & $0.00 \mathrm{E}+00$ & $0.00 \mathrm{E}+00$ & $0.00 \mathrm{E}+00$ & $0.00 \mathrm{~F}$ & $0.00 \mathrm{E}+00$ & $0.00 \mathrm{E}+00$ & $0.00 \mathrm{E}+00$ & $\mathrm{E}+00$ \\
\hline${ }^{84} \mathrm{Kr}$ & & & & & & & & \\
\hline Cumu & $0.00 \mathrm{E}+00$ & $0.00 \mathrm{E}+00$ & $0.00 \mathrm{E}+00$ & $0.00 \mathrm{E}+00$ & $0.00 \mathrm{E}+00$ & $0.00 \mathrm{E}+00$ & $0.00 \mathrm{E}+00$ & $0.00 \mathrm{E}+00$ \\
\hline${ }^{85} \mathrm{Kr}$ & & & & & & & & \\
\hline Cumulative & $0.00 \mathrm{E}+00$ & $0.00 \mathrm{E}+00$ & $0.00 \mathrm{E}+00$ & $0.00 \mathrm{E}+00$ & $0.00 \mathrm{E}+00$ & $0.00 \mathrm{~L} / 00$ & & $0.00 \mathrm{E}+0 \mathrm{C}$ \\
\hline${ }^{86} \mathrm{Kr}$ & & & & & & & & \\
\hline Cumul & $0.00 \mathrm{E}+00$ & $0.00 \mathrm{E}+00$ & $0.00 \mathrm{E}+00$ & 0.00 & $0.00 \mathrm{E}+00$ & $\mathrm{E}+00$ & +00 & $0.00 \mathrm{E}+00$ \\
\hline$\sum \mathrm{Kr}$ & 0.00 & 0.0 & +00 & 0.00 & $\mathrm{E}+00$ & 0.0 & +00 & $E+00$ \\
\hline Cumul & $0.00 \mathrm{E}+00$ & $0.00 \mathrm{E}+00$ & $0.00 \mathrm{E}+00$ & $0.00 \mathrm{E}+00$ & $0.00 \mathrm{E}+00$ & 0.00 & $0.00 \mathrm{E}+00$ & +00 \\
\hline${ }^{130} \mathrm{Xe}$ & $3.49 \mathrm{E}-10$ & & & & & & $9.77 \mathrm{E}-10$ & \\
\hline Cumulative & $3.49 \mathrm{E}-10$ & $3.49 \mathrm{E}-10$ & $0.00 \mathrm{E}+00$ & $0.00 \mathrm{E}+00$ & $0.00 \mathrm{E}+00$ & $0.00 \mathrm{E}+00$ & $9.77 \mathrm{E}-10$ & $9.77 \mathrm{E}-10$ \\
\hline${ }^{131} \mathrm{Xe}$ & $2.27 \mathrm{E}-09$ & $3.44 \mathrm{E}-10$ & & & $1.63 \mathrm{E}-09$ & $9.82 \mathrm{E}-10$ & $4.89 \mathrm{E}-10$ & \\
\hline Cumul & $2.27 \mathrm{E}-09$ & 2.61E-09 & $0.00 \mathrm{E}+00$ & $0.00 \mathrm{E}+00$ & $1.63 \mathrm{E}-09$ & $2.61 \mathrm{E}-09$ & $4.89 \mathrm{E}-10$ & E-10 \\
\hline${ }^{132} \mathrm{Xe}$ & $3.49 \mathrm{E}-09$ & $5.16 \mathrm{E}-10$ & & & $3.25 \mathrm{E}-09$ & $1.47 \mathrm{E}-09$ & $1.14 \mathrm{E}-09$ & \\
\hline Cumulative & $3.49 \mathrm{E}-09$ & 4.00E-09 & $0.00 \mathrm{E}+00$ & $0.00 \mathrm{E}+00$ & $3.25 \mathrm{E}-09$ & 4.73E-09 & $1.14 \mathrm{E}-09$ & $1.14 \mathrm{E}-09$ \\
\hline${ }^{134} \mathrm{Xe}$ & $8.72 \mathrm{E}-09$ & $6.88 \mathrm{E}-10$ & & & $4.88 \mathrm{E}-09$ & $1.64 \mathrm{E}-09$ & $6.52 \mathrm{E}-10$ & \\
\hline Cumulative & $8.72 \mathrm{E}-09$ & 9.41E-09 & $0.00 \mathrm{E}+00$ & $0.00 \mathrm{E}+00$ & $4.88 \mathrm{E}-09$ & $6.52 \mathrm{E}-09$ & $6.52 \mathrm{E}-10$ & $6.52 \mathrm{E}-10$ \\
\hline${ }^{136} \mathrm{Xe}$ & $8.72 \mathrm{E}-09$ & |1.03E-09 & & & $8.13 \mathrm{E}-09$ & $3.27 \mathrm{E}-09$ & $4.89 \mathrm{E}-10$ & \\
\hline Cumulative & $8.72 \mathrm{E}-09$ & 9.75E-09 & $0.00 \mathrm{E}+00$ & $0.00 \mathrm{E}+00$ & $8.13 \mathrm{E}-09$ & $1.14 \mathrm{E}-08$ & $4.89 \mathrm{E}-10$ & $4.89 \mathrm{E}-10$ \\
\hline$\sum \mathrm{Xe}$ & $2.35 \mathrm{E}-08$ & $2.58 \mathrm{E}-09$ & $0.00 \mathrm{E}+00$ & $0.00 \mathrm{E}+00$ & 1.79E-08 & 7.37E-09 & $3.75 \mathrm{E}-09$ & $0.00 \mathrm{E}+00$ \\
\hline Cumulative & $2.35 \mathrm{E}-08$ & $2.61 \mathrm{E}-08$ & $0.00 \mathrm{E}+00$ & $0.00 \mathrm{E}+00$ & $1.79 \mathrm{E}-08$ & $2.53 \mathrm{E}-08$ & $3.75 \mathrm{E}-09$ & $3.75 \mathrm{E}-09$ \\
\hline
\end{tabular}


Table 4.8. Reacted Metallic Uranium Calculated from Gas Generation and Consumption Reactions in FE-1, FE-3, FE-5, and FE-4/6 Tests

\begin{tabular}{|c|c|c|c|c|}
\hline \multirow[t]{2}{*}{ Reaction } & \multicolumn{4}{|c|}{ U Reacted Based on Various Reactions, moles } \\
\hline & FE-1 & FE-3 & FE-5 & FE-4/6 \\
\hline $\begin{array}{l}\text { Settled Sludge } \\
\text { Mass in Test, g } \\
\end{array}$ & 27.00 & 21.22 & 19.93 & 15.87 \\
\hline $\begin{array}{c}\text { Reaction 1 } \\
\mathrm{U}+2 \mathrm{H}_{2} \mathrm{O} \rightarrow \mathrm{UO}_{2}+2 \mathrm{H}_{2}\end{array}$ & 7.37E-6 & $2.79 \mathrm{E}-7$ & 8.57E-7 & $1.30 \mathrm{E}-6$ \\
\hline $\begin{array}{l}\text { Reaction 2 } \\
\mathrm{U}+\mathrm{O}_{2} \rightarrow \mathrm{UO}_{2}\end{array}$ & $3.51 \mathrm{E}-6$ & $4.81 \mathrm{E}-6$ & $1.10 \mathrm{E}-5$ & $5.00 \mathrm{E}-6$ \\
\hline $\begin{array}{c}\text { Reaction 3 } \\
\mathrm{U}+0.875 \mathrm{~N}_{2} \rightarrow \mathrm{UN}_{1.75}\end{array}$ & $6.24 \mathrm{E}-6$ & $6.77 \mathrm{E}-6$ & $2.22 \mathrm{E}-6$ & $2.79 \mathrm{E}-6$ \\
\hline $\begin{array}{c}\text { Total Moles U } \\
(\Sigma \text { Reactions 1-3) }\end{array}$ & $1.71 \mathrm{E}-5$ & $1.19 \mathrm{E}-5$ & $1.41 \mathrm{E}-5$ & $9.09 \mathrm{E}-6$ \\
\hline $\begin{array}{l}\text { U metal, wt } \% \\
\text { settled sludge, } \\
\text { Reactions } 1-3\end{array}$ & 0.0151 & 0.00133 & 0.0168 & 0.0136 \\
\hline $\begin{array}{c}\mathrm{U} \text { metal, wt } \% \\
\text { settled sludge, } \mathrm{Kr}\end{array}$ & -- & -- & -- & -- \\
\hline $\begin{array}{c}\text { U metal, wt } \% \\
\text { settled sludge, } \mathrm{Xe}\end{array}$ & 0.0215 & -- & 0.0272 & 0.00519 \\
\hline
\end{tabular}

metal concentrations found for the FE-1, FE-3, and FE-4/6 sludge tests, based on Xe fission product gas release, were comparable with the concentrations predicted based on Reactions 1-3.

Because of the low Xe gas concentrations, the Xe isotope percentages correspond poorly with those predicted by ORIGEN, except for the FE-5 results (Table 4.9).

The hydrocarbon concentrations found in FE-1, FE-3, FE-5, and FE-4/6 are 0.94, 0.61, 0.33, and $0.78 \mathrm{ppm}$, respectively. These concentrations are lower than found for all but one of the $\mathrm{KC}-1$ tests.

Table 4.9. Isotope Ratios for FE-1, FE-3, FE-5, and FE-4/6 Tests

\begin{tabular}{|c|c|c|c|c|c|}
\hline \multirow{2}{*}{ Gas } & \multicolumn{4}{|c|}{ Isotopic Composition, atom\% } & \multirow{2}{*}{ ORIGEN ${ }^{(\mathbf{a})}$} \\
\cline { 2 - 5 } & FE-1 & FE-3 & FE-5 & FE-4/6 & \\
\hline${ }^{83} \mathrm{Kr}$ & -- & -- & -- & -- & 13.3 \\
\hline${ }^{84} \mathrm{Kr}$ & -- & -- & -- & -- & 28.3 \\
\hline${ }^{85} \mathrm{Kr}$ & -- & -- & -- & -- & 6.8 \\
\hline${ }^{86} \mathrm{Kr}$ & -- & -- & -- & -- & 51.5 \\
\hline${ }^{130} \mathrm{Xe}$ & 1.3 & -- & -- & 26.1 & 0.05 \\
\hline${ }^{131} \mathrm{Xe}$ & 10.0 & -- & 10.3 & 13.0 & 10.7 \\
\hline${ }^{132} \mathrm{Xe}$ & 15.3 & -- & 18.7 & 30.4 & 18.0 \\
\hline${ }^{134} \mathrm{Xe}$ & 36.0 & -- & 25.8 & 17.4 & 28.0 \\
\hline${ }^{136} \mathrm{Xe}$ & 37.3 & -- & 45.2 & 13.0 & 43.2 \\
\hline $\mathrm{Xe}: \mathrm{Kr}$ & -- & -- & -- & -- & 8.2 \\
\hline
\end{tabular}

(a) ORIGEN2 calculation for N Reactor MkIV fuel at $2921 \mathrm{MWD} / \mathrm{TeU}$; ratios change $<3 \%$ relative at lower burnups; ${ }^{85} \mathrm{Kr}$ has a 10.76 -year half-life. 
Methane comprises $6.6 \%, 10 \%, 27 \%$, and $14 \%$ of the carbon in the evolved hydrocarbon as compared with $70 \%$ to $80 \%$ in the tests with $\mathrm{KC}-1$ sludge. Based on the uranium metal concentrations derived from the Xe results, carbide concentrations of 4400, 1200, and $15000 \mathrm{ppmp}$ in the uranium metal are projected for FE-1, FE-5, and FE-4/6, respectively. These anomalously high values, and the low fraction of methane, suggest that substantial contamination of noncarbide-origin hydrocarbon was present in the gas samples.

Carbon dioxide constitutes most of the gas product in the single-pull floor and pit sludge tests. The $\mathrm{CO}_{2}$ production found in the FE-1, FE-3, FE-5, and FE-4/6 tests correspond to 104-, 47-, 48-, and 125-ppm lower limits in inorganic carbon concentrations in the respective settled sludges. This range is similar to the 51- to 111-ppm values found for the $\mathrm{KC}-1$ sludge tests. However, the inorganic carbon concentrations found by chemical characterization of these sludges are much higher (1240, 1150, and 480 ppm for FE-3, FE-5, and the FE-4/6 composite, respectively; FE-1 was not analyzed for total inorganic carbon).

The low reactivity and gas generation rate from the single-pull sludge samples is consistent with the results from reaction calorimetry testing. Subsamples of FE-1, FE-3, FE-5, and FE-6 were evaluated for uranium metal content using an acid calorimetry technique at PNNL's Radiochemistry Processing Laboratory in September 2000 (Bredt et al. 2000). The results from this testing indicated that the samples contained little or no uranium metal. Additional calorimetry testing, using the reactive system screening tool (RSST), was performed on subsamples of FE-1, FE-3, FE-5, FE-6, and FE-7 at the 222-S Laboratory in June 2000 (Steen 2000). From the results of the RSST testing, it was concluded that all of these samples exhibited low thermochemical activity and low gas generation.

\subsection{Gas Analysis for $\mathrm{KC}-6$ and $96-06$ Sludges at $90^{\circ} \mathrm{C}$ and $95^{\circ} \mathrm{C}$}

A sample of KC-6 KE Basin sludge was heated at $90^{\circ} \mathrm{C}$ for 327 hours and then at $95^{\circ} \mathrm{C}$ for a further 642 hours. An archived sample of $\mathrm{KE}$ canister sludge, 96-06, began with 324 hours of heating at $80^{\circ} \mathrm{C}$ and was completed by 624 hours of heating at $95^{\circ} \mathrm{C}$. The $\mathrm{KC}-6$ sludge produced about 0.007 moles of gas per kilogram; the 96-06 sludge only produced about 0.002 moles of gas per kilogram. The KC-6 sludge still seemed to be producing gas after nearly 1000 hours of heating, whereas the 96-06 sludge evidently was at completion in its gas-generating reactions (Figure 3.4). Both tests inexplicably showed sharp downturns in gas generation for about 60 hours, just after the temperature increase to $95^{\circ} \mathrm{C}$. After these dips, the KC-6 sludge generated gas at a fairly constant rate through the end of the test, whereas the 96-06 sludge produced gas for about 150 hours and then was quiescent for the final 500 hours of the test. The maximum gas generation rates were about $5 \times 10^{-4}$ moles $/ \mathrm{kg}$-day for the $\mathrm{KC}-6$ sludge and $3 \times 10^{-4}$ moles/kg-day for the 96-06 sludge.

The quantities of gas generated and consumed in each test are listed in Table 4.10. Carbon dioxide again is the predominant gas product, comprising $91.4 \%$ of the KC-6 and $96.4 \%$ of the $96-06$ output. Hydrogen constitutes most of the remaining gas at $8.5 \%$ and $2.3 \%$, with hydrocarbon (e.g., methane, ethane) and fission product gases constituting the balance. However, both $\mathrm{Kr}$ and $\mathrm{Xe}$ were below detection in the KC- 6 test. Both oxygen and nitrogen were consumed in the KC-6 test and oxygen in the 96-06 test. Nitrogen was consumed in the period before the first sampling in both tests and evolved over the period of the second sampling. The amount of $\mathrm{N}_{2}$ produced in the second period for the 96-06 test was more than that reacted in the first period, however. 
Table 4.10. Net and Cumulative Quantities of Gas Evolved for KC-6 at $90^{\circ} \mathrm{C}$ and $95^{\circ} \mathrm{C}$ and $96-06$ at $80^{\circ} \mathrm{C}$ and $95^{\circ} \mathrm{C}$

\begin{tabular}{|c|c|c|c|c|}
\hline \multirow[t]{3}{*}{ Gas } & \multicolumn{4}{|c|}{ Gas Quantities, moles, at Sampling Times } \\
\hline & \multicolumn{2}{|c|}{ KC-6 } & \multicolumn{2}{|c|}{$96-06$} \\
\hline & $491.66 \mathrm{hr}$ & $968.33 \mathrm{hr}$ & $470.67 \mathrm{hr}$ & $947.33 \mathrm{hr}$ \\
\hline \multirow{2}{*}{$\begin{array}{l}\mathrm{CO}_{2} \\
\text { Cumulative }\end{array}$} & 9.60E-05 & 1.06E-04 & 6.03E-05 & $3.32 \mathrm{E}-05$ \\
\hline & $9.60 \mathrm{E}-05$ & $2.02 \mathrm{E}-04$ & $6.03 \mathrm{E}-05$ & $9.36 \mathrm{E}-05$ \\
\hline \multirow{2}{*}{\begin{tabular}{|l|}
$\mathrm{H}_{2}$ \\
Cumulative \\
\end{tabular}} & $1.03 \mathrm{E}-05$ & $8.54 \mathrm{E}-06$ & $1.59 \mathrm{E}-06$ & $6.15 \mathrm{E}-07$ \\
\hline & $1.03 \mathrm{E}-05$ & $1.89 \mathrm{E}-05$ & $1.59 \mathrm{E}-06$ & $2.21 \mathrm{E}-06$ \\
\hline \multirow{2}{*}{$\begin{array}{l}\mathrm{N}_{2} \\
\text { Cumulative }\end{array}$} & \begin{tabular}{|l|}
$-5.22 \mathrm{E}-06$ \\
\end{tabular} & $1.74 \mathrm{E}-06$ & $-2.55 \mathrm{E}-06$ & $7.53 \mathrm{E}-06$ \\
\hline & $-5.22 \mathrm{E}-06$ & $-3.49 \mathrm{E}-06$ & $-2.55 \mathrm{E}-06$ & $4.98 \mathrm{E}-06$ \\
\hline \multirow{2}{*}{\begin{tabular}{|l|}
$\mathrm{O}_{2}$ \\
Cumulative
\end{tabular}} & \begin{tabular}{|l|}
$-5.22 \mathrm{E}-06$ \\
\end{tabular} & $-1.82 \mathrm{E}-06$ & $-2.32 \mathrm{E}-06$ & $-4.93 \mathrm{E}-06$ \\
\hline & $-5.22 \mathrm{E}-06$ & $-7.04 \mathrm{E}-06$ & $-2.32 \mathrm{E}-06$ & $-7.25 \mathrm{E}-06$ \\
\hline \multirow{2}{*}{\begin{tabular}{|l|}
$\mathrm{CH}_{4}$ \\
Cumulative \\
\end{tabular}} & 3.62E-08 & 3.71E-08 & $8.38 \mathrm{E}-08$ & $4.55 \mathrm{E}-08$ \\
\hline & $3.62 \mathrm{E}-08$ & 7.33E-08 & 8.38E-08 & $1.29 \mathrm{E}-07$ \\
\hline \multirow{2}{*}{\begin{tabular}{|l|}
$\mathrm{C}_{2} \mathrm{H}_{\mathrm{x}}$ \\
Cumulative
\end{tabular}} & & & $8.38 \mathrm{E}-08$ & \\
\hline & $0.00 \mathrm{E}+00$ & $0.00 \mathrm{E}+00$ & 8.38E-08 & $8.38 \mathrm{E}-08$ \\
\hline \multirow{2}{*}{$\begin{array}{l}\geq \mathrm{C}_{3} \mathrm{H}_{\mathrm{x}} \\
\text { Cumulative }\end{array}$} & $1.81 \mathrm{E}-08$ & & $5.03 \mathrm{E}-08$ & $4.55 \mathrm{E}-08$ \\
\hline & $1.81 \mathrm{E}-08$ & $1.81 \mathrm{E}-08$ & $5.03 \mathrm{E}-08$ & $9.58 \mathrm{E}-08$ \\
\hline \multirow{2}{*}{\begin{tabular}{|l|}
$\sum \mathrm{C}_{\mathrm{y}} \mathrm{H}_{\mathrm{x}} \mathrm{C}$ \\
Cumulative
\end{tabular}} & & & $4.11 \mathrm{E}-07$ & \\
\hline & $9.36 \mathrm{E}-08$ & $1.31 \mathrm{E}-07$ & 4.11E-07 & $6.01 \mathrm{E}-07$ \\
\hline \multirow{2}{*}{$\begin{array}{l}{ }^{83} \mathrm{Kr} \\
\text { Cumulative }\end{array}$} & & & $1.51 \mathrm{E}-09$ & $1.37 \mathrm{E}-08$ \\
\hline & $0.00 \mathrm{E}+00$ & $0.00 \mathrm{E}+00$ & $1.51 \mathrm{E}-09$ & $1.52 \mathrm{E}-08$ \\
\hline \multirow{2}{*}{$\begin{array}{l}{ }^{48} \mathrm{Kr} \\
\text { Cumulative }\end{array}$} & & & $3.35 \mathrm{E}-09$ & $2.28 \mathrm{E}-08$ \\
\hline & $0.00 \mathrm{E}+00$ & $0.00 \mathrm{E}+00$ & $3.35 \mathrm{E}-09$ & $2.61 \mathrm{E}-08$ \\
\hline \multirow{2}{*}{$\begin{array}{l}{ }^{85} \mathrm{Kr} \\
\text { Cumulative }\end{array}$} & & & $1.68 \mathrm{E}-10$ & $2.28 \mathrm{E}-09$ \\
\hline & $0.00 \mathrm{E}+00$ & $0.00 \mathrm{E}+00$ & $1.68 \mathrm{E}-10$ & $2.44 \mathrm{E}-09$ \\
\hline \multirow{2}{*}{$\begin{array}{l}{ }^{86} \mathrm{Kr} \\
\text { Cumulative }\end{array}$} & & & $1.17 \mathrm{E}-08$ & $3.19 \mathrm{E}-08$ \\
\hline & $0.00 \mathrm{E}+00$ & $0.00 \mathrm{E}+00$ & $1.17 \mathrm{E}-08$ & $4.36 \mathrm{E}-08$ \\
\hline \multirow{2}{*}{\begin{tabular}{|l|}
$\Sigma \mathrm{Kr}$ \\
Cumulative
\end{tabular}} & $0.00 \mathrm{E}+00$ & $0.00 \mathrm{E}+00$ & $1.68 \mathrm{E}-08$ & 7.06E-08 \\
\hline & $0.00 \mathrm{E}+00$ & $0.00 \mathrm{E}+00$ & $1.68 \mathrm{E}-08$ & $8.73 \mathrm{E}-08$ \\
\hline \multicolumn{5}{|c|}{\begin{tabular}{|l|l|l|}
${ }^{130} \mathrm{Xe}$ & & \\
\end{tabular}} \\
\hline \multirow{2}{*}{$\begin{array}{l}\text { Cumulative } \\
{ }^{131} \mathrm{Xe}\end{array}$} & $0.00 \mathrm{E}+00$ & $0.00 \mathrm{E}+00$ & $0.00 \mathrm{E}+00$ & $0.00 \mathrm{E}+00$ \\
\hline & & & $1.68 \mathrm{E}-08$ & 7.97E-08 \\
\hline \multirow{2}{*}{\begin{tabular}{|l|} 
Cumulative \\
${ }^{132} \mathrm{Xe}$
\end{tabular}} & $0.00 \mathrm{E}+00$ & $0.00 \mathrm{E}+00$ & $1.68 \mathrm{E}-08$ & $9.64 \mathrm{E}-08$ \\
\hline & & & 2.35E-08 & $1.34 \mathrm{E}-07$ \\
\hline \multirow{2}{*}{\begin{tabular}{|l|} 
Cumulative \\
${ }^{134} \mathrm{Xe}$
\end{tabular}} & $0.00 \mathrm{E}+00$ & $0.00 \mathrm{E}+00$ & $2.35 \mathrm{E}-08$ & $1.58 \mathrm{E}-07$ \\
\hline & & & $3.35 \mathrm{E}-08$ & $2.09 \mathrm{E}-07$ \\
\hline Cumulative & $0.00 \mathrm{E}+00$ & $0.00 \mathrm{E}+00$ & $3.35 \mathrm{E}-08$ & $2.43 \mathrm{E}-07$ \\
\hline \multirow{2}{*}{$\begin{array}{l}{ }^{136} \mathrm{Xe} \\
\text { Cumulative }\end{array}$} & & & $5.03 \mathrm{E}-08$ & $3.19 \mathrm{E}-07$ \\
\hline & $0.00 \mathrm{E}+00$ & $0.00 \mathrm{E}+00$ & $5.03 \mathrm{E}-08$ & 3.69E-07 \\
\hline \multirow{2}{*}{\begin{tabular}{|l|}
$\Sigma \mathrm{Xe}$ \\
Cumulative \\
\end{tabular}} & $0.00 \mathrm{E}+00$ & $0.00 \mathrm{E}+00$ & $1.24 \mathrm{E}-07$ & $7.42 \mathrm{E}-07$ \\
\hline & $0.00 \mathrm{E}+00$ & $0.00 \mathrm{E}+00$ & $1.24 \mathrm{E}-07$ & $8.66 \mathrm{E}-07$ \\
\hline
\end{tabular}


Estimated quantities of uranium metal corroded by Reactions 1-3 given in Table 4.11 are $0.026 \mathrm{wt} \%$ and $0.0032 \mathrm{wt} \%$ for $\mathrm{KC}-6$ and $96-06$, respectively, and are comparable to the uranium metal concentrations estimated for the other tests in Series II, except for KC-1 P500. Reaction 1 (to produce $\mathrm{H}_{2}$ ) comprises about $40 \%$ of the total uranium metal corrosion in both tests. The net production of $\mathrm{N}_{2}$ in the 96-06 test negates a substantial fraction of the estimated uranium corroded by reactions with water and $\mathrm{O}_{2}$.

$\mathrm{The} \mathrm{Kr}$ and $\mathrm{Xe}$ isotope concentrations were below detection limits for the $\mathrm{KC}-6$ test, making it impossible to predict uranium metal concentration based on fission product gas release. The uranium metal concentrations based on $\mathrm{Kr}$ and $\mathrm{Xe}$ release are similar (each about $0.9 \mathrm{wt} \%$ ) for the 96-06 sludge and are almost 300 times higher than predicted based on the corrosion gas analyses. Like the situation found for the $\mathrm{KC}-6$ sludge tests, consumption of freed $\mathrm{H}_{2}$ by reaction with $\mathrm{U}(\mathrm{VI})$ compounds in the uranium-rich 96-06 sludge may have been responsible for the apparent shortfall in $\mathrm{H}_{2}$ gas evolution by uranium reaction with water.

Because of the long sample storage period ( $\sim 4$ years) and the fact that the sample dried out, the original uranium metal content of 96-06, at the time of sampling, cannot be confidently estimated.

Because of the low (undetectable) $\mathrm{Kr}$ and $\mathrm{Xe}$ gas concentrations, no evaluation of isotopic compositions, cooling time, or uranium metal concentration could be made for the KC-6 sludge. The $\mathrm{Kr}$ and Xe isotope distributions for the 96-06 test are similar to those predicted by ORIGEN (Table 4.12). The ${ }^{85} \mathrm{Kr}$ decay corresponds to a cooling time of about 14 years or about the last time $\mathrm{N}$ Reactor was at power.

The hydrocarbon concentrations in the KC-6 and 96-06 sludges are 0.082 and $0.37 \mathrm{ppm}$, respectively, and are lower than all other tests in this series except those of KC-1 Un and FE-5 (0.030 and 0.33 ppm). Methane comprises $56 \%$ and $21 \%$ of the carbon in the evolved hydrocarbon, respectively, in contrast to

Table 4.11. Reacted Metallic Uranium Calculated from Gas Generation and Consumption Reactions in KC-6 and 96-06 Tests

\begin{tabular}{|c|c|c|}
\hline \multirow[t]{2}{*}{ Reaction } & \multicolumn{2}{|c|}{ U Reacted Based on Various Reactions, moles } \\
\hline & KC-6 & $96-06$ \\
\hline $\begin{array}{l}\text { Settled Sludge } \\
\text { Mass in Test, g }\end{array}$ & 19.10 & 19.51 \\
\hline $\begin{array}{c}\text { Reaction 1 } \\
\mathrm{U}+2 \mathrm{H}_{2} \mathrm{O} \rightarrow \mathrm{UO}_{2}+2 \mathrm{H}_{2}\end{array}$ & $9.43 \mathrm{E}-6$ & $1.10 \mathrm{E}-6$ \\
\hline $\begin{array}{l}\text { Reaction } 2 \\
\mathrm{U}+\mathrm{O}_{2} \rightarrow \mathrm{UO}_{2} \\
\end{array}$ & 7.04E-6 & $7.25 \mathrm{E}-6$ \\
\hline $\begin{array}{c}\text { Reaction 3 } \\
\mathrm{U}+0.875 \mathrm{~N}_{2} \rightarrow \mathrm{UN}_{1.75}\end{array}$ & $3.98 \mathrm{E}-6$ & $-5.69 \mathrm{E}-6$ \\
\hline $\begin{array}{c}\text { Total Moles U } \\
(\Sigma \text { Reactions 1-3) }\end{array}$ & $2.05 \mathrm{E}-5$ & $2.66 \mathrm{E}-6$ \\
\hline $\begin{array}{l}\text { U metal, wt\% } \\
\text { settled sludge, } \\
\text { Reactions } 1-3\end{array}$ & 0.0255 & 0.00325 \\
\hline $\begin{array}{c}\text { U metal, wt } \% \\
\text { settled sludge, } \mathrm{Kr}\end{array}$ & -- & 0.804 \\
\hline $\begin{array}{c}\text { U metal, wt } \% \\
\text { settled sludge, } \mathrm{Xe}\end{array}$ & -- & 0.990 \\
\hline
\end{tabular}


Table 4.12. Isotope Ratios for 96-06 Test

\begin{tabular}{|c|c|c|}
\hline Gas & Isotopic Composition, atom\% & ORIGEN $^{(\mathbf{a})}$ \\
\hline${ }^{83} \mathrm{Kr}$ & 17.4 & 13.3 \\
\hline${ }^{84} \mathrm{Kr}$ & 29.9 & 28.3 \\
\hline${ }^{85} \mathrm{Kr}$ & 2.8 & 6.8 \\
\hline${ }^{86} \mathrm{Kr}$ & 49.9 & 51.5 \\
\hline${ }^{130} \mathrm{Xe}$ & 0.0 & 0.05 \\
\hline${ }^{131} \mathrm{Xe}$ & 11.1 & 10.7 \\
\hline${ }^{132} \mathrm{Xe}$ & 18.2 & 18.0 \\
\hline${ }^{134} \mathrm{Xe}$ & 28.0 & 28.0 \\
\hline${ }^{136} \mathrm{Xe}$ & 42.6 & 43.2 \\
\hline $\mathrm{Xe}: \mathrm{Kr}$ & 9.9 & 8.2 \\
\hline
\end{tabular}

(a) ORIGEN2 calculation for N Reactor MkIV fuel at $2921 \mathrm{MWD} / \mathrm{TeU}$; ratios change $<3 \%$ relative at lower burnups; ${ }^{85} \mathrm{Kr}$ has a 10.76 -year half-life.

$70-80 \%$ in the tests with $\mathrm{KC}-1$ sludge. The carbide concentration is apparently 315 ppmp uranium metal, based on the reaction gas $\left(\mathrm{H}_{2}, \mathrm{O}_{2}\right.$, and $\left.\mathrm{N}_{2}\right)$ result from the $\mathrm{KC}-6$ sludge, and is consistent with the concentration expected in the fuel. The carbide concentration inferred for the $96-06$ sludge is $41 \mathrm{ppmp}$ uranium and is unusually low.

Again, $\mathrm{CO}_{2}$ comprises most of the gas product in the $\mathrm{KC}-6$ and 96-06 sludge tests, corresponding to 66and 20-ppm lower limits in inorganic carbon concentration, respectively. The inorganic carbon concentrations found by chemical characterization of the 96-06 dry sludge is about $600 \mathrm{ppm}$ (i.e., about $300 \mathrm{ppm}$ for the as-settled sludge), and thus is much higher than found by release of $\mathrm{CO}_{2}$.

\subsection{Conclusions}

Several conclusions were drawn from the Series II testing and from analyses of the data derived from the various tests:

- Overall, the sludge samples evaluated in the Series II tests were relatively benign and unreactive, as demonstrated by their low gas generation rates. In comparison, the KE canister and floor sludge tested in Series I exhibited a higher uranium metal content than similar sludge tested in Series II. Because the sludge material used in Series II was stored for a longer period of time at slightly elevated temperatures, the Series I results more accurately reflect the uranium metal content of the sludge in the KE Basin.

- For certain sludge samples in Series II, use of fission product gas ( $\mathrm{Kr}$ and $\mathrm{Xe}$ ) release data resulted in a higher and more accurate estimation of the uranium metal content in comparison with the corrosion gas $\left(\mathrm{H}_{2}, \mathrm{O}_{2}, \mathrm{~N}_{2}\right)$ data.

- Canister sludge that had been stored wet in a shielded facility for 14 months at $\sim 32^{\circ} \mathrm{C}$, after sample collection, contained about $0.56 \mathrm{wt} \%$ uranium metal (based on analysis of the release of fission product gases).

- Testing with canister sludge (stored for 14 months at $32^{\circ} \mathrm{C}$ ) showed that very little metallic uranium is present in the material containing particles less than $500 \mu \mathrm{m}$. 
- Aggressive agitation and sieving of canister sludge resulted in a 9X increase in the quantity of uranium metal that reacted over the test period (i.e., without agitation, $0.065 \mathrm{wt} \%$ of sample reacted; with agitation, $0.56 \mathrm{wt} \%$ of sample reacted.)

- The single-pull core floor and pit sludge samples displayed very low chemical reactivity, provided little gas generation, and are estimated to contain 0.0013 to $0.027 \mathrm{wt} \%$ metallic uranium (settled sludge basis).

- Sludge that consisted primarily of organic ion exchange resin beads generated very little gas even after 950 hours at temperatures of $90^{\circ} \mathrm{C}$ and $95^{\circ} \mathrm{C}$. It is estimated that this material contains about $0.026 \mathrm{wt} \%$ uranium metal.

- Archived canister sludge from the 1996 sampling campaign no longer demonstrated significant reactivity. Based on analysis of the release of fission product gases, this sludge was estimated to contain about $0.9 \mathrm{wt} \%$ uranium metal (settled sludge basis). 


\subsection{References}

Baker, R. B., T. L. Welsh, and B. J. Makenas. 2000. Sampling and Analysis Plan for Sludge from the 105-K Basins to Support Transport to and Storage in T Plant. HNF-6479, Rev. 0, Fluor Hanford, Inc., Richland, Washington.

Bradley, M. J., and L. M. Ferris. 1962. "Hydrolysis of Uranium Carbides between 25 and $100^{\circ}$. I. Uranium Monocarbide." Inorganic Chemistry 1(3):683-687.

Bradley, M. J., and L. M. Ferris. 1964. "Hydrolysis of Uranium Carbides between 25 and 100'. II. Uranium Dicarbide, Uranium Metal-Monocarbide Mixtures, and Uranium Monocarbide-Dicarbide Mixtures.” Inorganic Chemistry 3(2):189-195.

Bredt, P. R., C. H. Delegard, A. J. Schmidt, and K. L. Silvers. 1999. Testing and Analysis of Consolidated Sludge Sample from 105K East Basin Floor and Canisters. PNNL-13341, Pacific Northwest National Laboratory, Richland, Washington.

Bredt, P. R., C. H. Delegard, A. J. Schmidt, K. L. Silvers, B. M. Thornton, and S. R. Gano. 2000. Particle Size (Sieving) and Enthalpy (Acid Calorimetry) Analysis of Single-Pull K East Basin Floor and Pit Sludges. PNNL-13373, Pacific Northwest National Laboratory, Richland, Washington.

Bryan, S. A., and L. R. Pederson. 1995. Thermal and Combined Thermal and Radiolytic Reactions Involving Nitrous Oxide, Hydrogen, and Nitrogen in the Gas Phase: Comparison of Gas Generation Rates in Supernate and Solid Fractions of Tank 241-SY-101 Simulated Wastes. PNL-10490, Pacific Northwest National Laboratory, Richland, Washington.

Bryan, S. A., L. R. Pederson, C. M. King, S. V. Forbes, and R. L. Sell. 1996. Gas Generation from Tank 241-SY-103 Waste. PNL-10798, Pacific Northwest National Laboratory, Richland, Washington.

Cordfunke, E.H.P. 1969. The Chemistry of Uranium, p. 188. Elsevier Publishing Company, Amsterdam, Netherlands.

Delegard, C. H., S. A. Bryan, A. J. Schmidt, P. R. Bredt, C. M. King, R. L. Sell, L. L. Burger, and K. L. Silvers. 2000. Gas Generation from K East Basin Sludges - Series I Testing. PNNL-13320, Pacific Northwest National Laboratory, Richland, Washington.

Elmore, M. R., A. J. Schmidt, K. L. Silvers, B. M. Thornton, and S. R. Gano. 2000. Chemical and Radiochemical Analysis of Consolidated Sludge Samples from K East Basin. PNNL-13360, Pacific Northwest National Laboratory, Richland, Washington.

Gillies, D. M. 1958. "Some Studies of the Reactions of Uranium Oxides with Hydrogen, Oxygen, and Water." In Chemistry of Uranium -- Collected Papers, TID-5290, pp. 746-747, Paper 76, J. J. Katz and E. Rabinowitch, editors. United States Atomic Energy Commission, Oak Ridge, Tennessee.

Johnson, A. B., R. G. Ballinger, and K. A. Simpson. 1994. "Kinetic and Thermodynamic Bases to Resolve Issues Regarding Conditioning of Uranium Metal Fuels." PNL-SA-24458, Pacific Northwest Laboratory, Richland, Washington. 
King, C. M., L. R. Pederson, and S. A. Bryan. 1997. Thermal and Radiolytic Gas Generation from Tank 241-S-102 Waste. PNNL-11600, Pacific Northwest National Laboratory, Richland, Washington.

Makenas, B. J., T. L. Welsh, R. B. Baker, D. R. Hansen, and G. R. Golcar. 1996. Analysis of Sludge from Hanford K East Basin Floor and Weasel Pit. WHC-SP-1182, Westinghouse Hanford Company, Richland, Washington.

Makenas, B. J., T. L. Welsh, R. B. Baker, E. W. Hoppe, A. J. Schmidt, J. Abrefah, J. M. Tingey, P. R. Bredt, and G. R. Golcar. 1997. Analysis of Sludge from Hanford K East Basin Canisters. HNF-SP-1201, DE\&S Hanford, Inc., Richland, Washington.

Makenas, B. J., T. L. Welsh, R. B. Baker, G. R. Golcar, P. R. Bredt, A. J. Schmidt, and J. M. Tingey. 1998. Analysis of Sludge from Hanford K West Basin Canisters. HNF-1728, Rev. 0, Fluor Daniel Hanford, Richland, Washington.

Makenas, B. J., A. J. Schmidt, K. L. Silvers, P. R. Bredt, C. H. Delegard, E. W. Hoppe, J. M. Tingey, A. H. Zacher, T. L. Welsh, R. B. Baker. 1999. Supplementary Information on K-Basin Sludges. HNF-2367, Rev. 0, Fluor Daniel Hanford, Richland, Washington.

Makenas, B. J. 2000. Data Quality Objectives for Analysis of Hanford K Basin Sludge to Support Transport to and Storage in T Plant. HNF-5345, Rev. 0, Fluor Hanford, Inc., Richland, Washington.

Marschman, S. C., T. D. Pyecha, and J. Abrefah. 1997. Metallographic Examination of Damaged N Reactor Spent Nuclear Fuel Element SFEC5,4378. PNNL-11438, Pacific Northwest National Laboratory, Richland, Washington.

Montenyohl, V. I. 1960. "Corrosion of Uranium." Chapter 7, Reactor Handbook, $2^{\text {nd }}$ edition, Vol. I, Materials, C. R. Tipton, Jr., editor. Interscience Publishers, Inc., New York.

Pajunen, A. L. 1999. Uranium Oxidation Rate Summary for the Spent Nuclear Fuel Project. HNF-4165, Rev. 0, DE\&S Hanford, Inc., Richland, Washington.

Pearce, K. L., and S. C. Klimper. 2000. 105-K Basin Material Design Basis Feed Description for Spent Nuclear Fuel Project Facilities, Volume 2, Sludge. HNF-SD-SNF-TI-009, Rev. 3, Fluor Hanford, Inc., Richland, Washington.

Pitner, A. L. 1999. K East Basin Sludge/Sampling 1999 Campaigns. HNF-4746, Rev. 0, Numatec Hanford Corporation, Richland, Washington.

Reilly, M. A. 1998. Spent Nuclear Fuel Project Technical Databook, Volume 1. HNF-SD-SNF-TI-015, Rev. 6, DE\&S Hanford, Inc., Richland, Washington.

Sandino, M., C. Amaia, and B. Grambow. 1994. "Solubility Equilibria in the U(VI)-Ca-K-Cl- $\mathrm{H}_{2} \mathrm{O}$ System: Transformation of Schoepite into Becquerelite and Compreignacite." Radiochimica Acta 66/67:37-43. 
Schmidt, A. J., G. S. Klinger, and P. R. Bredt. 1998. Evaluation of Ion Exchange Materials in K Basin Floor Sludge and Potential Solvents for PCB Extraction from Ion Exchange Materials. PNNL-12108, Pacific Northwest National Laboratory, Richland, Washington.

Sowder, A. G., S. B. Clark, and R. A. Fjeld. 1996. "The Effect of Silica and Phosphate on the Transformation of Schoepite to Becquerelite and Other Uranyl Phases." Radiochimica Acta 74:45-49.

Sowder, A. G., S. B. Clark, and R. A. Fjeld. 1999. "The Transformation of Uranyl Oxide Hydrates: The Effect of Dehydration on Synthetic Metaschoepite and Its Alteration to Becquerelite." Environmental Science and Technology 33:3552-3557.

Steen, F. H. 2000. K-East Basin Floor and Pit Composite Sludge Samples, Analytical Results for the Final Report. HNF-6053, Rev. 0A, Fluor Hanford, Inc., Richland, Washington.

Troutner, V. H. 1960. Mechanisms and Kinetics of Uranium Corrosion and Uranium Core Fuel Element Ruptures in Water and Steam. HW-67370, Hanford Atomic Products Operation, Richland, Washington.

Tyfield, S. P. 1988. "Corrosion of Reactor Grade Uranium in Aqueous Solutions Relevant to Storage and Transport." Nuclear Engineering 27(2):91-98.

Vochten, R., and L. Van Haverbeke. 1990. "Transformation of Schoepite into the Uranyl Oxide Hydrates: Becquerelite, Billietite and Wölsendorfite." Mineralogy and Petrology 43:65-72.

Waber, J. T. 1956. A Review of the Corrosion Behavior of Uranium. LA-2035, Los Alamos Scientific Laboratory, Los Alamos, New Mexico.

Weakley, E. A. 1979. Fuels Engineering Technical Handbook. UNI-M-61, UNC Nuclear Industries, Richland, Washington.

Wilkinson, W. D. 1962. Uranium Metallurgy, Interscience Publishers, New York.

Wronkiewicz, D. J., J. K. Bates, S. F. Wolf, and E. C. Buck. 1996. “Ten-Year Results from Unsaturated Drip Tests with $\mathrm{UO}_{2}$ at $90^{\circ} \mathrm{C}$ : Implications for the Corrosion of Spent Nuclear Fuel." Journal of Nuclear Materials 238:78-95. 


\section{Appendix A}

Gas Analysis and Gas Generation Rate Data 
Table A.1. Gas Analyses for Test KC-1 Un at $60^{\circ} \mathrm{C}$ and $95^{\circ} \mathrm{C}$

\begin{tabular}{|c|c|c|c|c|c|c|c|c|c|c|c|c|c|c|c|c|c|c|c|c|}
\hline $\begin{array}{c}\text { Run } \\
\text { Sys -1 }\end{array}$ & $\begin{array}{c}\text { Temp. } \\
{ }^{\circ} \mathrm{C}\end{array}$ & $\mathrm{Ne}$ & $\mathrm{Ar}$ & $\mathrm{H}_{2}$ & $\mathrm{CO}_{2}$ & $\mathrm{CH}_{4}$ & $\mathrm{C}_{2} \mathrm{HC}$ & $\mathrm{C}_{>2} \mathrm{HC}$ & $\mathrm{N}_{2}$ & $\mathrm{O}_{2}$ & $\mathrm{Kr} 83$ & $\mathrm{Kr} 84$ & Kr 85 & $\mathrm{Kr} 86$ & Xe 130 & Xe 131 & Xe 132 & Xe 134 & Xe 136 & Time, $\mathrm{h}$ \\
\hline \multirow{2}{*}{$\begin{array}{c}1 \\
22 \mathrm{~K} 52\end{array}$} & \multirow{2}{*}{$\begin{array}{c}60 \\
95\end{array}$} & 84.4 & 0.017 & 0.011 & 14.4 & 0.01 & 0.003 & 0.0009 & 1.11 & 0.064 & $3.0 \mathrm{E}-05$ & $5.0 \mathrm{E}-05$ & & $8.0 \mathrm{E}-05$ & & $5.0 \mathrm{E}-04$ & $5.0 \mathrm{E}-04$ & 8.0E-04 & $1.0 \mathrm{E}-03$ & 293 \\
\hline & & & & 0.1 & 99.81 & 0.069 & 0.02 & 0.01 & -1.578 & -2.044 & $2.1 \mathrm{E}-04$ & $3.5 \mathrm{E}-04$ & & \begin{tabular}{|l|}
$5.5 \mathrm{E}-04$ \\
\end{tabular} & & $3.5 \mathrm{E}-03$ & $3.5 \mathrm{E}-03$ & \begin{tabular}{|l|}
$5.5 \mathrm{E}-03$ \\
\end{tabular} & 6.9E-03 & 167 \\
\hline \multirow{2}{*}{$\begin{array}{c}2 \\
22 \mathrm{~K} 61\end{array}$} & \multirow[t]{2}{*}{95} & 87.1 & 0.018 & 0.009 & 11.1 & 0.01 & & & 1.48 & 0.29 & $2.0 \mathrm{E}-05$ & \begin{tabular}{|l|}
$4.0 \mathrm{E}-05$ \\
\end{tabular} & $3.0 \mathrm{E}-06$ & $7.0 \mathrm{E}-05$ & & $2.0 \mathrm{E}-04$ & $3.0 \mathrm{E}-04$ & 5.0E-04 & $7.0 \mathrm{E}-04$ & \multirow[t]{2}{*}{477} \\
\hline & & & & 0.1 & 99.80 & 0.099 & & & 0.528 & -0.821 & $1.8 \mathrm{E}-04$ & $3.6 \mathrm{E}-04$ & $2.7 \mathrm{E}-05$ & $6.3 \mathrm{E}-04$ & & $1.8 \mathrm{E}-03$ & $2.7 \mathrm{E}-03$ & $4.5 \mathrm{E}-03$ & $6.3 \mathrm{E}-03$ & \\
\hline
\end{tabular}

Table A.2. Gas Analyses for Test KC-1 Mix at $60^{\circ} \mathrm{C}$ and $95^{\circ} \mathrm{C}$

\begin{tabular}{|c|c|c|c|c|c|c|c|c|c|c|c|c|c|c|c|c|c|c|c|c|}
\hline $\begin{array}{c}\text { Run } \\
\text { Sys -2 }\end{array}$ & $\begin{array}{c}\text { Temp. } \\
{ }^{\circ} \mathrm{C}\end{array}$ & $\mathrm{Ne}$ & $\mathrm{Ar}$ & $\mathrm{H}_{2}$ & $\mathrm{CO}_{2}$ & $\mathrm{CH}_{4}$ & $\mathrm{C}_{2} \mathrm{HC}$ & $\mathrm{C}_{>2} \mathrm{HC}$ & $\mathrm{N}_{2}$ & $\mathrm{O}_{2}$ & Kr 83 & $\mathrm{Kr} 84$ & $\mathrm{Kr} 85$ & $\mathrm{Kr} 86$ & Xe 130 & Xe 131 & Xe 132 & Xe 134 & Xe 136 & Time, $\mathrm{h}$ \\
\hline \multirow{2}{*}{$\begin{array}{c}1 \\
22 \mathrm{~K} 52 \\
\end{array}$} & \multirow{2}{*}{$\begin{array}{l}60 \\
95\end{array}$} & 86.6 & 0.016 & 0.084 & 11.8 & 0.24 & 0.023 & 0.005 & 1.03 & 0.19 & $6.0 \mathrm{E}-04$ & 8.0E-04 & $6.0 \mathrm{E}-05$ & $1.3 \mathrm{E}-03$ & & $1.9 \mathrm{E}-03$ & 2.9E-03 & 4.6E-03 & 6.7E-03 & \multirow{2}{*}{$\begin{array}{l}330 \\
167 \\
\end{array}$} \\
\hline & & & & 0.7 & 96.95 & 1.972 & 0.19 & 0.04 & -1.84 & -1.20 & $4.9 \mathrm{E}-03$ & $6.6 \mathrm{E}-03$ & $4.9 \mathrm{E}-04$ & $1.1 \mathrm{E}-02$ & & $1.6 \mathrm{E}-02$ & $2.4 \mathrm{E}-02$ & $3.8 \mathrm{E}-02$ & $5.5 \mathrm{E}-02$ & \\
\hline \multirow{2}{*}{$\begin{array}{c}2 \\
22 \mathrm{~K} 61\end{array}$} & \multirow[t]{2}{*}{95} & 90 & 0.019 & 0.094 & 7.6 & 0.34 & 0.023 & 0.004 & 1.57 & 0.38 & $2.0 \mathrm{E}-04$ & $5.0 \mathrm{E}-04$ & $4.0 \mathrm{E}-05$ & $9.0 \mathrm{E}-04$ & $3.0 \mathrm{E}-06$ & \begin{tabular}{|l|}
$1.0 \mathrm{E}-03$ \\
\end{tabular} & \begin{tabular}{|l|}
$1.6 \mathrm{E}-03$ \\
\end{tabular} & $2.8 \mathrm{E}-03$ & $4.0 \mathrm{E}-03$ & \multirow[t]{2}{*}{477} \\
\hline & & & & 1.2 & 94.15 & 4.21 & 0.28 & 0.05 & 0.81 & -0.29 & $2.5 \mathrm{E}-03$ & $6.2 \mathrm{E}-03$ & $5.0 \mathrm{E}-04$ & $1.1 \mathrm{E}-02$ & $3.7 \mathrm{E}-05$ & $1.2 \mathrm{E}-02$ & $2.0 \mathrm{E}-02$ & $3.5 \mathrm{E}-02$ & $5.0 \mathrm{E}-02$ & \\
\hline
\end{tabular}

Table A.3. Gas Generation Rates from $\mathrm{KC}-1 \mathrm{Un}$ at $60^{\circ} \mathrm{C}$ and $95^{\circ} \mathrm{C}$

\begin{tabular}{|c|c|c|c|c|c|c|c|c|c|c|c|c|c|c|c|c|c|c|}
\hline \multirow[t]{2}{*}{ Run } & \multirow{2}{*}{$\underset{\substack{\text { Temp. } \\
{ }^{\circ} \mathrm{C}}}{ }$} & \multicolumn{17}{|c|}{ Gas Generation Rate, moles/kg-day } \\
\hline & & $\mathrm{H}_{2}$ & $\mathrm{CO}_{2}$ & $\mathrm{CH}_{4}$ & $\mathrm{C}_{2} \mathrm{HC}$ & $\mathrm{C}_{>2} \mathrm{HC}$ & $\mathrm{N}_{2}$ & $\mathrm{O}_{2}$ & $\mathrm{Kr} 83$ & $\mathrm{Kr} 84$ & $\mathrm{Kr} 85$ & $\mathrm{Kr} 86$ & Xe 130 & Xe 131 & Xe 132 & Xe 134 & Xe 136 & Time, $\mathrm{h}$ \\
\hline 1 & $\begin{array}{c}60 \\
95\end{array}$ & $6.65 \mathrm{E}-07$ & $8.71 \mathrm{E}-04$ & $6.0 \mathrm{E}-07$ & $1.8 \mathrm{E}-7$ & $5.4 \mathrm{E}-8$ & $-1.4 \mathrm{E}-05$ & $-1.8 \mathrm{E}-05$ & $1.8 \mathrm{E}-9$ & $3.0 \mathrm{E}-9$ & & $4.8 \mathrm{E}-9$ & & $3.0 \mathrm{E}-8$ & $3.0 \mathrm{E}-8$ & $4.8 \mathrm{E}-8$ & $6.0 \mathrm{E}-8$ & $\begin{array}{l}293 \\
167 \\
\end{array}$ \\
\hline 2 & 95 & $5.05 \mathrm{E}-07$ & $6.23 \mathrm{E}-04$ & $6.2 \mathrm{E}-07$ & & & $3.3 \mathrm{E}-06$ & $-5.1 \mathrm{E}-06$ & $1.1 \mathrm{E}-9$ & $2.2 \mathrm{E}-9$ & $1.7 \mathrm{E}-10$ & $3.9 \mathrm{E}-9$ & & $1.1 \mathrm{E}-8$ & $1.7 \mathrm{E}-8$ & $2.8 \mathrm{E}-8$ & $3.9 \mathrm{E}-8$ & 477 \\
\hline
\end{tabular}

Table A.4. Gas Generation Rates from $\mathrm{KC}-1 \mathrm{Mix}$ at $60^{\circ} \mathrm{C}$ and $95^{\circ} \mathrm{C}$

\begin{tabular}{|c|c|c|c|c|c|c|c|c|c|c|c|c|c|c|c|c|c|c|}
\hline \multirow[t]{2}{*}{ Run } & \multirow{2}{*}{$\begin{array}{c}\text { Temp. } \\
{ }^{\circ} \mathrm{C}\end{array}$} & \multicolumn{17}{|c|}{ Gas Generation Rate, moles/kg-day } \\
\hline & & \begin{tabular}{|l|}
$\mathrm{H}_{2}$ \\
\end{tabular} & \begin{tabular}{|l|}
$\mathrm{CO}_{2}$ \\
\end{tabular} & $\mathrm{CH}_{4}$ & $\mathrm{C}_{2} \mathrm{HC}$ & $\mathrm{C}_{>2} \mathrm{HC}$ & $\mathrm{N}_{2}$ & \begin{tabular}{|l|}
$\mathrm{O}_{2}$ \\
\end{tabular} & $\mathrm{Kr} 83$ & $\mathrm{Kr} 84$ & $\mathrm{Kr} 85$ & $\mathrm{Kr} 86$ & Xe 130 & Xe 131 & Xe 132 & Xe 134 & Xe 136 & Time, $\mathrm{h}$ \\
\hline 1 & $\begin{array}{l}60 \\
95\end{array}$ & $4.52 \mathrm{E}-06$ & $6.36 \mathrm{E}-04$ & $1.3 \mathrm{E}-05$ & $1.2 \mathrm{E}-6$ & $2.7 \mathrm{E}-7$ & $-1.2 \mathrm{E}-05$ & $-7.9 \mathrm{E}-06$ & $3.2 \mathrm{E}-8$ & $4.3 \mathrm{E}-8$ & $3.2 \mathrm{E}-9$ & $7.0 \mathrm{E}-8$ & & $1.0 \mathrm{E}-7$ & $1.6 \mathrm{E}-7$ & $2.5 \mathrm{E}-7$ & $3.6 \mathrm{E}-7$ & $\begin{array}{l}330 \\
167\end{array}$ \\
\hline 2 & 95 & $5.07 \mathrm{E}-06$ & $4.10 \mathrm{E}-04$ & $1.8 \mathrm{E}-05$ & $1.2 \mathrm{E}-6$ & $2.2 \mathrm{E}-7$ & $3.5 \mathrm{E}-06$ & $-1.3 \mathrm{E}-06$ & $1.1 \mathrm{E}-8$ & $2.7 \mathrm{E}-8$ & $2.2 \mathrm{E}-9$ & 4.9E-8 & $1.6 \mathrm{E}-10$ & $5.4 \mathrm{E}-8$ & $8.6 \mathrm{E}-8$ & $1.5 \mathrm{E}-7$ & $2.2 \mathrm{E}-7$ & 477 \\
\hline
\end{tabular}


Table A.5. Gas Analyses for Test $\mathrm{KC}-1 \mathrm{P} 500$ at $80^{\circ} \mathrm{C}$ and $95^{\circ} \mathrm{C}$

\begin{tabular}{|c|c|c|c|c|c|c|c|c|c|c|c|c|c|c|c|c|c|c|c|c|}
\hline $\begin{array}{c}\text { Run } \\
\text { Sys -3 }\end{array}$ & $\begin{array}{c}\text { Temp. } \\
{ }^{\circ} \mathrm{C}\end{array}$ & $\mathrm{Ne}$ & $\mathrm{Ar}$ & $\mathrm{H}_{2}$ & $\mathrm{CO}_{2}$ & $\mathrm{CH}_{4}$ & $\mathrm{C}_{2} \mathrm{HC}$ & $\mathrm{C}_{>2} \mathrm{HC}$ & $\mathrm{N}_{2}$ & $\mathrm{O}_{2}$ & $\mathrm{Kr} 83$ & $\mathrm{Kr} 84$ & Kr 85 & $\mathrm{Kr} 86$ & Xe 130 & Xe 131 & Xe 132 & Xe 134 & Xe 136 & Time, $\mathrm{h}$ \\
\hline \multirow{2}{*}{$\begin{array}{c}1 \\
22 \mathrm{~K} 52\end{array}$} & \multirow{2}{*}{$\begin{array}{c}80 \\
95\end{array}$} & 73.7 & 0.015 & 20 & 4.36 & 0.71 & 0.079 & 0.025 & 0.89 & 0.076 & $2.4 \mathrm{E}-03$ & $4.2 \mathrm{E}-03$ & $6.0 \mathrm{E}-04$ & $7.0 \mathrm{E}-03$ & $3.0 \mathrm{E}-05$ & $1.3 \mathrm{E}-02$ & $2.0 \mathrm{E}-02$ & $3.3 \mathrm{E}-02$ & $4.9 \mathrm{E}-02$ & \multirow{2}{*}{$\begin{array}{l}326 \\
166 \\
\end{array}$} \\
\hline & & & & 79.04 & 17.23 & 2.806 & 0.312 & 0.099 & -1.108 & -0.941 & $9.5 \mathrm{E}-03$ & \begin{tabular}{|l|}
$1.7 \mathrm{E}-02$ \\
\end{tabular} & $2.4 \mathrm{E}-03$ & $2.8 \mathrm{E}-02$ & $1.2 \mathrm{E}-04$ & \begin{tabular}{|l|}
$5.1 \mathrm{E}-02$ \\
\end{tabular} & 7.9E-02 & \begin{tabular}{|l|}
$1.3 \mathrm{E}-01$ \\
\end{tabular} & 1.9E-01 & \\
\hline \multirow{2}{*}{$\begin{array}{c}2 \\
22 \mathrm{~K} 61\end{array}$} & \multirow[t]{2}{*}{95} & 87.6 & 0.022 & 5.7 & 4.1 & 0.19 & 0.031 & 0.012 & 1.8 & 0.44 & $5.0 \mathrm{E}-04$ & \begin{tabular}{|l|}
$8.0 \mathrm{E}-04$ \\
\end{tabular} & $1.0 \mathrm{E}-04$ & \begin{tabular}{|l|}
$1.0 \mathrm{E}-03$ \\
\end{tabular} & $4.0 \mathrm{E}-06$ & \begin{tabular}{|l|}
$2.3 \mathrm{E}-03$ \\
\end{tabular} & $3.8 \mathrm{E}-03$ & $6.4 \mathrm{E}-03$ & $9.5 \mathrm{E}-03$ & \multirow[t]{2}{*}{477} \\
\hline & & & & 56.7 & 40.77 & 1.889 & 0.31 & 0.12 & 0.441 & -0.308 & 5.0E-03 & $8.0 \mathrm{E}-03$ & $9.9 \mathrm{E}-04$ & $9.9 \mathrm{E}-03$ & $4.0 \mathrm{E}-05$ & $2.3 \mathrm{E}-02$ & $3.8 \mathrm{E}-02$ & $6.4 \mathrm{E}-02$ & $9.4 \mathrm{E}-02$ & \\
\hline
\end{tabular}

Table A.6. Gas Analyses for Test $\mathrm{KC}-1 \mathrm{M} 500$ at $80^{\circ} \mathrm{C}$ and $95^{\circ} \mathrm{C}$

\begin{tabular}{|c|c|c|c|c|c|c|c|c|c|c|c|c|c|c|c|c|c|c|c|c|}
\hline $\begin{array}{c}\text { Run } \\
\text { Sys -4 }\end{array}$ & $\begin{array}{c}\text { Temp. } \\
{ }^{\circ} \mathrm{C}\end{array}$ & $\mathrm{Ne}$ & $\mathrm{Ar}$ & $\mathrm{H}_{2}$ & $\mathrm{CO}_{2}$ & $\mathrm{CH}_{4}$ & $\mathrm{C}_{2} \mathrm{HC}$ & $\mathrm{C}_{>2} \mathrm{HC}$ & $\mathrm{N}_{2}$ & $\mathrm{O}_{2}$ & $\operatorname{Kr} 83$ & $\mathrm{Kr} 84$ & $\mathrm{Kr} 85$ & $\mathrm{Kr} 86$ & Xe 130 & Xe 131 & Xe 132 & Xe 134 & Xe 136 & Time, $\mathrm{h}$ \\
\hline \multirow{2}{*}{$\begin{array}{c}1 \\
22 \mathrm{~K} 52\end{array}$} & \multirow{2}{*}{$\begin{array}{l}80 \\
95 \\
\end{array}$} & 83.8 & 0.015 & 0.029 & 15 & 0.06 & 0.007 & 0.002 & 0.95 & 0.18 & & $3.0 \mathrm{E}-04$ & $2.0 \mathrm{E}-05$ & $6.0 \mathrm{E}-04$ & & $9.0 \mathrm{E}-04$ & $1.3 \mathrm{E}-03$ & $2.0 \mathrm{E}-03$ & $2.9 \mathrm{E}-03$ & \multirow{2}{*}{$\begin{array}{l}321 \\
166 \\
\end{array}$} \\
\hline & & & & 0.19 & 99.3 & 0.40 & 0.05 & 0.01 & -1.459 & -0.887 & & $2.0 \mathrm{E}-03$ & $1.3 \mathrm{E}-04$ & $4.0 \mathrm{E}-03$ & & $6.0 \mathrm{E}-03$ & $8.6 \mathrm{E}-03$ & $1.3 \mathrm{E}-02$ & $1.9 \mathrm{E}-02$ & \\
\hline \multirow{2}{*}{$\begin{array}{c}2 \\
22 \mathrm{~K} 61\end{array}$} & \multirow[t]{2}{*}{95} & 86.7 & 0.018 & 0.046 & 11.3 & 0.04 & & & 1.48 & 0.375 & $2.0 \mathrm{E}-05$ & $3.0 \mathrm{E}-05$ & $3.0 \mathrm{E}-06$ & $6.0 \mathrm{E}-05$ & & $2.0 \mathrm{E}-04$ & $3.0 \mathrm{E}-04$ & $4.0 \mathrm{E}-04$ & $6.0 \mathrm{E}-04$ & \multirow[t]{2}{*}{477} \\
\hline & & & & 0.40 & 99.2 & 0.33 & & & 0.516 & -0.055 & $1.8 \mathrm{E}-04$ & $2.6 \mathrm{E}-04$ & $2.6 \mathrm{E}-05$ & $5.3 \mathrm{E}-04$ & & $1.8 \mathrm{E}-03$ & $2.6 \mathrm{E}-03$ & $3.5 \mathrm{E}-03$ & $5.3 \mathrm{E}-03$ & \\
\hline
\end{tabular}

Table A.7. Gas Generation Rates from $\mathrm{KC}-1 \mathrm{P} 500$ at $80^{\circ} \mathrm{C}$ and $95^{\circ} \mathrm{C}$

\begin{tabular}{|c|c|c|c|c|c|c|c|c|c|c|c|c|c|c|c|c|c|c|}
\hline \multirow[t]{2}{*}{ Run } & \multirow{2}{*}{$\underset{\substack{\text { Temp. } \\
{ }^{\circ} \mathrm{C}}}{ }$} & \multicolumn{17}{|c|}{ Gas Generation Rate, moles/kg-day } \\
\hline & & \begin{tabular}{|l|}
$\mathrm{H}_{2}$ \\
\end{tabular} & $\mathrm{CO}_{2}$ & $\mathrm{CH}_{4}$ & $\mathrm{C}_{2} \mathrm{HC}$ & $\mathrm{C}_{>2} \mathrm{HC}$ & $\mathrm{N}_{2}$ & $\mathrm{O}_{2}$ & $\mathrm{Kr} 83$ & $\mathrm{Kr} 84$ & $\mathrm{Kr} 85$ & $\mathrm{Kr} 86$ & Xe 130 & Xe 131 & Xe 132 & Xe 134 & Xe 136 & Time, $\mathrm{h}$ \\
\hline 1 & $\begin{array}{l}80 \\
95 \\
\end{array}$ & $1.58 \mathrm{E}-03$ & $3.45 \mathrm{E}-04$ & 5.6E-05 & $6.3 \mathrm{E}-6$ & $2.0 \mathrm{E}-6$ & $-2.2 \mathrm{E}-05$ & $-1.9 \mathrm{E}-05$ & $1.9 \mathrm{E}-7$ & $3.3 \mathrm{E}-7$ & $4.7 \mathrm{E}-8$ & $5.5 \mathrm{E}-7$ & $2.4 \mathrm{E}-9$ & $1.0 \mathrm{E}-6$ & $1.6 \mathrm{E}-6$ & $2.6 \mathrm{E}-6$ & $3.9 \mathrm{E}-6$ & $\begin{array}{l}326 \\
166\end{array}$ \\
\hline 2 & 95 & $3.90 \mathrm{E}-04$ & $2.81 \mathrm{E}-04$ & $1.3 \mathrm{E}-05$ & $2.1 \mathrm{E}-6$ & $8.2 \mathrm{E}-7$ & $3.0 \mathrm{E}-06$ & $-2.1 \mathrm{E}-06$ & $3.4 \mathrm{E}-8$ & $5.5 \mathrm{E}-8$ & $6.8 \mathrm{E}-9$ & $6.8 \mathrm{E}-8$ & $2.7 \mathrm{E}-10$ & $1.6 \mathrm{E}-7$ & $2.6 \mathrm{E}-7$ & $4.4 \mathrm{E}-7$ & $6.5 \mathrm{E}-7$ & 477 \\
\hline
\end{tabular}

Table A.8. Gas Generation Rates from $\mathrm{KC}-1 \mathrm{M} 500$ at $80^{\circ} \mathrm{C}$ and $95^{\circ} \mathrm{C}$

\begin{tabular}{|c|c|c|c|c|c|c|c|c|c|c|c|c|c|c|c|c|c|c|}
\hline \multirow[t]{2}{*}{ Run } & \multirow{2}{*}{$\begin{array}{c}\text { Temp. } \\
{ }^{\circ} \mathrm{C}\end{array}$} & \multicolumn{17}{|c|}{ Gas Generation Rate, moles/kg-day } \\
\hline & & $\mathrm{H}_{2}$ & $\mathrm{CO}_{2}$ & $\mathrm{CH}_{4}$ & $\mathrm{C}_{2} \mathrm{HC}$ & $\mathrm{C}_{>2} \mathrm{HC}$ & $\mathrm{N}_{2}$ & $\mathrm{O}_{2}$ & $\mathrm{Kr} 83$ & $\mathrm{Kr} 84$ & $\mathrm{Kr} 85$ & $\mathrm{Kr} 86$ & Xe 130 & Xe 131 & Xe 132 & Xe 134 & Xe 136 & Time, $\mathrm{h}$ \\
\hline 1 & $\begin{array}{l}80 \\
95\end{array}$ & $1.49 \mathrm{E}-06$ & $7.69 \mathrm{E}-04$ & $3.1 \mathrm{E}-06$ & $3.6 \mathrm{E}-7$ & $1.0 \mathrm{E}-7$ & $-1.1 \mathrm{E}-05$ & $-6.9 \mathrm{E}-06$ & & $1.5 \mathrm{E}-8$ & $1.0 \mathrm{E}-9$ & $3.1 \mathrm{E}-8$ & & $4.6 \mathrm{E}-8$ & $6.7 \mathrm{E}-8$ & $1.0 \mathrm{E}-7$ & $1.5 \mathrm{E}-7$ & \begin{tabular}{|l|}
321 \\
166
\end{tabular} \\
\hline 2 & 95 & $2.32 \mathrm{E}-06$ & 5.70E-04 & $1.9 \mathrm{E}-06$ & & & $3.0 \mathrm{E}-06$ & $-3.2 \mathrm{E}-07$ & $1.0 \mathrm{E}-9$ & $1.5 \mathrm{E}-9$ & $1.5 \mathrm{E}-10$ & $3.0 \mathrm{E}-9$ & & $1.0 \mathrm{E}-8$ & $1.5 \mathrm{E}-8$ & $2.0 \mathrm{E}-8$ & $3.0 \mathrm{E}-8$ & 477 \\
\hline
\end{tabular}


Table A.9. Gas Analyses for Test FE- 1 at $90^{\circ} \mathrm{C}$ and $95^{\circ} \mathrm{C}$

\begin{tabular}{|c|c|c|c|c|c|c|c|c|c|c|c|c|c|c|c|c|c|c|c|c|}
\hline $\begin{array}{c}\text { Run } \\
\text { Sys }-5\end{array}$ & $\begin{array}{c}\text { Temp. } \\
{ }^{\circ} \mathrm{C}\end{array}$ & $\mathrm{Ne}$ & $\mathrm{Ar}$ & $\mathrm{H}_{2}$ & $\mathrm{CO}_{2}$ & $\mathrm{CH}_{4}$ & $\mathrm{C}_{2} \mathrm{HC}$ & $\mathrm{C}_{>2} \mathrm{HC}$ & $\mathrm{N}_{2}$ & $\mathrm{O}_{2}$ & $\mathrm{Kr} 83$ & $\mathrm{Kr} 84$ & $\mathrm{Kr} 85$ & $\mathrm{Kr} 86$ & Xe 130 & \begin{tabular}{|l|}
$\mathrm{Xe}$ \\
131
\end{tabular} & Xe 132 & Xe 134 & Xe 136 & Time, $\mathrm{h}$ \\
\hline \multirow{2}{*}{$\begin{array}{c}1 \\
22 \mathrm{~K} 52\end{array}$} & \multirow{2}{*}{$\begin{array}{c}90 \\
95\end{array}$} & 83.2 & 0.029 & 0.76 & 13.50 & 0.006 & 0.019 & 0.006 & 2.01 & 0.45 & & & & & $2.0 \mathrm{E}-05$ & $1.3 \mathrm{E}-04$ & $2.0 \mathrm{E}-04$ & $5.0 \mathrm{E}-04$ & $5.0 \mathrm{E}-04$ & \multirow{2}{*}{$\begin{array}{l}329 \\
166\end{array}$} \\
\hline & & & & 5.32 & 94.5 & 0.04 & 0.133 & 0.04 & & & & & & & $1.4 \mathrm{E}-04$ & $9.1 \mathrm{E}-04$ & $1.4 \mathrm{E}-03$ & $3.5 \mathrm{E}-03$ & $3.5 \mathrm{E}-03$ & \\
\hline \multirow{2}{*}{$\begin{array}{c}2 \\
22 \mathrm{~K} 61\end{array}$} & \multirow[t]{2}{*}{95} & 84.1 & 0.021 & 0.086 & 13.6 & 0.00 & 0.022 & 0.004 & 1.69 & 0.425 & & & & & & $2.0 \mathrm{E}-05$ & $3.0 \mathrm{E}-05$ & \begin{tabular}{|l|}
$4.0 \mathrm{E}-05$ \\
\end{tabular} & $6.0 \mathrm{E}-05$ & \multirow[t]{2}{*}{477} \\
\hline & & & & 0.63 & 99.2 & 0.01 & 0.16 & 0.03 & & & & & & & & $1.5 \mathrm{E}-04$ & $2.2 \mathrm{E}-04$ & $2.9 \mathrm{E}-04$ & 4.4E-04 & \\
\hline
\end{tabular}

Table A.10. Gas Analyses for Test FE-3 at $90^{\circ} \mathrm{C}$ and $95^{\circ} \mathrm{C}$

\begin{tabular}{|c|c|c|c|c|c|c|c|c|c|c|c|c|c|c|c|c|c|c|c|c|}
\hline $\begin{array}{c}\text { Run } \\
\text { Sys }-6\end{array}$ & $\begin{array}{c}\text { Temp. } \\
{ }^{\circ} \mathrm{C}\end{array}$ & $\mathrm{Ne}$ & $\mathrm{Ar}$ & $\mathrm{H}_{2}$ & $\mathrm{CO}_{2}$ & $\mathrm{CH}_{4}$ & $\mathrm{C}_{2} \mathrm{HC}$ & $\mathrm{C}_{>2} \mathrm{HC}$ & $\mathrm{N}_{2}$ & $\mathrm{O}_{2}$ & $\mathrm{Kr} 83$ & $\mathrm{Kr} 84$ & $\mathrm{Kr} 85$ & $\mathrm{Kr} 86$ & Xe 130 & Xe 131 & Xe 132 & Xe 134 & Xe 136 & Time, $\mathrm{h}$ \\
\hline \multirow{2}{*}{$\begin{array}{c}1 \\
22 \mathrm{~K} 52\end{array}$} & \multirow{2}{*}{$\begin{array}{c}90 \\
95\end{array}$} & 93.1 & 0.027 & 0.01 & 4.7 & 0.003 & 0.006 & 0.005 & 1.78 & 0.36 & & & & & & & & & & \multirow{2}{*}{$\begin{array}{l}327 \\
166\end{array}$} \\
\hline & & & & & 99 & 0.06 & 0.13 & 0.11 & & & & & & & & & & & & \\
\hline \multirow{2}{*}{$\begin{array}{c}2 \\
22 \mathrm{~K} 61 \\
\end{array}$} & \multirow[t]{2}{*}{95} & 93.7 & 0.016 & 0.02 & 4.6 & 0.003 & 0.005 & 0.005 & 1.32 & 0.293 & & & & & & & & & & \multirow[t]{2}{*}{477} \\
\hline & & & & & 99 & 0.06 & 0.11 & 0.11 & & & & & & & & & & & & \\
\hline
\end{tabular}

Table A.11. Gas Analyses for Test FE-5 at $90^{\circ} \mathrm{C}$ and $95^{\circ} \mathrm{C}$

\begin{tabular}{|c|c|c|c|c|c|c|c|c|c|c|c|c|c|c|c|c|c|c|c|c|}
\hline $\begin{array}{c}\text { Run } \\
\text { Sys }-7\end{array}$ & $\begin{array}{c}\text { Temp. } \\
{ }^{\circ} \mathrm{C} \\
\end{array}$ & $\mathrm{Ne}$ & $\mathrm{Ar}$ & $\mathrm{H}_{2}$ & $\mathrm{CO}_{2}$ & $\mathrm{CH}_{4}$ & $\mathrm{C}_{2} \mathrm{HC}$ & $\mathrm{C}_{>2} \mathrm{HC}$ & $\mathrm{N}_{2}$ & $\mathrm{O}_{2}$ & $\mathrm{Kr} 83$ & $\mathrm{Kr} 84$ & $\mathrm{Kr} 85$ & $\mathrm{Kr} 86$ & Xe 130 & Xe 131 & Xe 132 & Xe 134 & Xe 136 & Time, $\mathrm{h}$ \\
\hline \multirow{2}{*}{$\begin{array}{c}1 \\
22 \mathrm{~K} 52\end{array}$} & \multirow{2}{*}{$\begin{array}{l}90 \\
95\end{array}$} & 92.5 & 0.029 & 0.05 & 4.7 & 0.004 & 0.003 & 0.001 & 2.21 & 0.046 & & & & & & $1.0 \mathrm{E}-04$ & $2.0 \mathrm{E}-04$ & $3.0 \mathrm{E}-04$ & \begin{tabular}{|l|}
$5.0 \mathrm{E}-04$ \\
\end{tabular} & \multirow{2}{*}{$\begin{array}{l}327 \\
166 \\
\end{array}$} \\
\hline & & & & 0.94 & 99 & 0.083 & 0.06 & 0.02 & & & & & & & & $2.1 \mathrm{E}-03$ & \begin{tabular}{|l|}
$4.2 \mathrm{E}-03$ \\
\end{tabular} & \begin{tabular}{|l|}
$6.3 \mathrm{E}-03$ \\
\end{tabular} & \begin{tabular}{|l|}
$1.0 \mathrm{E}-02$ \\
\end{tabular} & \\
\hline \multirow{2}{*}{$\begin{array}{c}2 \\
22 \mathrm{~K} 61\end{array}$} & \multirow[t]{2}{*}{95} & 93.1 & 0.02 & 0.06 & 4.9 & 0.005 & 0.003 & 0.003 & 1.6 & 0.333 & & & & & & $6.0 \mathrm{E}-05$ & $9.0 \mathrm{E}-05$ & $1.0 \mathrm{E}-04$ & $2.0 \mathrm{E}-04$ & \multirow[t]{2}{*}{476} \\
\hline & & & & 1.21 & 99 & 0.101 & 0.06 & 0.06 & & & & & & & & $1.2 \mathrm{E}-03$ & $1.8 \mathrm{E}-03$ & $2.0 \mathrm{E}-03$ & \begin{tabular}{|l|}
$4.0 \mathrm{E}-03$ \\
\end{tabular} & \\
\hline
\end{tabular}

Table A.12. Gas Analyses for Test FE-4/6 at $90^{\circ} \mathrm{C}$ and $95^{\circ} \mathrm{C}$

\begin{tabular}{|c|c|c|c|c|c|c|c|c|c|c|c|c|c|c|c|c|c|c|c|c|}
\hline $\begin{array}{c}\text { Run } \\
\text { Sys }-8\end{array}$ & $\begin{array}{c}\text { Temp. } \\
{ }^{\circ} \mathrm{C}\end{array}$ & $\mathrm{Ne}$ & $\mathrm{Ar}$ & $\mathrm{H}_{2}$ & $\mathrm{CO}_{2}$ & $\mathrm{CH}_{4}$ & $\mathrm{C}_{2} \mathrm{HC}$ & $\mathrm{C}_{>2} \mathrm{HC}$ & $\mathrm{N}_{2}$ & $\mathrm{O}_{2}$ & $\mathrm{Kr} 83$ & $\mathrm{Kr} 84$ & $\mathrm{Kr} 85$ & $\mathrm{Kr} 86$ & Xe 130 & Xe 131 & Xe 132 & Xe 134 & Xe 136 & Time, $\mathrm{h}$ \\
\hline \multirow{2}{*}{$\begin{array}{c}1 \\
22 \mathrm{~K} 52 \\
\end{array}$} & \multirow{2}{*}{$\begin{array}{l}90 \\
95\end{array}$} & 86.7 & 0.021 & 0.075 & 11.5 & 0.01 & 0.007 & 0.005 & 1.50 & 0.2 & & & & & $6.0 \mathrm{E}-05$ & $3.0 \mathrm{E}-05$ & $7.0 \mathrm{E}-05$ & $4.0 \mathrm{E}-05$ & $3.0 \mathrm{E}-05$ & \multirow{2}{*}{$\begin{array}{l}326 \\
160\end{array}$} \\
\hline & & & & 0.65 & 99.2 & 0.04 & 0.06 & 0.04 & & & & & & & $5.2 \mathrm{E}-04$ & $2.6 \mathrm{E}-04$ & $6.0 \mathrm{E}-04$ & $3.5 \mathrm{E}-04$ & $2.6 \mathrm{E}-04$ & \\
\hline \multirow{2}{*}{$\begin{array}{c}2 \\
22 \mathrm{~K} 61 \\
\end{array}$} & \multirow[t]{2}{*}{95} & 88.0 & 0.017 & 0.085 & 10.2 & 0.00 & 0.006 & 0.004 & 1.36 & 0.3 & & & & & & & & & & \multirow[t]{2}{*}{477} \\
\hline & & & & 0.83 & 99.0 & 0.04 & 0.06 & 0.04 & & & & & & & & & & & & \\
\hline
\end{tabular}


Table A.13. Gas Generation Rates from FE- 1 at $90^{\circ} \mathrm{C}$ and $95^{\circ} \mathrm{C}$

\begin{tabular}{|c|c|c|c|c|c|c|c|c|c|c|c|c|c|c|c|c|c|c|}
\hline \multirow[t]{2}{*}{ Run } & \multirow{2}{*}{$\begin{array}{c}\text { Temp. } \\
{ }^{\circ} \mathrm{C}\end{array}$} & \multicolumn{17}{|c|}{ Gas Generation Rate, moles/kg-day } \\
\hline & & $\mathrm{H}_{2}$ & $\mathrm{CO}_{2}$ & $\mathrm{CH}_{4}$ & $\mathrm{C}_{2} \mathrm{HC}$ & $\mathrm{C}_{>2} \mathrm{HC}$ & $\mathrm{N}_{2}$ & \begin{tabular}{|l|}
$\mathrm{O}_{2}$ \\
\end{tabular} & $\mathrm{Kr} 83$ & $\mathrm{Kr} 84$ & $\mathrm{Kr} 85$ & $\mathrm{Kr} 86$ & Xe 130 & Xe 131 & $\mathrm{Xe} 132$ & $\mathrm{Xe} 134$ & Xe 136 & Time, $\mathrm{h}$ \\
\hline 1 & $\begin{array}{r}90 \\
95 \\
\end{array}$ & $3.13 \mathrm{E}-05$ & $5 \mid 5.56 \mathrm{E}-04$ & $2.5 \mathrm{E}-07$ & 7.8E-7 & $2.5 \mathrm{E}-7$ & $-1.4 \mathrm{E}-05$ & $-7.3 \mathrm{E}-06$ & & & & & $8.2 \mathrm{E}-10$ & $5.3 \mathrm{E}-9$ & $8.2 \mathrm{E}-9$ & $2.1 \mathrm{E}-8$ & $2.1 \mathrm{E}-8$ & $\begin{array}{l}329 \\
166\end{array}$ \\
\hline 2 & 95 & $3.63 \mathrm{E}-06$ & $55.74 \mathrm{E}-04$ & $8.4 \mathrm{E}-08$ & $9.3 \mathrm{E}-7$ & $1.7 \mathrm{E}-7$ & $7.6 \mathrm{E}-07$ & $-9.9 \mathrm{E}-07$ & & & & & & $8.4 \mathrm{E}-10$ & $1.3 \mathrm{E}-9$ & $1.7 \mathrm{E}-9$ & $2.5 \mathrm{E}-9$ & 477 \\
\hline
\end{tabular}

Table A.14. Gas Generation Rates from FE-3 at $90^{\circ} \mathrm{C}$ and $95^{\circ} \mathrm{C}$

\begin{tabular}{|c|c|c|c|c|c|c|c|c|c|c|c|c|c|c|c|c|c|c|}
\hline \multirow[t]{2}{*}{ Run } & \multirow{2}{*}{$\begin{array}{c}\text { Temp. } \\
{ }^{\circ} \mathrm{C}\end{array}$} & \multicolumn{17}{|c|}{ Gas Generation Rate, moles/kg-day } \\
\hline & & $\mathrm{H}_{2}$ & $\mathrm{CO}_{2}$ & $\mathrm{CH}_{4}$ & $\mathrm{C}_{2} \mathrm{HC}$ & $\mathrm{C}_{>2} \mathrm{HC}$ & $\mathrm{N}_{2}$ & \begin{tabular}{l|l}
$\mathrm{O}_{2}$ \\
\end{tabular} & $\mathrm{Kr} 83$ & $\mathrm{Kr} 84$ & $\mathrm{Kr} 85$ & $\mathrm{Kr} 86$ & Xe 130 & Xe 131 & Xe 132 & Xe 134 & Xe 136 & Time, $\mathrm{h}$ \\
\hline 1 & $\begin{array}{l}90 \\
95 \\
\end{array}$ & $7.88 \mathrm{E}-07$ & $2.66 \mathrm{E}-04$ & $1.7 \mathrm{E}-07$ & $3.4 \mathrm{E}-7$ & $2.8 \mathrm{E}-7$ & $-2.2 \mathrm{E}-05$ & $-1.3 \mathrm{E}-05$ & & & & & & & & & & $\begin{array}{l}327 \\
166 \\
\end{array}$ \\
\hline 2 & 95 & $9.89 \mathrm{E}-07$ & $2.69 \mathrm{E}-04$ & $1.7 \mathrm{E}-07$ & $2.9 \mathrm{E}-7$ & $2.9 \mathrm{E}-7$ & $3.8 \mathrm{E}-06$ & $-2.5 \mathrm{E}-06$ & & & & & & & & & & 477 \\
\hline
\end{tabular}

Table A.15. Gas Generation Rates from FE-5 at $90^{\circ} \mathrm{C}$ and $95^{\circ} \mathrm{C}$

\begin{tabular}{|c|c|c|c|c|c|c|c|c|c|c|c|c|c|c|c|c|c|c|}
\hline \multirow[t]{2}{*}{ Run } & \multirow{2}{*}{$\begin{array}{c}\text { Temp. } \\
{ }^{\circ} \mathrm{C}\end{array}$} & \multicolumn{17}{|c|}{ Gas Generation Rate, moles/kg-day } \\
\hline & & $\mathrm{H}_{2}$ & $\mathrm{CO}_{2}$ & $\mathrm{CH}_{4}$ & $\mathrm{C}_{2} \mathrm{HC}$ & $\mathrm{C}_{>2} \mathrm{HC}$ & $\mathrm{N}_{2}$ & \begin{tabular}{l|l}
$\mathrm{O}_{2}$ & \\
\end{tabular} & Kr 83 & $\mathrm{Kr} 84$ & $\mathrm{Kr} 85$ & $\mathrm{Kr} 86$ & Xe 130 & Xe 131 & Xe 132 & Xe 134 & Xe 136 & Time, $\mathrm{h}$ \\
\hline 1 & $\begin{array}{l}90 \\
95\end{array}$ & $2.62 \mathrm{E}-06$ & $2.76 \mathrm{E}-04$ & $2.3 \mathrm{E}-07$ & $1.7 \mathrm{E}-7$ & $5.8 \mathrm{E}-8$ & $-7.6 \mathrm{E}-06$ & $-3.4 \mathrm{E}-05$ & & & & & & 5.8E-9 & $1.2 \mathrm{E}-8$ & $1.7 \mathrm{E}-8$ & $2.9 \mathrm{E}-8$ & $\begin{array}{l}327 \\
166\end{array}$ \\
\hline 2 & 95 & $3.63 \mathrm{E}-06$ & $2.96 \mathrm{E}-04$ & $3.0 \mathrm{E}-07$ & $1.8 \mathrm{E}-7$ & $1.8 \mathrm{E}-7$ & $7.0 \mathrm{E}-07$ & \begin{tabular}{|l|}
$-5.6 \mathrm{E}-06$ \\
\end{tabular} & & & & & & $3.6 \mathrm{E}-9$ & $5.4 \mathrm{E}-9$ & $6.0 \mathrm{E}-9$ & $1.2 \mathrm{E}-8$ & 476 \\
\hline
\end{tabular}

Table A.16. Gas Generation Rates from FE-4/6 at $90^{\circ} \mathrm{C}$ and $95^{\circ} \mathrm{C}$

\begin{tabular}{|c|c|c|c|c|c|c|c|c|c|c|c|c|c|c|c|c|c|c|}
\hline \multirow[t]{2}{*}{ Run } & \multirow{2}{*}{$\begin{array}{c}\text { Temp. } \\
{ }^{\circ} \mathrm{C}\end{array}$} & \multicolumn{17}{|c|}{ Gas Generation Rate, moles/kg-day } \\
\hline & & $\mathrm{H}_{2}$ & $\mathrm{CO}_{2}$ & $\mathrm{CH}_{4}$ & $\mathrm{C}_{2} \mathrm{HC}$ & $\mathrm{C}_{>2} \mathrm{HC}$ & $\mathrm{N}_{2}$ & \begin{tabular}{l|l}
$\mathrm{O}_{2}$ \\
\end{tabular} & $\mathrm{Kr} 83$ & $\mathrm{Kr} 84$ & $\mathrm{Kr} 85$ & $\mathrm{Kr} 86$ & Xe 130 & $\mathrm{Xe} 131$ & $\mathrm{Xe} 132$ & $\mathrm{Xe} 134$ & Xe 136 & Time, $\mathrm{h}$ \\
\hline 1 & \begin{tabular}{|l|}
90 \\
95
\end{tabular} & $5.29 \mathrm{E}-06$ & $8.11 \mathrm{E}-04$ & $3.5 \mathrm{E}-07$ & $4.9 \mathrm{E}-7$ & $3.5 \mathrm{E}-7$ & $-1.2 \mathrm{E}-05$ & $-1.8 \mathrm{E}-05$ & & & & & $4.2 \mathrm{E}-9$ & $2.1 \mathrm{E}-9$ & 4.9E-9 & $2.8 \mathrm{E}-9$ & $2.1 \mathrm{E}-9$ & $\begin{array}{l}326 \\
160\end{array}$ \\
\hline 2 & 95 & $6.09 \mathrm{E}-06$ & $7.31 \mathrm{E}-04$ & $2.9 \mathrm{E}-07$ & $4.3 \mathrm{E}-7$ & $2.9 \mathrm{E}-7$ & $1.6 \mathrm{E}-06$ & $-4.2 \mathrm{E}-06$ & & & & & & & & & & 477 \\
\hline
\end{tabular}


Table A.17. Gas Analyses for Test $\mathrm{KC}-6$ at $90^{\circ} \mathrm{C}$ and $95^{\circ} \mathrm{C}$

\begin{tabular}{|c|c|c|c|c|c|c|c|c|c|c|c|c|c|c|c|c|c|c|c|c|}
\hline $\begin{array}{c}\text { Run } \\
\text { Sys }-9\end{array}$ & $\begin{array}{c}\text { Temp. } \\
{ }^{\circ} \mathrm{C}\end{array}$ & $\mathrm{Ne}$ & $\mathrm{Ar}$ & $\mathrm{H}_{2}$ & $\mathrm{CO}_{2}$ & $\mathrm{CH}_{4}$ & $\mathrm{C}_{2} \mathrm{HC}$ & $\mathrm{C}_{>2} \mathrm{HC}$ & $\mathrm{N}_{2}$ & $\mathrm{O}_{2}$ & Kr 83 & Kr 84 & $\operatorname{Kr} 85$ & $\mathrm{Kr} 86$ & Xe 130 & Xe 131 & Xe 132 & Xe 134 & Xe 136 & Time, $\mathrm{h}$ \\
\hline \multirow{2}{*}{$\begin{array}{c}1 \\
22 \mathrm{~K} 52 \\
\end{array}$} & \multirow{2}{*}{\begin{tabular}{|l|}
90, \\
95 \\
\end{tabular}} & 92.6 & 0.02 & 0.57 & 5.3 & 0.002 & & 0.001 & 1.3 & 0.138 & & & & & & & & & & \multirow{2}{*}{$\begin{array}{l}327 \\
165 \\
\end{array}$} \\
\hline & & & & 9.71 & 90.2 & 0.03 & & 0.02 & & & & & & & & & & & & \\
\hline \multirow{2}{*}{$\begin{array}{c}2 \\
22 \mathrm{~K} 61\end{array}$} & \multirow[t]{2}{*}{95} & 91.2 & 0.025 & 0.46 & 5.7 & 0.00 & & & 2.10 & 0.44 & & & & & & & & & & \multirow[t]{2}{*}{477} \\
\hline & & & & 7.47 & 92.5 & 0.03 & & & & & & & & & & & & & & \\
\hline
\end{tabular}

Table A.18. Gas Analyses for Test $96-06$ at $80^{\circ} \mathrm{C}$ and $95^{\circ} \mathrm{C}$

\begin{tabular}{|c|c|c|c|c|c|c|c|c|c|c|c|c|c|c|c|c|c|c|c|c|}
\hline $\begin{array}{c}\text { Run } \\
\text { Sys }-10\end{array}$ & $\begin{array}{c}\text { Temp. } \\
{ }^{\circ} \mathrm{C}\end{array}$ & $\mathrm{Ne}$ & $\mathrm{Ar}$ & $\mathrm{H}_{2}$ & $\mathrm{CO}_{2}$ & $\mathrm{CH}_{4}$ & $\mathrm{C}_{2} \mathrm{HC}$ & $\mathrm{C}_{>2} \mathrm{HC}$ & $\mathrm{N}_{2}$ & $\mathrm{O}_{2}$ & $\mathrm{Kr} 83$ & $\mathrm{Kr} 84$ & $\mathrm{Kr} 85$ & $\mathrm{Kr} 86$ & Xe 130 & Xe 131 & Xe 132 & Xe 134 & Xe 136 & Time, $\mathrm{h}$ \\
\hline \multirow{2}{*}{$\begin{array}{c}1 \\
22 \mathrm{~K} 52\end{array}$} & \multirow{2}{*}{$\begin{array}{c}90 \\
95\end{array}$} & 94.4 & 0.021 & 0.10 & 3.6 & 0.005 & 0.005 & 0.003 & 1.52 & 0.31 & $9.0 \mathrm{E}-05$ & $2.0 \mathrm{E}-04$ & $1.0 \mathrm{E}-05$ & $7.0 \mathrm{E}-04$ & & $1.0 \mathrm{E}-03$ & $1.4 \mathrm{E}-03$ & $2.0 \mathrm{E}-03$ & $3.0 \mathrm{E}-03$ & \multirow{2}{*}{$\begin{array}{l}324 \\
147\end{array}$} \\
\hline & & & & 2.56 & 96.9 & 0.13 & 0.13 & 0.081 & & & $2.4 \mathrm{E}-03$ & $5.4 \mathrm{E}-03$ & $2.7 \mathrm{E}-04$ & $1.9 \mathrm{E}-02$ & & $2.7 \mathrm{E}-02$ & $3.8 \mathrm{E}-02$ & \begin{tabular}{|l|}
$5.4 \mathrm{E}-02$ \\
\end{tabular} & \begin{tabular}{|l|}
$8.1 \mathrm{E}-02$ \\
\end{tabular} & \\
\hline \multirow{2}{*}{$\begin{array}{c}2 \\
22 \mathrm{~K} 61\end{array}$} & \multirow[t]{2}{*}{95} & 70.8 & 0.259 & 0.027 & 1.5 & 0.00 & & 0.002 & 21.90 & 5.57 & $6.0 \mathrm{E}-04$ & $1.0 \mathrm{E}-03$ & $1.0 \mathrm{E}-04$ & $1.4 \mathrm{E}-03$ & & $3.5 \mathrm{E}-03$ & $5.9 \mathrm{E}-03$ & 9.2E-03 & $1.4 \mathrm{E}-02$ & \multirow[t]{2}{*}{477} \\
\hline & & & & 1.8 & 95.6 & 0.13 & & 0.13 & & & $3.9 \mathrm{E}-02$ & $6.6 \mathrm{E}-02$ & $6.6 \mathrm{E}-03$ & $9.2 \mathrm{E}-02$ & & $2.3 \mathrm{E}-01$ & $3.9 \mathrm{E}-01$ & $6.0 \mathrm{E}-01$ & 9.2E-01 & \\
\hline
\end{tabular}

Table A.19. Gas Generation Rates from $\mathrm{KC}-6$ at $90^{\circ} \mathrm{C}$ and $95^{\circ} \mathrm{C}$

\begin{tabular}{|c|c|c|c|c|c|c|c|c|c|c|c|c|c|c|c|c|c|c|}
\hline \multirow[t]{2}{*}{ Run } & \multirow{2}{*}{$\begin{array}{c}\text { Temp. } \\
{ }^{\circ} \mathrm{C}\end{array}$} & \multicolumn{17}{|c|}{ Gas Generation Rate, moles/kg-day } \\
\hline & & $\mathrm{H}_{2}$ & $\mathrm{CO}_{2}$ & $\mathrm{CH}_{4}$ & $\mathrm{C}_{2} \mathrm{HC}$ & $\mathrm{C}_{>2} \mathrm{HC}$ & $\mathrm{N}_{2}$ & $\mathrm{O}_{2}$ & $\mathrm{Kr} 83$ & $\mathrm{Kr} 84$ & $\mathrm{Kr} 85$ & $\mathrm{Kr} 86$ & $\mathrm{Xe} 130$ & $\mathrm{Xe} 131$ & $\mathrm{Xe} 132$ & Xe 134 & Xe 136 & Time, $\mathrm{h}$ \\
\hline 1 & \begin{tabular}{|l|}
90 \\
95 \\
\end{tabular} & $3.67 \mathrm{E}-05$ & $3.41 \mathrm{E}-04$ & $1.3 \mathrm{E}-07$ & & $6.4 \mathrm{E}-8$ & $-1.9 \mathrm{E}-05$ & $-1.9 \mathrm{E}-05$ & & & & & & & & & & $\begin{array}{l}327 \\
165 \\
\end{array}$ \\
\hline 2 & 95 & $3.11 \mathrm{E}-05$ & $3.85 \mathrm{E}-04$ & $1.4 \mathrm{E}-07$ & & & $6.3 \mathrm{E}-06$ & $-6.6 \mathrm{E}-06$ & & & & & & & & & & 477 \\
\hline
\end{tabular}

Table A.20. Gas Generation Rates from $96-06$ at $80^{\circ} \mathrm{C}$ and $95^{\circ} \mathrm{C}$

\begin{tabular}{|c|c|c|c|c|c|c|c|c|c|c|c|c|c|c|c|c|c|c|}
\hline \multirow[t]{2}{*}{ Run } & \multirow{2}{*}{$\underset{{ }^{\circ} \mathrm{C}}{\text { Temp. }}$} & \multicolumn{17}{|c|}{ Gas Generation Rate, moles/kg-day } \\
\hline & & $\overline{\mathrm{H}_{2}}$ & $\mathrm{CO}_{2}$ & $\mathrm{CH}_{4}$ & $\mathrm{C}_{2} \mathrm{HC}$ & $\mathrm{C}_{>2} \mathrm{HC}$ & $\mathrm{N}_{2}$ & \begin{tabular}{l|l}
$\mathrm{O}_{2}$ & \\
\end{tabular} & $\mathrm{Kr} 83$ & $\mathrm{Kr} 84$ & $\mathrm{Kr} 85$ & $\mathrm{Kr} 86$ & Xe 130 & $\mathrm{Xe} 131$ & Xe 132 & Xe 134 & Xe 136 & Time, $\mathrm{h}$ \\
\hline 1 & $\begin{array}{l}90 \\
95 \\
\end{array}$ & $5.66 \mathrm{E}-06$ & $2.14 \mathrm{E}-04$ & $3.0 \mathrm{E}-07$ & $3.0 \mathrm{E}-7$ & $1.8 \mathrm{E}-7$ & $-9.1 \mathrm{E}-06$ & $-8.2 \mathrm{E}-06$ & 5.4E-9 & $1.2 \mathrm{E}-8$ & $6.0 \mathrm{E}-10$ & $4.2 \mathrm{E}-8$ & & $6.0 \mathrm{E}-8$ & $8.3 \mathrm{E}-8$ & $1.2 \mathrm{E}-7$ & $1.8 \mathrm{E}-7$ & $\begin{array}{l}324 \\
147 \\
\end{array}$ \\
\hline 2 & 95 & $1.58 \mathrm{E}-06$ & $8.54 \mathrm{E}-05$ & $1.2 \mathrm{E}-07$ & & $1.2 \mathrm{E}-7$ & $1.9 \mathrm{E}-05$ & $-1.3 \mathrm{E}-05$ & $3.5 \mathrm{E}-8$ & $5.9 \mathrm{E}-8$ & 5.9E-9 & $8.2 \mathrm{E}-8$ & & $2.0 \mathrm{E}-7$ & $3.5 \mathrm{E}-7$ & $5.4 \mathrm{E}-7$ & $8.2 \mathrm{E}-7$ & 477 \\
\hline
\end{tabular}




\section{Appendix B}

Estimation of KC-1 Uranium Metal Content on October 7, 1999

(Start of Gas Generation Series I Testing) 
